\title{
AN IRRADIATION TEST OF CANDIDATE HTGR RECYCLE FUELS IN THE H-1 AND H-2 CAPSULES
}
R. A. Olstad
A. R. Olsen
R. B. Fitts
E. L. Long, Jr.
T. B. Lindemer

\section{MASTER}

OAK RIDGE NATIONAL LABORATORY 
Printed in the United States of America. Available from National Technical Information Service

U.S. Department of Commerce

5285 Port Royal Road, Springfield, Virginia 22151

Price: Printed Copy $\$ 5.45$; Microfiche $\$ 1.45$

This report was prepared as an account of work sponsored by the United States Government. Neither the United States nor the United States Atomic Energy Commission, nor any of their employees, nor any of their contractors, subcontractors, or their employees, makes any warranty, express or implied, or assumes any legal liability or responsibility for the accuracy, completeness or usefulness of any information, apparatus, product or process disclosed, or represents that its use would not infringe privately owned rights. 


\section{DISCLAIMER}

This report was prepared as an account of work sponsored by an agency of the United States Government. Neither the United States Government nor any agency Thereof, nor any of their employees, makes any warranty, express or implied, or assumes any legal liability or responsibility for the accuracy, completeness, or usefulness of any information, apparatus, product, or process disclosed, or represents that its use would not infringe privately owned rights. Reference herein to any specific commercial product, process, or service by trade name, trademark, manufacturer, or otherwise does not necessarily constitute or imply its endorsement, recommendation, or favoring by the United States Government or any agency thereof. The views and opinions of authors expressed herein do not necessarily state or reflect those of the United States Government or any agency thereof. 


\section{DISCLAIMER}

Portions of this document may be illegible in electronic image products. Images are produced from the best available original document. 


\section{AN IRRADIATION TEST OF CANDIDATE HTGR RECYCLE FUELS IN THE H-1 AND H-2 CAPSULES}

R. A. Olstad

R. B. Fitts

A. R. Olsen E. L. Long, Jr.

T. B. Lindemer

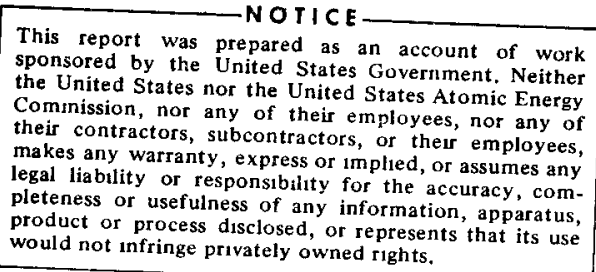

\section{JULY 1974}

NOTICE This document contains information of a preliminary nature and was prepared primarily for internal use at the Oak Ridge National Laboratory. It is subject to revision or correction and therefore does not represent a final report.

OAK RIDGE NATIONAL LABORATORY

Oak Ridge, Tennessee $\mathbf{3 7 8 3 0}$

operated by

UNION CARBIDE CORPORATION

for the

U.S. ATOMIC ENERGY COMMISSION 
○

: 


\section{CONTENTS}

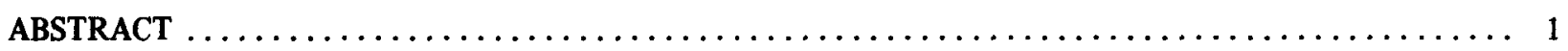

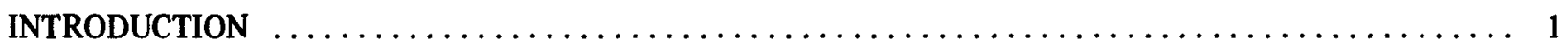

DESCRIPTION OF FUEL SAMPLES AND CAPSULES $\ldots \ldots \ldots \ldots \ldots \ldots \ldots \ldots \ldots \ldots \ldots \ldots \ldots \ldots \ldots$

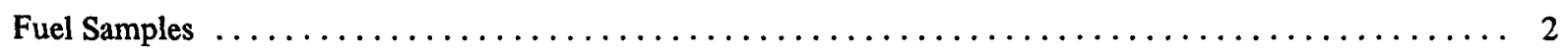

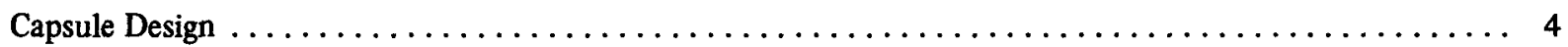

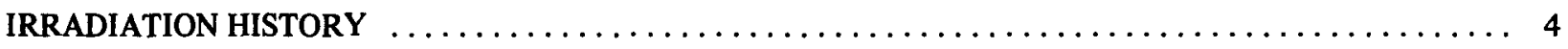

CALCULATED AND MEASURED EXPERIMENTAL PARAMETERS $\ldots \ldots \ldots \ldots \ldots \ldots \ldots \ldots \ldots \ldots$

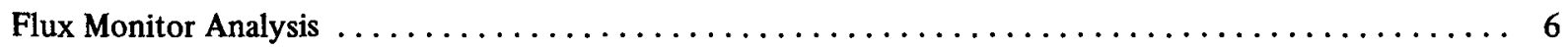

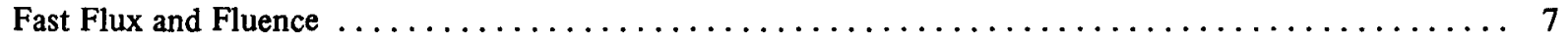

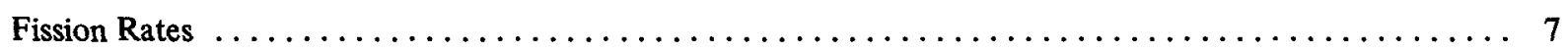

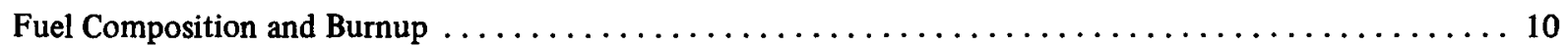

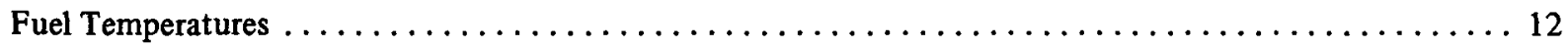

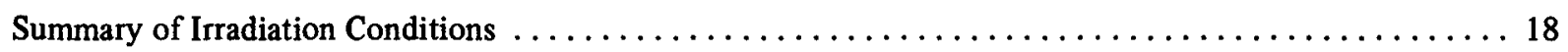

POSTIRRADIATION EXAMINATION OF FUEL SAMPLES $\ldots \ldots \ldots \ldots \ldots \ldots \ldots \ldots \ldots \ldots \ldots \ldots \ldots$

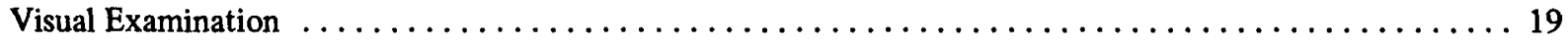

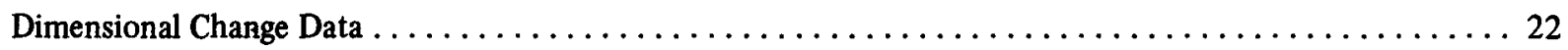

Metallography of Fuel Rods That Operated at Normal Temperatures

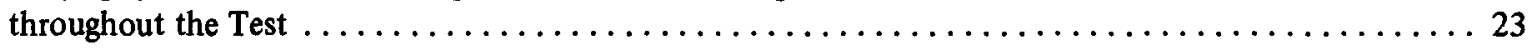

Metallography of Fuel Samples That Operated at Very High Temperatures during

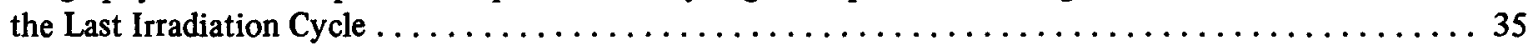

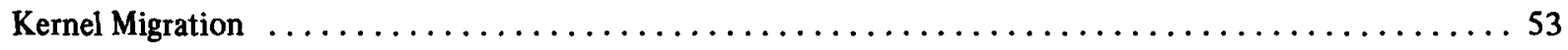

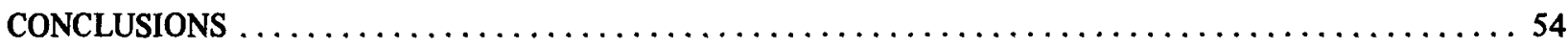

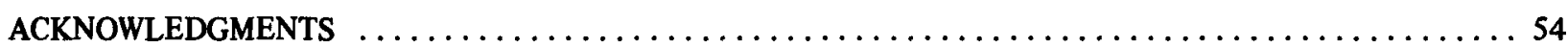

APPENDIX: Details of the Calculation of Experimental Parameters $\ldots \ldots \ldots \ldots \ldots \ldots \ldots \ldots \ldots \ldots \ldots$

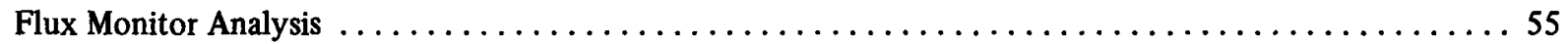

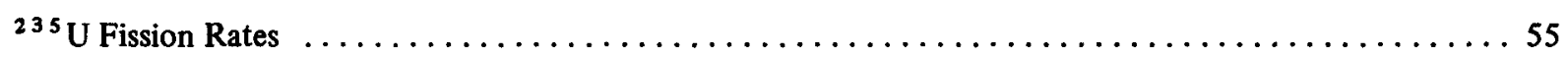

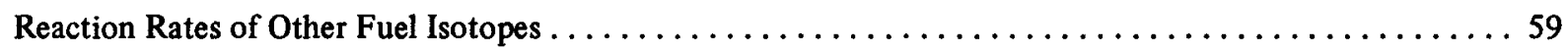




\title{
AN IRRADIATION TEST OF CANDIDATE HTGR RECYCLE FUELS IN THE H-1 AND H-2 CAPSULES
}

\author{
R. A. Olstad A. R. Olsen R. B. Fitts \\ E. L. Long, Jr. T. B. Lindemer ${ }^{1}$
}

\begin{abstract}
Coated HTGR fuel particles were irradiated under severe thermal conditions to high fast fluences ( 2 to $6 \times 10^{21}$ neutrons $/ \mathrm{cm}^{2},>0.18 \mathrm{MeV}$ ) and burnups ( 25 to $45 \%$ uranium burnup, $<1 \%$ thorium burnup) in the ETR in the H-1 and H-2 capsule irradiation test from May 1971 to May 1972 . The test was designed to provide samples of irradiated fuel rods for head-end reprocessing studies and to give an accelerated irradiation of the reference recycle fuel particles that are currently being irradiated in the Peach Bottom Reactor in the Recycle Test Element series. Bonded rods of Biso-coated $\mathrm{UO}_{2}$, $(4.1 \mathrm{Th}, \mathrm{U}) \mathrm{O}_{2},(2.2 \mathrm{Th}, \mathrm{U}) \mathrm{O}_{2}$ or uranium-loaded strong-acid ion-exchange-resin particles mixed with Biso-coated $\mathrm{ThO}_{2}$ particles and rods of Triso-coated $\mathrm{UC}_{2}$ mixed with Biso-coated $\mathrm{ThC}_{2}$ particles were irradiated. The initial fissile isotope was ${ }^{235} \mathrm{U}$ in all samples. The coated particles were bonded in a close-packed configuration with a carbonaceous matrix to form rods approximately $1 / 2 \mathrm{in}$. in diameter $\times 2$ in. long. Each capsule was surrounded by a hafnium sieeve to decrease the thermal flux in the fuel. About half the samples operated at much above design temperatures during the last of the four irradiation cycles because the capsules were inadvertently irradiated in an inverted position during this period. The calculated center-line temperatures of the bonded rods varied from 900 to $1500^{\circ} \mathrm{C}$ at the beginning of the test and from 600 to $2600^{\circ} \mathrm{C}$ at the beginning of the last cycle. Postirradiation examination showed that the rods that operated at normal temperatures throughout the test were largely fragmented or debonded, possibly because of high thermal gradients or because of repeated thermal cycling during the test. The particles themselves survived the irradiation in excellent condition. A small amount of kernel migration was observed in $\mathrm{UO}_{2},(4.1 \mathrm{Th}, \mathrm{U}) \mathrm{O}_{2}$, and $(2.2 \mathrm{Th}, \mathrm{U}) \mathrm{O}_{2}$ particles in normal-temperature rods but was not observed in the $\mathrm{ThO}_{2}$ particles. The rods that operated at very high temperatures during the last cycle were severely damaged and contained a central region of reddish powder with no recognizable particles remaining. Substantial migration of the mixed oxide and $\mathrm{UO}_{2}$ kernels as well as the $\mathrm{ThO}_{2}$ kernels was observed. None of the carbide or resin-derived particles have been examined metallographically at the time of writing.
\end{abstract}

\section{INTRODUCTION}

The fuel being considered for use in commercial High-Temperature Gas-Cooled Reactors (HTGR's) consists of coated particles of thorium oxide or carbide, uranium oxide or carbide, and mixtures of thorium and uranium oxides or carbides. The particle configuration in the Biso design consists of a fuel kernel coated successively with a low-density carbon buffer layer and a high-density isotropic pyrolytic carbon layer. The Triso design is essentially a Biso particle coated with a silicon carbide layer and an additional high-density pyrolytic carbon layer to improve fission product retention. The particles are bonded into rods with a carbonaceous matrix.

The irradiation performance of the fuel is determined by the response of the coated particles and matrix material to the operating conditions of temperature, burnup, and fast neutron fluence. All these parameters affect the stresses that develop in the particle coatings. The fast neutron fluence is a particularly important parameter because of the irradiation-induced dimensional changes and irradiation-enhanced creep that occur in the pyrolytic carbon coatings. ${ }^{2}$ Particle coatings must be designed to accommodate these irradiation-induced changes without coating failures.

The main objectives of the H-1 and H-2 capsule irradiation test in the Engineering Test Reactor (ETR) were to provide samples of irradiated HTGR recycle-type fuel rods $^{3}$ for head-end reprocessing studies and

1. Chemical Technology Division.

2. J. C. Bokros and D. W. Stevens, "Irradiation Behavior of Isotropic Carbons," Carbon 9:19 (1971).

3. Oak Ridge National Laboratory, Gulf General Atomic, and Idaho Chemical Processing Plant, National HTGR Fuel Recycle Development Program Plan, ORNL-4702, Rev. 1, in publication. 
to determine the irradiation performance of these fuel rods in an accelerated test. An important aspect of the test was to evaluate the performance of mixed-oxide particles coated in prototype production-scale coaters. The H-1 and H-2 test was also intended to give fuel performance data in advance of the Recycle Test Elements ${ }^{4}$ (RTE's), which contain the same types of fuel as the H-capsules and are currently undergoing nonaccelerated tests in the Peach Bottom Reactor.

Various aspects of the purpose, design, and postirradiation examination of the H-capsules have been reported previously. ${ }^{5-7}$ The tests were designed so that the coated particles would be irradiated to approximately full HTGR design fast neutron fluence in about six months, as compared to irradiation times of about four years for fuels in 1160-MW(e) HTGR's. Hafnium or hafnium-zirconium thermal neutron shrouds surrounded each capsule to reduce the thermal flux and therefore the heating rate in the particles. The samples were designed to operate at different temperatures depending on the flux level at the axial position of the sample and on the width of the gap between the capsule and the tapered graphite sleeve around the samples. The capsules were designed so that all fuel samples would operate with center-line temperatures below $1600^{\circ} \mathrm{C}$. However, temperatures greater than $2000^{\circ} \mathrm{C}$ were attained in some of the fuel samples because the capsules were inadvertently irradiated in an inverted position during the last of four irradiation cycles. The samples that operated at very high temperatures during the last irradiation cycle were severely damaged. The inverted operation greatly complicated the determination of fuel sample temperatures, burnups, and fast neutron fluences. The analysis was also complicated because of the difficulty in determining the effect of the hafnium-zirconium thermal neutron shrouds that surrounded the capsules.

The particle types tested included Triso-coated $\mathrm{UC}_{2}$ and Biso-coated $(4.1 \mathrm{Th}, \mathrm{U}) \mathrm{O}_{2},(2.2 \mathrm{Th}, \mathrm{U}) \mathrm{O}_{2}, \mathrm{UO}_{2}$, $\mathrm{ThO}_{2}, \mathrm{ThC}_{2}$, and uranium-loaded strong-acid ion-exchange-resin kernels (UOS). The initial fissile isotope was ${ }^{235} \mathrm{U}$ (93\% enrichment) in all samples. All the fuels were irradiated in the form of 0.5-in.-diam intrusion-bonded rods. The (4.1Th, $\mathrm{U}) \mathrm{O}_{2}, \mathrm{UO}_{2}$, and $\mathrm{ThO}_{2}$ particles were also irradiated as loose particles in blended beds. Metallography was performed on irradiated rods containing oxide and mixed-oxide kernels. Metallographic data on the rods containing carbide particles will be reported when available.

\section{DESCRIPTION OF FUEL SAMPLES AND CAPSULES}

\section{Fuel Samples}

Each capsule contained 13 fuel samples, denoted H-1-1 through H-1-13 and H-2-1 through H-2-13. The distribution of particle types was the same for both capsules. All samples were intrusion-bonded rods except for samples 6 and 13, which consisted of loose particles. Each sample contained a blend of fissile and fertile particles as shown in Table 1. A detailed description of the particles is given in Table 2 . The relative proportion of fissile and fertile particles in each rod was adjusted so that the initial weight of ${ }^{235} \mathrm{U}$ was approximately $0.191 \mathrm{~g}$ per inch of rod length.

4. E. L. Long, Jr., R. B. Fitts, and F. J. Homan, Fabrication of ORNL Fuel Irradiated in the Peach Bottom Reactor and Postirradiation Examination of Recycle Test Elements 7 and 4, ORNL-TM-4477 (in press).

5. A. R. Olsen and R. B. Fitts, "Capsule Tests," Gas-Cooled Reactor and Thorium Utilization Programs Annu. Progr. Rep. Sept. 30, 1971, ORNL-4760, pp. 67-68.

6. A. R. Olsen and R. B. Fitts, "ETR Capsules H-1 and H-2," ORNL Programs Annu. Progr. Rep. for period Oct. 1, 1971-Dec. 31, 1972, ORNL-4911, pp. 116-24.

7. R. A. Olstad, R. B. Fitts, A. R. Olsen, and E. L. Long, Jr., "Capsule Irradiation Tests," Metals and Ceramics Div. Annu. Progr. Rep. June 30, 1973, ORNL-4870, pp. 72-74. 
Table 1. H-1 and H-2 fuel description

\begin{tabular}{|c|c|c|c|c|c|}
\hline Particle combination & $\mathbf{a}$ & c & f & g & $\mathbf{R}$ \\
\hline $\begin{array}{l}\text { Bonded rod numbers } \\
\text { Loose particle bed } \\
\text { number }\end{array}$ & $\begin{array}{l}4,10 \\
6\end{array}$ & 3,11 & $1,5,9$ & $\begin{array}{l}2,12 \\
13\end{array}$ & 7,8 \\
\hline Fissile particle & $(4.1 \mathrm{Th}, \mathrm{U}) \mathrm{O}_{2}$ & $(2.2 \mathrm{Th}, \mathrm{U}) \mathrm{O}_{2}$ & $\mathrm{UC}_{2}$ & $\mathrm{UO}_{2}$ & Resin UOS \\
\hline Coating & Biso & Biso & Triso & Biso & Biso \\
\hline Batch & PR-57 & PR-67 & GGA-4000-312 & OR-1370 & OR-1462 \\
\hline Fertile particle & $\mathrm{ThO}_{2}$ & $\mathrm{ThO}_{2}$ & $\mathrm{ThC}_{2}$ & $\mathrm{ThO}_{2}$ & $\mathrm{ThO}_{2}$ \\
\hline Coating & Biso & Biso & Biso & Biso & Biso \\
\hline Batch & OR-1365 & OR-1365 & 9T-980-BL & OR-1365 & OR-1365 \\
\hline Th:U ratio in mix & 13.9 & 14.4 & 10.2 & 16.1 & 14.9 \\
\hline
\end{tabular}

Table 2. Detailed particle description

\begin{tabular}{|c|c|c|c|c|c|c|c|}
\hline Batch & PR-57 & PR 67 & OR-1370 & OR-1462 & OR-1365 & 9T-980-BL & GGA-4000-312 \\
\hline \multicolumn{8}{|l|}{ Kernel } \\
\hline Composition & $(4.1 \mathrm{Th}, \mathrm{U}) \mathrm{O}_{2}$ & $(2.2 \mathrm{Th}, \mathrm{U}) \mathrm{O}_{2}$ & $\mathrm{UO}_{2}$ & Resin UOS & $\mathrm{ThO}_{2}$ & $\mathrm{ThC}_{2}$ & $\mathrm{UC}_{2}$ \\
\hline Diameter, $\mu \mathrm{m}$ & 355 & 353 & $114^{\circ}$ & 340 & 450 & 387 & \\
\hline Std. dev., ${ }^{a} \mu \mathrm{m}$ & 30 & 41 & 11 & 65 & 35 & 38 & \\
\hline Enrichment, $\%{ }^{235} \mathrm{U}$ & 92.9 & 93.2 & 93.2 & 90.1 & & & 93.1 \\
\hline \multicolumn{8}{|l|}{ Buffer coating } \\
\hline Density, $\mathrm{g} / \mathrm{cm}^{3}$ & 1.10 & 1.15 & & & & & \\
\hline Thickness, $\mu \mathrm{m}$ & 80 & 78 & 53 & 43 & 47 & 48 & \\
\hline Std. dev. ${ }^{a} \mu \mathrm{m}$ & 15 & 17 & & 4 & 14 & 6 & \\
\hline \multicolumn{8}{|l|}{$\operatorname{LTI}^{b}$ coating } \\
\hline Gradient density, ${ }^{c} \mathrm{~g} / \mathrm{cm}^{3}$ & 1.93 & 1.85 & $1.89-1.95$ & 1.88 & 1.85 & 1.88 & \\
\hline Corrected ${ }^{d}$ & 1.85 & 1.71 & & & & & \\
\hline Bulk density, ${ }^{e} \mathrm{~g} / \mathrm{cm}^{3}$ & 1.84 & 1.73 & & & & & \\
\hline Bacon anisotropy factor & $<1.1$ & $<1.1$ & & & & & \\
\hline Thickness, $\mu \mathrm{m}$ & 135 & 142 & 70 & 63 & 73 & 73 & \\
\hline Std. dev. ${ }^{a} \mu \mathrm{m}$ & & & & 7 & 5 & 8 & \\
\hline Coating rate, $\mu \mathrm{m} / \mathrm{min}$ & 7.7 & 8.3 & 2.9 & 9.0 & 8.6 & & \\
\hline Particle density, $\mathrm{g} / \mathrm{cm}^{3}$ & 2.48 & 2.27 & 2.06 & 1.81 & 3.95 & 3.15 & 2.07 \\
\hline
\end{tabular}

${ }^{a}$ Where data on dimensions were quoted as minimum, average, and maximum values, the standard deviation was defined as $(\max -\min ) / 4$, so that the maximum and minimum values are approximately two standard deviations from the average.

${ }^{b}$ Low temperature isotropic.

${ }^{c}$ As measured in a gradient density column.

${ }^{d}$ Corrected for the penetration of gradient-density liquid into the coating porosity open to the surface. This open porosity was determined to be 3.9 and $7.5 \%$ of the LTI coating volume for batches PR-57 and PR-67, respectively. These values were determined from the carbon content and the particle densities as measured with a mercury pycnometer using pressures of 250 and 10,000 psi.

${ }^{\ell}$ Calculated from carbon content and 250 -psi mercury pycnometer density measurements.

The oxide kernels were made at ORNL by the sol-gel process. ${ }^{8}$ The mixed oxide particles were coated at ORNL in a 5-in.ID prototype production-scale coater, whereas the $\mathrm{UO}_{2}, \mathrm{ThO}_{2}$, and $\mathrm{UOS}$ particles were coated in a small-scale laboratory coater. The buffer coatings were all deposited from acetylene diluted with helium. The high-density pyrocarbon coatings were all low temperature isotropic (LTI) deposited from propene gas. The $\mathrm{UC}_{2}$ and $\mathrm{ThC}_{2}$ coated particles were supplied by Gulf General Atomic.

8. Paul A. Haas, Sol-Gel Preparation of Spheres: Design and Operation of Fluidized Bed Columns, ORNL-4398 (September 1969). 
The fuel rods were made at ORNL by an intrusion-bonding technique ${ }^{9}$ with 35 wt \% Poco AXZ graphite filler ${ }^{10}$ in $15 \mathrm{~V}$ pitch binder. ${ }^{11}$ All bonded rods were approximately 0.5 in. in diameter $\times 2.1$ in. long except for the UOS particle rods, which were approximately $0.5 \mathrm{in}$. long. The loose particle beds 6 and 13 were 0.9 and $2.2 \mathrm{in.}$ long, respectively, and $0.5 \mathrm{in}$. in diameter.

The samples were separated from each other by graphite plugs approximately $0.5 \mathrm{in}$. long. In addition each graphite plug was separated from the fuel samples by a $1 / 8$-in. carbon felt insulator. Flux monitor wires ( $\mathrm{Ti}, \mathrm{Fe}, \mathrm{Ni}$, and type 302 stainless steel) were contained in stainless steel capsules in five of the graphite plugs in each capsule.

\section{Capsule Design}

A schematic of the H-capsule design is shown in Fig. 1. Each capsule consisted of a bottom sleeve (containing samples 1 through 7) and a top sleeve (containing samples 8 through 13). The H-327 graphite ${ }^{12}$ sleeves had an inner diameter of $0.501 \mathrm{in}$. The outer surfaces of the graphite sleeves were tapered to provide a variable gap between the sleeve and the type 304 stainless steel capsule. The gaps between the fuel and the graphite sleeve and between the graphite sleeve and the stainless steel initially contained helium at atmospheric pressure. The bottom and top sections of each capsule were surrounded by hafnium and $\mathrm{Zr}-40 \% \mathrm{Hf}$ thermal neutron shrouds ${ }^{13}$ respectively. The shrouds were designed to decrease the thermal flux levels in the fuel and to flatten the axial thermal flux profile.

The temperature of each fuel sample was governed by the corresponding width of the graphitestainless-steel gap, the composition of the thermal neutron shroud, the thermal flux levels at the axial position of the sample, the fuel composition, and the thermal conductivities of the shroud, stainless steel, helium, graphite sleeve, and fuel sample. At the time the experiment was designed, the estimated initial fuel center-line temperatures in the bottom and top sections of the $\mathrm{H}-1$ capsule were 1050 and $1300^{\circ} \mathrm{C}$, respectively, and 950 and $750^{\circ} \mathrm{C}$ in the bottom and top sections, respectively, of the H-2 capsule. The differences in design temperatures between the two capsules were due to different graphite-sleevestainless-steel gap widths. Calculations made using better estimates of bonded rod thermal conductivity and gamma and fission heating rates gave initial temperatures several hundred degrees higher than the design values.

\section{IRRADIATION HISTORY}

The H-1 and $\mathrm{H}-2$ capsules were irradiated in the J-8 position of the ETR core during the four reactor cycles 112 through 115. The capsules began their irradiation in May 1971 and were removed in May 1972. The irradiation of the capsules was interrupted during cycles 112 and 114 because of reactor power oscillations observed by ETR personnel. ${ }^{14}$ In an effort to determine the cause of the oscillations, ETR personnel removed the H-2 capsule for a portion of cycle 112, and both capsules were removed for most of cycle 114. Evidence shows that when the capsules were returned to the reactor for cycle 115, they were inadvertently inverted. The flux monitor data taken during each cycle in positions near the capsules indicate that the inversion indeed occurred at the beginning of cycle 115 and not at some prior time.

9. J M Robbins and J. H. Coobs, "Development of Bonded Beds of Coated Particles for HTGR Fuel Elements," GCR Program Semiannu. Progr. Rep. Mar. 31, 1970, ORNL-4589, pp. 10-13.

10. Graphite flour supplied by Poco Graphite, Inc.

11. Grade $15 \mathrm{~V}$ coal tar pitch supplied by Applied Chemical Company.

12. H-327 graphite supplied by Great Lakes Carbon Corp.

13. Hafnium-zirconium alloys supplied by Bettis Atomic Power Laboratory.

14. E. E. Burdick and J. L. Liebenthal, ETR Power-Variation Analysis, ANCR-1085 (August 1972). 
ORNL-DWG 70-4728R2

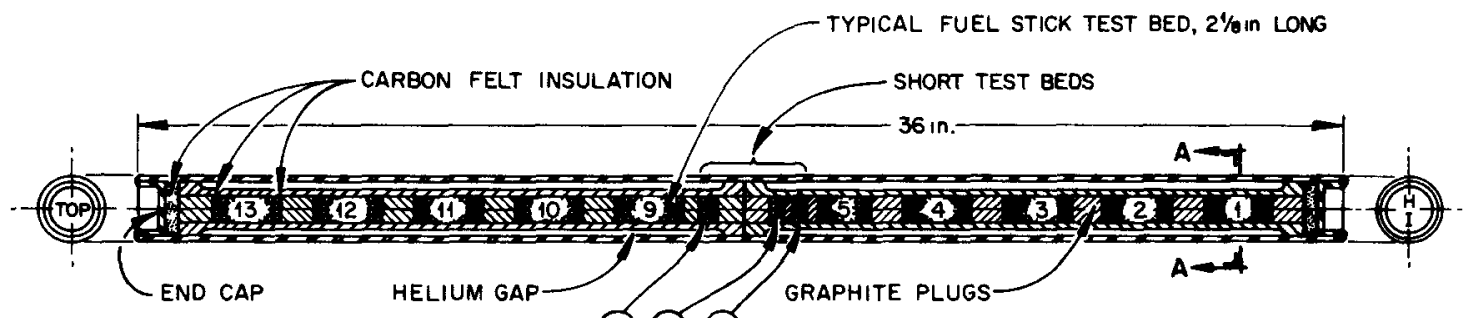

(8) (7) (6)

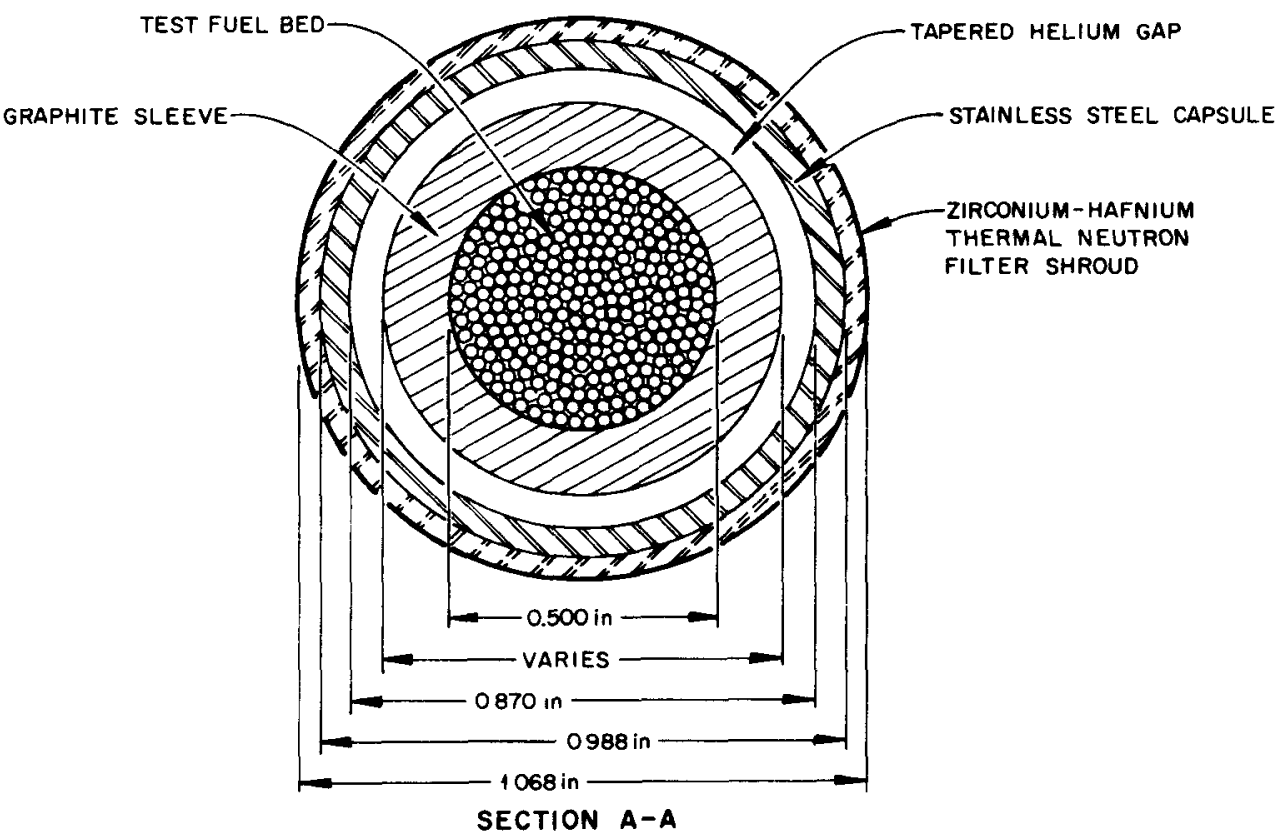

Fig. 1. Schematic of the $\mathrm{H}-1$ and $\mathrm{H}-2$ capsules.

The detailed power history of the ETR during the irradiation test is shown in Fig. 2. Both capsules were in the reactor for the whole power history shown, except that the $\mathrm{H}-2$ capsule was not irradiated during cycles $112 \mathrm{D}$ and E. The power history shown in Fig. 2 can be reduced to show that the H-1 and H.2 capsules operated for 39.3 equivalent full power days (EFPD) in an inverted position as compared to their total of 136.4 and 124.9 EFPD, respectively. The power history was very erratic in that the reactor was frequently shut down and was rapidly cycled numerous times during tests to determine the cause of the power variations.

Approximately half the fuel samples operated at significantly higher flux levels and temperatures during the last cycle than at the beginning of the test. Center-line temperatures greater than $2000^{\circ} \mathrm{C}$ have been calculated for the rods in the highest neutron flux regions at the start of the last cycle. These high temperatures are consistent with the severe degradation that was observed for some of the rods in postirradiation examination.

The peak unperturbed thermal flux $(2200 \mathrm{~m} / \mathrm{sec})$ and fast flux $(>1 \mathrm{MeV})$ measured in the $\mathrm{J}-8$ position of the ETR during a previous cycle (107B) were 4.6 and $3.8 \times 10^{14}$ neutrons $\mathrm{cm}^{-2} \mathrm{sec}^{-1}$, respectively. The fast flux $(>0.18 \mathrm{MeV})$ was estimated to be approximately $7 \times 10^{14}$ neutrons $\mathrm{cm}^{-2} \mathrm{sec}^{-1}$. These flux levels are an order of magnitude larger than the flux levels in a 1160-MW(e) HTGR, for which the thermal 


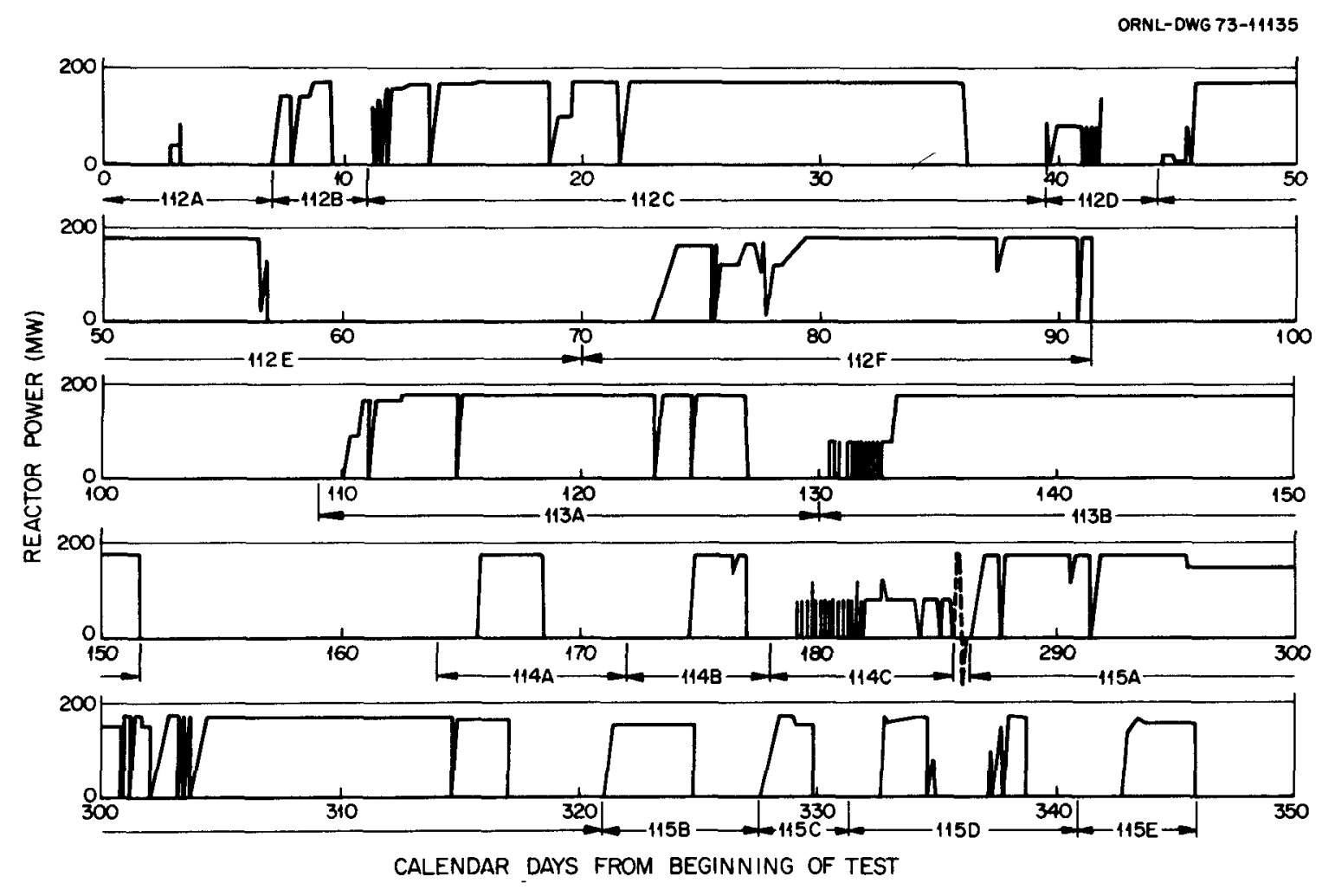

Fig. 2. ETR power history during $H-1$ and $H-2$ irradiation test.

flux and fast flux $(>0.18 \mathrm{MeV})$ are ${ }^{15}$ each approximately $4 \times 10^{13}$ neutrons $\mathrm{cm}^{-2} \mathrm{sec}^{-1}$. The fluxes measured during cycle 107B are the "unperturbed" fluxes measured in the absence of the $\mathrm{H}-1$ and $\mathrm{H}-2$ capsules. These fluxes would have been approximately the flux values in the $\mathrm{H}-1$ and $\mathrm{H}-2$ capsules if no hafnium-zirconium shrouds had been used, assuming that the ETR core configuration was the same during cycle 107B as during cycles 112 through 115. The hafnium-zirconium shrouds were designed to reduce the thermal flux roughly by a factor of 2.5 to restrict the fission heat rate to manageable levels. The shrouds have little effect on the fast flux, so the particle coatings could still achieve high fast neutron fluences in a much shorter time than in an HTGR. However, because of the shrouds, the burnup of ${ }^{235} \mathrm{U}$ and especially that of ${ }^{232}$ Th were considerably lower than those obtained at a comparable fast fluence in an HTGR.

\section{CALCULATED AND MEASURED EXPERIMENTAL PARAMETERS}

\section{Flux Monitor Analysis}

The small stainless steel capsules containing the $\mathrm{Fe}, \mathrm{Ni}, \mathrm{Ti}$, and type 302 stainless steel flux monitor wires were embedded in the graphite plugs at the bottom, between rods 3 and 4 , at the center, between rods 10 and 11 , and at the top of the capsules. The wires between rods 10 and 11 in both capsules were not recovered after the irradiation because the small capsules containing the wires had melted. The capsule from

15. K. P. Steward, "Objectives and Plans for Fuel Testing in the Peach Bottom HTGR," Proceedings of Gas-Cooled Reactor Information Meeting at Oak Ridge National Laboratory A pril 27-30, 1970, CONF-700401, pp. 63-90. 
H-1 had completely melted, while that from $\mathrm{H}-2$ had only partially melted, indicating that the temperature of these capsules during the last irradiation cycle was at least $1130^{\circ} \mathrm{C}$ (the iron-carbon eutectic melting point). The other flux monitor wires were analyzed to determine the fast and thermal fluxes during the irradiation, as discussed in the Appendix. The analysis was complicated by the inversion of the capsules since the flux levels before and after inversion were substantially different.

\section{Fast Flux and Fluence}

The fast neutron flux and fluence in the fuel samples were determined both from the flux monitor wires irradiated in the capsules and from measurements of the fast flux $(>1 \mathrm{MeV})$ made by ETR personnel at three radial positions near the capsule at various axial positions during each irradiation cycle. For a neutron energy spectrum characteristic of the ETR core, the fast flux $(>0.18 \mathrm{MeV})$ is approximately 1.9 times the fast flux $(>1 \mathrm{MeV})$. This factor was used in both methods to determine the fast flux and fluence $(>0.18 \mathrm{MeV})$. Calculations with the XSDRN computer code ${ }^{16}$ showed that the fast flux is not significantly attenuated by the hafnium shrouds, so the fast flux in the capsule should be the same as the fast flux measured outside the capsules. The fast flux and fluence as determined from flux monitor analysis and from the fast flux measured outside the capsules are given in Tables 3 and 4 and Fig. 3. The values of total fluence determined by the two methods are in agreement within $30 \%$, which is considered satisfactory. The total fast fluence attained in the fuel samples varied from 2.2 to $6.5 \times 10^{21}$ neutrons $/ \mathrm{cm}^{2}(>0.18 \mathrm{MeV})$, based on the flux measured outside the capsules. The maximum fast fluence obtained was therefore approximately $80 \%$ of the maximum 1160-MW(e) HTGR design fast fluence of $8 \times 10^{21}$ neutrons $/ \mathrm{cm}^{2}$.

\section{Fission Rates}

The effect of the hafnium-zirconium shrouds and other capsule components on the fission and neutron absorption rates in the various fuel isotopes was calculated using the XSDRN and ANISN $^{17}$ computer codes. The calculations were normalized so that the calculated ${ }^{235} \mathrm{U}$ fission rates at the beginning of the test agreed within $10 \%$ with the fission rates measured in ${ }^{235} \mathrm{U}$ fission monitors irradiated in mockup capsules in the ETR Critical Facility (see Appendix Table A-2). The fission rates were measured with the mockup capsules in their proper orientation and the ETR core in the configuration existing during cycles 112 and 114.

The ETR Critical Facility has nearly the same fuel loading and core configuration as the ETR, but is run at much lower power levels. The mockup capsules $\mathrm{HC}-1$ and $\mathrm{HC}-2$ were almost identical to the $\mathrm{H}-1$ and $\mathrm{H}-2$ capsules and were surrounded by identical hafnium-zirconium shrouds. The fuel samples in the mockup capsules consisted of loose particles rather than bonded rods, and the fission monitors were located in a 0.25-in.-diam hole in the center of the fuel beds. Only $(4.1 \mathrm{Th}, \mathrm{U}) \mathrm{O}_{2}$ and $\mathrm{ThC}_{2}$ particles were irradiated in the ETR Critical Facility, but the fissile loading ( $\mathrm{g}^{235} \mathrm{U} / \mathrm{in}$.) was the same as in the $\mathrm{H}-1$ and $\mathrm{H}-2$ fuel samples.

The assumptions made in determining the fission rates at each axial position are described in detail in the Appendix. The best estimate of the axial profiles of ${ }^{235} \mathrm{U}$ fission rate before and after the capsule inversion are shown in Fig. 4. These profiles were determined from the profiles of thermal flux measured

16. N. M. Greene and C. W. Craven, Jr., XSDRN: A Discrete Ordinates Spectral Averaging Code, ORNL-TM-2500 (July 1969).

17. W. W. Engle, Jr., A User's Manual for ANISN, a One Dimensional Discrete Ordinates Transport Code with Anisotropic Scattering, K-1693 (March 1967). 
Table 3. Comparison of fast neutron flux and total fluence as determined from flux monitor analysis and as measured outside of the capsules

\begin{tabular}{|c|c|c|c|c|c|c|c|}
\hline \multirow{3}{*}{$\begin{array}{l}\text { Location of } \\
\text { flux monitor }\end{array}$} & \multicolumn{4}{|c|}{ Fast flux $(>0.18 \mathrm{MeV})$ (neutrons $\mathrm{cm}^{-2} \mathrm{sec}^{-1}$ ) } & \multirow{2}{*}{\multicolumn{2}{|c|}{$\begin{array}{c}\text { Total fast fluence }(>0.18 \mathrm{MeV}) \\
\text { (neutrons } / \mathrm{cm}^{2} \text { ) }\end{array}$}} & \multirow{3}{*}{ Ratio $^{a}$} \\
\hline & \multicolumn{2}{|c|}{ Before inversion } & \multicolumn{2}{|c|}{ After inversion } & & & \\
\hline & $\begin{array}{l}\text { Based on flux } \\
\text { monitors }\end{array}$ & $\begin{array}{l}\text { Based on flux } \\
\text { outside capsules }\end{array}$ & $\begin{array}{l}\text { Based on flux } \\
\text { monitors }\end{array}$ & $\begin{array}{l}\text { Based on flux } \\
\text { outside capsules }\end{array}$ & $\begin{array}{l}\text { Based on flux } \\
\text { monitors }\end{array}$ & $\begin{array}{l}\text { Based on flux } \\
\text { outside capsules }\end{array}$ & \\
\hline H-1 Top & $1.25 \times 10^{14}$ & $0.8 \times 10^{14}$ & $3.35 \times 10^{14}$ & $3.8 \times 10^{14}$ & $2.1 \times 10^{21}$ & $2.0 \times 10^{21}$ & 1.05 \\
\hline H-1 Center & 5.65 & 5.1 & 3.1 & 5.0 & 5.7 & 6.0 & 0.95 \\
\hline H-1 Between rods 3 and 4 & 6.2 & 5.9 & 1.4 & 3.0 & 5.7 & 6.1 & 0.93 \\
\hline H-1 Bottom & 2.25 & 3.7 & 1.2 & 0.4 & 2.3 & 3.2 & 0.72 \\
\hline H-2 Top & 1.6 & 0.8 & 2.4 & 3.8 & 2.0 & 1.9 & 1.05 \\
\hline H-2 Center & 3.8 & 5.6 & 5.4 & 5.0 & 4.5 & 5.5 & 0.82 \\
\hline H-2 Between rods 3 and 4 & 4.0 & 5.9 & 3.15 & 3.0 & 4.0 & 5.6 & 0.71 \\
\hline H-2 Bottom & 2.0 & 3.7 & 1.35 & 0.4 & 1.9 & 2.8 & 0.68 \\
\hline
\end{tabular}

${ }^{a}$ Ratio of total fast fluence based on flux monitors to that based on flux measured outside the capsules. 
Table 4. Total fast neutron fluence as estimated from the fast flux measured outside the capsules

\begin{tabular}{rll}
\hline & \multicolumn{2}{c}{$\begin{array}{c}\text { Fast neutron fluence } \\
(>0.18 \mathrm{MeV}) \\
\text { Sample }\end{array}$} \\
\cline { 2 - 3 } (neutrons/cm $\left.{ }^{2}\right)$ \\
\hline Capsule H-1 & Capsule H-2 \\
\hline 1 & $3.9 \times 10^{21}$ & $3.4 \times 10^{21}$ \\
2 & 5.0 & 4.5 \\
3 & 5.8 & 5.2 \\
4 & 6.3 & 5.8 \\
5 & 6.5 & 5.9 \\
6 & 6.3 & 5.8 \\
7 & 6.1 & 5.6 \\
8 & 5.9 & 5.4 \\
9 & 5.8 & 5.2 \\
10 & 5.4 & 5.0 \\
11 & 4.5 & 4.1 \\
12 & 3.6 & 3.4 \\
13 & 2.5 & 2.3 \\
\hline
\end{tabular}

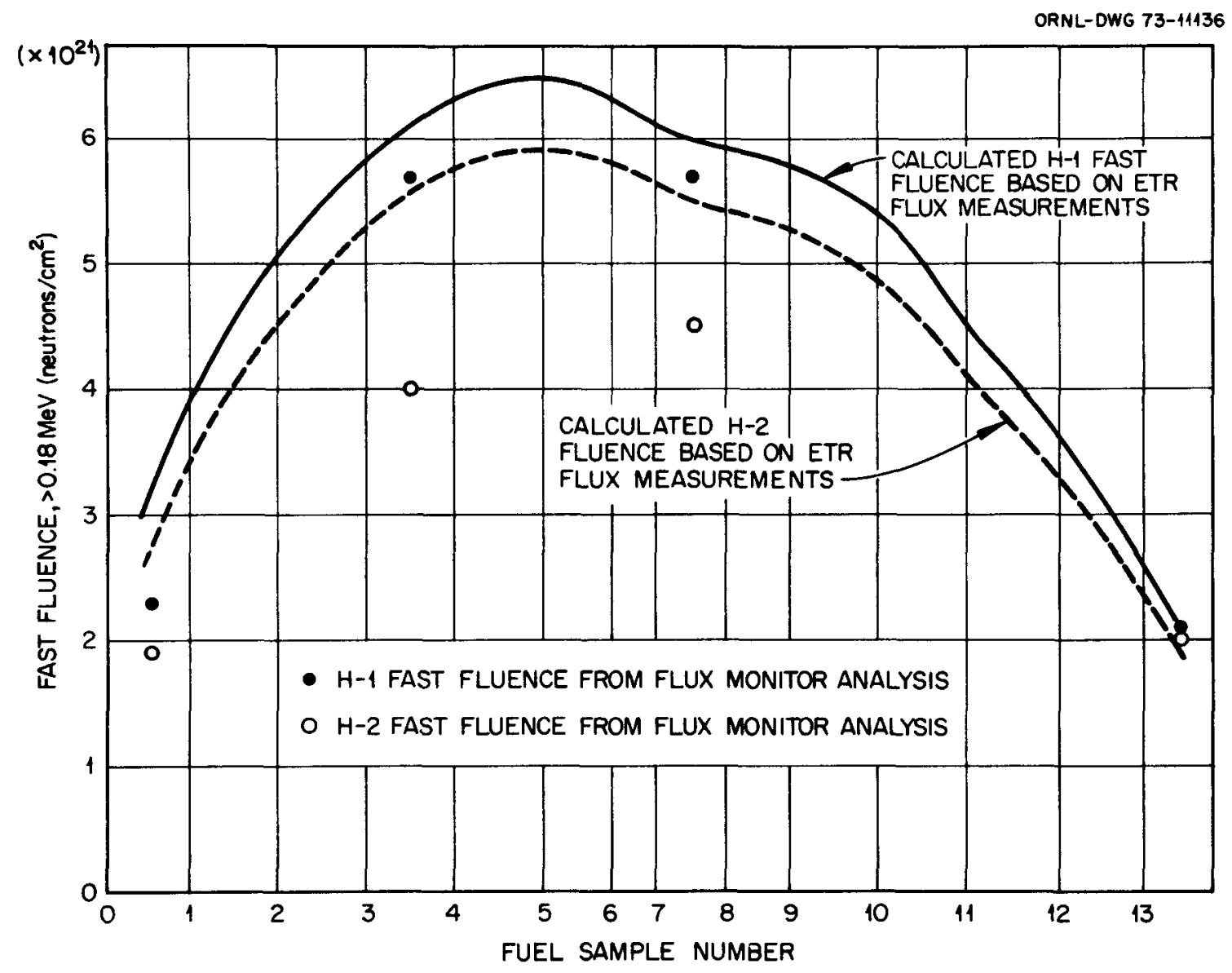

Fig. 3. Fast fluence in $\mathbf{H}-1$ and $\mathbf{H}-2$ fuel samples. 


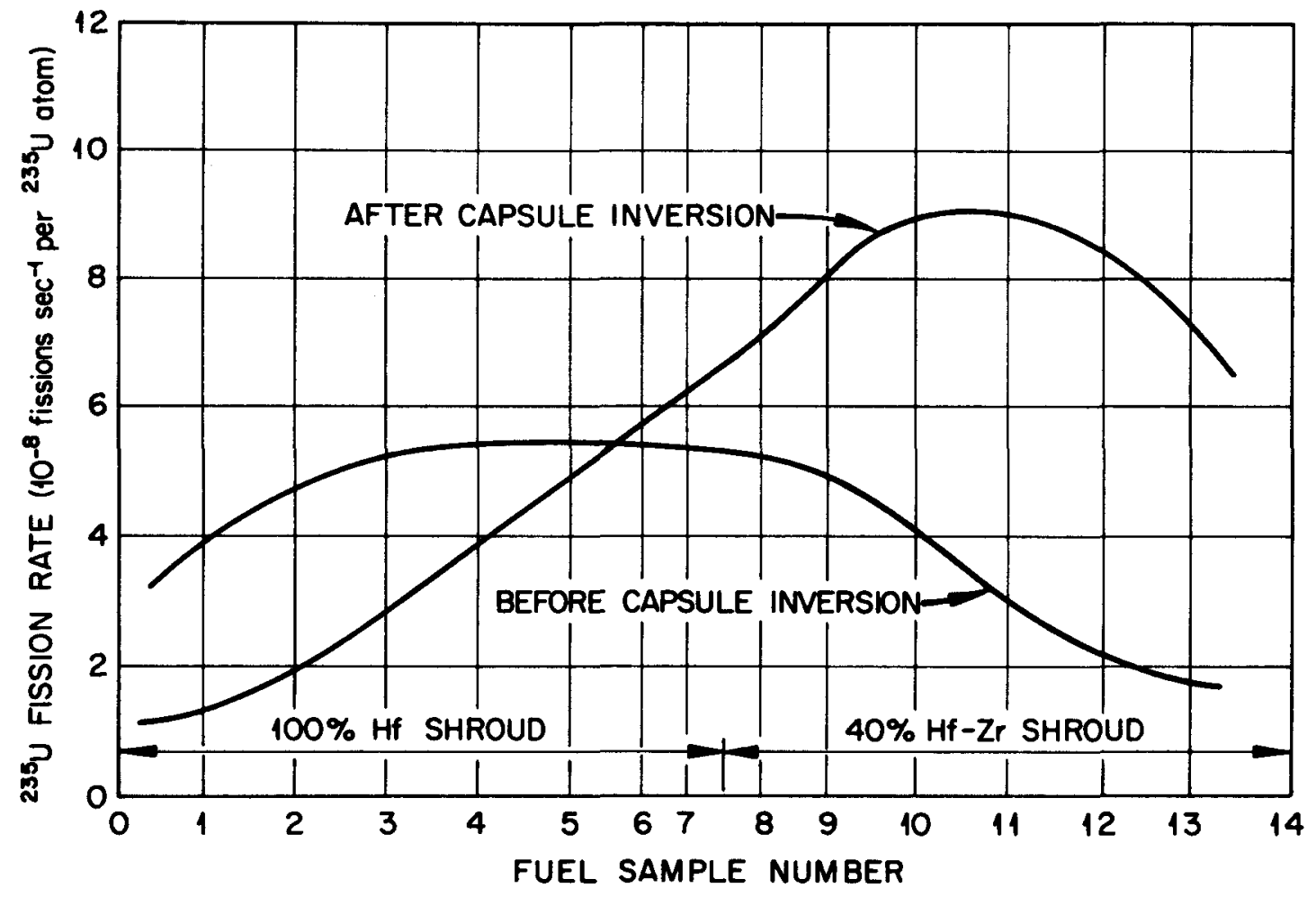

Fig. 4. Fission rate of ${ }^{235} \mathrm{U}$ in $\mathrm{H}$ capsules before and after the capsule inversion.

outside the capsules during each cycle by ETR personnel and were normalized to the ETR Critical Facility data. In the top section of the capsules, the ${ }^{235} \mathrm{U}$ fission rates (fissions $\sec ^{-1} \operatorname{per}^{235} \mathrm{U}$ atom) were roughly 3 times as large after the capsule inversion as before. Similarly, the ${ }^{235} \mathrm{U}$ fission rates in the bottom section of the capsules were much lower during the last cycle than during the first three cycles. It was this large increase in ${ }^{235} \mathrm{U}$ fission rate (or equivalently, the thermal flux) in the top section of the capsule that caused very high operating temperatures and subsequent damage to the fuel during the last irradiation cycle.

\section{Fuel Composition and Burnup}

The compositions of the fuel samples at various times during the irradiation test were calculated by numerically solving the nuclear transformation equations. The initial fuel compositions, reactor power history, and fission and neutron absorption rates at full reactor power are the data needed to perform the calculations. The main changes in the fuel sample compositions during the irradiation are because of fission and neutron capture in ${ }^{235} \mathrm{U}$, neutron absorption by ${ }^{232} \mathrm{Th}$ to form ${ }^{233} \mathrm{~Pa}$, decay of ${ }^{233} \mathrm{~Pa}$ to ${ }^{233} \mathrm{U}$, and fission and neutron capture of ${ }^{233} \mathrm{U}$. Of particular importance are the initial composition (to determine the initial heating rates), the composition at the beginning of the last cycle (to determine the effect of inverting the capsules on the heating rates), and the composition at the end of the test (to determine the final burnup in each fuel sample).

The fission and neutron absorption rates for the various fuel isotopes were calculated with the XSDRN code, as described in the Appendix. The linear fission heat rates and burnup of heavy metal that were obtained in these calculations are given in Tables 5 and 6 respectively. The small differences of these results 
Table 5. Calculated linear fission heat rates during the irradiation

\begin{tabular}{|c|c|c|c|c|c|c|c|c|}
\hline \multirow{3}{*}{ Sample } & \multicolumn{8}{|c|}{ Linear fission heat rate $(\mathrm{kW} / \mathrm{ft})$} \\
\hline & \multicolumn{2}{|c|}{$\begin{array}{l}\text { Beginning } \\
\text { of cycle } 112\end{array}$} & \multicolumn{2}{|c|}{$\begin{array}{c}\text { End of } \\
\text { cycle } 114\end{array}$} & \multicolumn{2}{|c|}{$\begin{array}{c}\text { Beginning } \\
\text { of cycle } 115\end{array}$} & \multicolumn{2}{|c|}{$\begin{array}{c}\text { End of } \\
\text { cycle } 115\end{array}$} \\
\hline & $\mathrm{H}-1$ & $\mathrm{H}-2$ & $\mathrm{H}-1$ & $\mathrm{H}-2$ & H-1 & $\mathrm{H}-2$ & $\mathbf{H}-1$ & H-2 \\
\hline 1 & 6.6 & 6.6 & 5.0 & 5.1 & 1.7 & 1.8 & 1.7 & 1.7 \\
\hline 2 & 8.0 & 8.0 & 6.2 & 6.3 & 2.5 & 2.5 & 2.4 & 2.4 \\
\hline 3 & 9.0 & 9.0 & 6.7 & 6.8 & 4.0 & 4.0 & 3.7 & 3.7 \\
\hline 4 & 9.2 & 9.2 & 6.8 & 6.9 & 5.0 & 5.2 & 4.6 & 4.7 \\
\hline 5 & 9.2 & 9.2 & 6.3 & 6.6 & 6.0 & 6.2 & 5.1 & 5.3 \\
\hline 6 & 9.2 & 9.2 & 6.8 & 6.9 & 7.6 & 7.8 & 6.5 & 6.7 \\
\hline 7 & 8.6 & 8.6 & 6.5 & 6.6 & 8.1 & 8.3 & 6.9 & 7.0 \\
\hline 8 & 8.8 & 8.8 & 6.4 & 6.6 & 8.8 & 9.0 & 7.3 & 7.5 \\
\hline 9 & 8.3 & 8.3 & 5.8 & 6.0 & 9.7 & 10.0 & 7.6 & 7.9 \\
\hline 10 & 6.9 & 6.9 & 5.3 & 5.5 & 12.2 & 12.5 & 9.5 & 9.7 \\
\hline 11 & 5.1 & 5.1 & 4.2 & 4.3 & 13.0 & 13.3 & 10.1 & 10.2 \\
\hline 12 & 3.6 & 3.6 & 3.2 & 3.2 & 12.6 & 12.8 & 10.0 & 10.1 \\
\hline 13 & 2.9 & 2.9 & 2.6 & 2.7 & 11.0 & 11.1 & 9.0 & 9.1 \\
\hline
\end{tabular}

Table 6. Calculated burnup obtained in the H-1 and $\mathbf{H}-2$ fuel samples

\begin{tabular}{|c|c|c|c|c|c|c|c|c|}
\hline \multirow{3}{*}{ Sample } & \multirow{3}{*}{$\begin{array}{c}\text { Fissile } \\
\text { particle }\end{array}$} & \multirow{3}{*}{$\begin{array}{c}\text { Fertile } \\
\text { particle }\end{array}$} & \multicolumn{6}{|c|}{ Burnup (\% FIMA) } \\
\hline & & & \multicolumn{2}{|c|}{ Thorium $^{a}$} & \multicolumn{2}{|c|}{ Uranium $^{b}$} & \multicolumn{2}{|c|}{$\begin{array}{l}\text { In fissile } \\
\text { particle }^{c}\end{array}$} \\
\hline & & & $\mathrm{H}-1$ & $\mathbf{H}-2$ & $\mathrm{H}-1$ & $\mathrm{H}-2$ & $\mathrm{H}-1$ & $\mathrm{H}-2$ \\
\hline 1 & $\mathrm{UC}_{2}$ & $\mathrm{ThC}_{2}$ & 0.15 & 0.13 & 28 & 26 & 28 & 26 \\
\hline 2 & $\mathrm{UO}_{2}$ & $\mathrm{ThO}_{2}$ & 0.23 & 0.19 & 33 & 31 & 33 & 31 \\
\hline 3 & $(2.2 \mathrm{Th}, \mathrm{U}) \mathrm{O}_{2}$ & $\mathrm{ThO}_{2}$ & 0.31 & 0.26 & 37 & 35 & 12 & 11 \\
\hline 4 & $(4.1 \mathrm{Th}, \mathrm{U}) \mathrm{O}_{2}$ & $\mathrm{ThO}_{2}$ & 0.37 & 0.31 & 40 & 37 & 8.2 & 7.5 \\
\hline 5 & $\mathrm{UC}_{2}$ & $\mathrm{ThC}_{2}$ & 0.42 & 0.36 & 41 & 39 & 41 & 39 \\
\hline 6 & (4.1Th,U)O & $\mathrm{ThO}_{2}$ & 0.45 & 0.38 & 42 & 40 & 8.6 & 8.2 \\
\hline 7 & UOS resin & $\mathrm{ThO}_{2}$ & 0.46 & 0.39 & 42 & 39 & 42 & 39 \\
\hline 8 & UOS resin & $\mathrm{ThO}_{2}$ & 0.43 & 0.37 & 43 & 41 & 43 & 41 \\
\hline 9 & $\mathrm{UC}_{2}$ & $\mathrm{ThC}_{2}$ & 0.42 & 0.36 & 44 & 42 & 44 & 42 \\
\hline 10 & $(4.1 \mathrm{Th}, \mathrm{U}) \mathrm{O}_{2}$ & $\mathrm{ThO}_{2}$ & 0.37 & 0.32 & 42 & 41 & 8.6 & 8.3 \\
\hline 11 & $(2.2 \mathrm{Th}, \mathrm{U}) \mathrm{O}_{2}$ & $\mathrm{ThO}_{2}$ & 0.27 & 0.24 & 38 & 37 & 12 & 12 \\
\hline 12 & $\mathrm{UO}_{2}$ & $\mathrm{ThO}_{2}$ & 0.19 & 0.17 & 34 & 32 & 34 & 32 \\
\hline 13 & $\mathrm{UO}_{2}$ & $\mathrm{ThO}_{2}$ & 0.13 & 0.12 & 29 & 28 & 29 & 28 \\
\hline
\end{tabular}

${ }^{a} 100 \times$ number of ${ }^{233} \mathrm{U}$ fissions per initial ${ }^{232} \mathrm{Th}$ atom.

$b_{100} \times$ number of ${ }^{235} \mathrm{U}$ and $\mathrm{Pu}$ fissions per initial $\mathrm{U}$ atom.

${ }^{c} 100 \times$ number of total fissions per initial heavy metal atom in fissile particle.

between the $\mathrm{H}-1$ and $\mathrm{H}-2$ capsules exist because the $\mathrm{H}-2$ capsule was irradiated 11.5 fewer days during cycle 112. In addition to the fission heat rate, each sample had a gamma heat rate of approximately $1 \mathrm{~kW} / \mathrm{ft}$. The total linear heat rate in the fuel samples therefore varied from 4 to $10 \mathrm{~kW} / \mathrm{ft}$ at the beginning of the irradiation and from 3 to $14 \mathrm{~kW} / \mathrm{ft}$ at the beginning of the last irradiation cycle. Some of the rods therefore operated at considerably higher linear heat rates both before and after the capsule inversion than the maximum linear heat rate of $7 \mathrm{~kW} / \mathrm{ft}$ expected ${ }^{\mathbf{1 8}}$ in fuel rods with a $50 \%$ larger cross-sectional area in a 1160-MW(e) HTGR.

18. Delmarva Power and Light Company, Preliminary Safety Analysis Report for the Summit Power Station, Docket Nos. 50-450 and 50-451 (1973), Table 4.4.2-3. 
The calculated burnup of uranium in the fuel samples varies from 25 to $45 \%$ FIMA, which is considerably less than the maximum uranium burnup of about $75 \%$ expected in a 1160 -MW(e) HTGR. The approximately $0.5 \%$ FIMA burnup of thorium calculated for the $\mathrm{H}-1$ and $\mathrm{H}-2$ fuel samples is very much less than the 7\% FIMA burnup of thorium expected in a commercial HTGR. Similarly, the total burnup of approximately $8 \%$ FIMA calculated for the $(4.1 \mathrm{Th}, \mathrm{U}) \mathrm{O}_{2}$ particles is considerably less than the $20 \%$ FIMA expected $^{19}$ for this kernel composition in an HTGR.

\section{Fuel Temperatures}

The temperatures in the fuel samples were calculated by a program ${ }^{20}$ called GENGTC, which solves the one-dimensional heat conduction equations in cylindrical geometry. The input parameters include the room-temperature geometry, thermal expansion coefficients and thermal conductivities of all capsule components as functions of temperature, surface emissivities, fission heat rate, and gamma heat rate. The gamma heat rate was taken as $15 \mathrm{~W}$ per gram of material in all calculations. This was based on the gamma heat rate of from 5 to $19 \mathrm{~W}$ per gram of graphite that was measured at various axial locations in the J-8 position of the ETR during cycle 101.

As shown in Fig. 5, the surface temperature of a fuel sample is a strong function of the fission heat rate and of the gap widths between the stainless steel and the graphite sleeve and between the fuel and the

19. K. P. Steward, "Objectives and Plans for Fuel Testing in the Peach Bottom HTGR," Proceedings of Gas-Cooled Reactor Information Meeting at Oak Ridge National Laboratory April 27-30, 1970, CONF-700401, pp. 63-90.

20. H. C. Roland, GENGTC, a One-Dimensional CEIR Computer Program for Capsule Temperature Calculations in Cylindrical Geometry, ORNL-TM-1942 (December 1967).

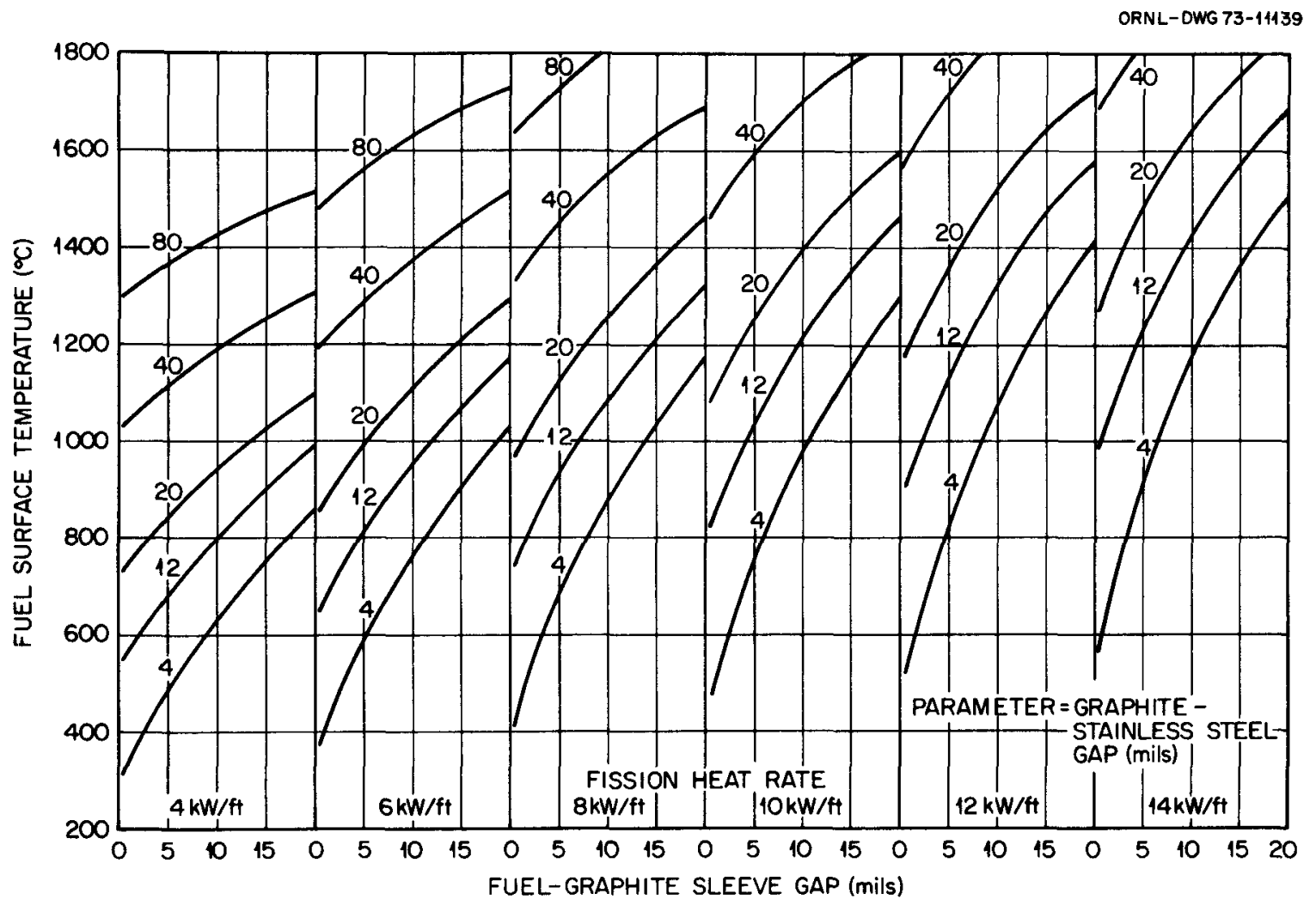

Fig. 5. Calculated fuel sample surface temperature as a function of linear fission heat rate and gap widths. 
graphite sleeve. If the fission heat rate and gap widths are known, the surface temperature of a rod can be determined. Assuming that the heat generation within a rod is uniform and that the thermal conductivity is constant across the rod, the temperature profile within a rod is parabolic and is given by:

$$
T(r)=T_{s}+\frac{Q}{4 \pi K}\left(\frac{r_{s}^{2}-r^{2}}{r_{s}^{2}}\right)
$$

where

$$
\begin{aligned}
T_{S} & =\text { surface temperature of the sample, }{ }^{\circ} \mathrm{C} ; \\
T(r) & =\text { temperature at radius } r,{ }^{\circ} \mathrm{C} ; \\
Q & =\text { fission plus gamma linear heat rate in the fuel, } \mathrm{W} / \mathrm{cm} ; \\
K & =\text { thermal conductivity of the fuel sample, } \mathrm{W} \mathrm{cm}-1{ }^{\circ} \mathrm{C}^{-1} ; \\
r_{s} & =\text { outer radius of the fuel sample. }
\end{aligned}
$$

For a gamma heat rate of $15 \mathrm{~W} / \mathrm{g}$, the center-line temperature becomes:

$$
T(0)=T_{s}+[2.61 \times(\mathrm{kW} / \mathrm{ft})+2.72] / K
$$

where

$$
T(0)=\text { center-line temperature, }{ }^{\circ} \mathrm{C} ;
$$

$(\mathrm{kW} / \mathrm{ft})=$ linear fission heat rate.

Differentiating Eq. (1) with respect to $r$ shows that the temperature gradient within a rod varies linearly from zero at its center to the maximum at the rod surface. The average temperature gradient along a radius is the gradient at $r_{s} / 2$ and is equal to one-half the maximum temperature gradient:

$$
\left(\frac{d T}{d r}\right)_{\mathrm{av}}=\left[T_{s}-T(0)\right] / r_{s}=1 / 2\left(\frac{d T}{d r}\right)_{\max }
$$

where

$(d T / d r)_{\mathrm{av}}=$ radial average temperature gradient in a rod $=$ gradient at $r_{s} / 2 ;$

$(d T / d r)_{\max }=$ maximum temperature gradient in a rod $=$ gradient at $r_{s}$.

The surface temperatures, center-line temperatures, and average temperature gradients calculated for the fuel samples are given in Table 7 at the beginning of the first irradiation cycle, at the end of the third cycle, and at the beginning and end of the last cycle, during which the capsules were inverted. The gap widths assumed in these temperature calculations are given in Table 8 . The calculated center-line temperatures of the bonded rods vary from 820 to $1470^{\circ} \mathrm{C}$ at the beginning of the test and from 640 to $2570^{\circ} \mathrm{C}$ at the beginning of the irradiation in the inverted position. The initial temperatures were comparable with the temperatures expected in a 1160-MW(e) HTGR, for which the nominal maximum design temperature ${ }^{21}$ is $1420^{\circ} \mathrm{C}$. However, the temperatures of rods 9 through 12 after the capsules were

21. Delmarva Power and Light Company, Preliminary Safety Analysis Report for the Summit Power Station, Docket Nos. 50-450 and 50-451 (1973), Table 4.4.2-3. 
Table 7. Calculated temperatures and temperature gradients in the $\mathrm{H}-1$ and $\mathbf{H}-2$ fuel samples

\begin{tabular}{|c|c|c|c|c|c|c|c|c|c|c|c|c|}
\hline \multirow[b]{2}{*}{ Sample } & \multicolumn{3}{|c|}{ Beginning of cycle $112^{a}$} & \multicolumn{3}{|c|}{ End of cycle $114^{b}$} & \multicolumn{3}{|c|}{ Beginning of cycle $115^{b}$} & \multicolumn{3}{|c|}{ End of cycle $115^{b}$} \\
\hline & $\begin{array}{l}T_{s} \\
\left({ }^{\circ} \mathrm{C}\right)\end{array}$ & $\begin{array}{l}T(0) \\
\text { ("C) }\end{array}$ & $\begin{array}{c}(d T / d r)_{\mathrm{av}} \\
\left.{ }^{\circ} \mathrm{C} / \mathrm{cm}\right)\end{array}$ & $\stackrel{T_{s}}{\left.{ }^{\circ} \mathrm{C}\right)}$ & $\begin{array}{l}T(0) \\
\left.{ }^{\circ} \mathrm{C}\right)\end{array}$ & $\begin{array}{c}(d T / d r)_{\mathrm{av}} \\
\left({ }^{\circ} \mathrm{C} / \mathrm{cm}\right)\end{array}$ & $\begin{array}{c}T_{s} \\
\left({ }^{\circ} \mathrm{C}\right)\end{array}$ & $\begin{array}{l}T(0) \\
\left.{ }^{\circ} \mathrm{C}\right)\end{array}$ & $\begin{array}{c}(d T / d r)_{\mathrm{av}} \\
\left({ }^{\circ} \mathrm{C} / \mathrm{cm}\right)\end{array}$ & $\stackrel{T_{s}}{\left({ }^{\circ} \mathrm{C}\right)}$ & $\begin{array}{l}T(0) \\
\left.{ }^{\circ} \mathrm{C}\right)\end{array}$ & $\begin{array}{c}(d T / d r)_{\mathrm{av}} \\
(\mathrm{C} / \mathrm{cm})\end{array}$ \\
\hline H-1-1 & 660 & 950 & 460 & 770 & 1070 & 470 & 510 & 650 & 220 & 510 & 650 & 220 \\
\hline H-1-2 & 820 & 1160 & 540 & 890 & 1250 & 570 & 620 & 800 & 280 & 610 & 780 & 270 \\
\hline H-1 -3 & 930 & 1310 & 600 & 980 & 1370 & 610 & 790 & 1040 & 390 & 760 & 1000 & 380 \\
\hline H-1 4 & 1030 & 1420 & 610 & 1030 & 1420 & 610 & 900 & 1200 & 470 & 870 & 1150 & 440 \\
\hline H-1-5 & 1070 & 1460 & 610 & 1020 & 1390 & 580 & 1010 & 1360 & 550 & 940 & 1250 & 490 \\
\hline$H-1-6^{c}$ & 900 & 1670 & 1210 & 970 & 1560 & 930 & 1000 & 1650 & 1020 & 940 & 1510 & 900 \\
\hline H-1-7 & 1110 & 1470 & 570 & 1100 & 1480 & 600 & 1230 & 1690 & 720 & 1140 & 1540 & 630 \\
\hline H-1-8 & 780 & 1150 & 580 & 830 & 1200 & 580 & 970 & 1460 & 770 & 890 & 1310 & 660 \\
\hline H-1-9 & 800 & 1150 & 550 & 860 & 1200 & 540 & 1180 & 1720 & 850 & 1050 & 1480 & 680 \\
\hline H-1-10 & 1080 & 1380 & 470 & 940 & 1260 & 500 & 1480 & 2150 & 1060 & 1320 & 1850 & 830 \\
\hline H-1-11 & 1070 & 1300 & 360 & 1050 & 1310 & 410 & 1680 & 2390 & 1120 & 1510 & 2070 & 880 \\
\hline H-1-12 & 1050 & 1230 & 280 & 1070 & 1280 & 330 & 1880 & 2570 & 1090 & 1710 & 2270 & 880 \\
\hline$H-1-13^{c}$ & 1190 & 1490 & 470 & 1180 & 1450 & 430 & 1880 & 2790 & 1430 & 1750 & 2510 & 1200 \\
\hline H-2-1 & 570 & 860 & 460 & 720 & 1030 & 490 & 500 & 640 & 220 & 490 & 630 & 220 \\
\hline $\mathrm{H}-2-2$ & 720 & 1060 & 540 & 830 & 1200 & 580 & 570 & 750 & 280 & 560 & 730 & 270 \\
\hline H-2-3 & 970 & 1350 & 600 & 910 & 1300 & 610 & 720 & 970 & 390 & 700 & 940 & 380 \\
\hline H-2-4 & 1040 & 1430 & 610 & 940 & 1340 & 630 & 820 & 1130 & 490 & 790 & 1080 & 460 \\
\hline H-2.5 & 1010 & 1400 & 610 & 970 & 1350 & 600 & 940 & 1300 & 570 & 880 & 1200 & 500 \\
\hline$H-2-6^{c}$ & 920 & 1690 & 1210 & 890 & 1490 & 940 & 940 & 1610 & 1050 & 880 & 1460 & 910 \\
\hline H-2-7 & 1100 & 1460 & 570 & 1010 & 1390 & 600 & 1130 & 1600 & 740 & 1040 & 1440 & 630 \\
\hline H-2-8 & 700 & 1070 & 580 & 790 & 1170 & 600 & 910 & 1410 & 790 & 830 & 1260 & 680 \\
\hline H-2-9 & 720 & 1070 & 550 & 780 & 1130 & 550 & 1000 & 1560 & 880 & 900 & 1350 & 710 \\
\hline H-2-10 & 800 & 1100 & 470 & 750 & 1080 & 520 & 1120 & 1800 & 1070 & 980 & 1520 & 850 \\
\hline H-2-11 & 740 & 970 & 360 & 700 & 970 & 420 & 1190 & 1910 & 1130 & 1040 & 1610 & 900 \\
\hline H-2-12 & 640 & 820 & 280 & 640 & 850 & 330 & 1350 & 2050 & 1100 & 1210 & 1770 & 880 \\
\hline $\mathrm{H}-2-13^{c}$ & 760 & 1060 & 470 & 760 & 1040 & 440 & 1340 & 2260 & 1450 & 1220 & 1980 & 1200 \\
\hline
\end{tabular}

${ }^{a}$ Assuming bonded rod thermal conductivity of $0.07 \mathrm{~W} \mathrm{~cm}^{-1}{ }^{\circ} \mathrm{C}^{-1}$, loose bed conductivity of $0.035 \mathrm{~W} \mathrm{~cm}^{-1}{ }^{\circ} \mathrm{C}^{-1}$, with gaps at their initial values.

${ }^{b}$ Assuming bonded rod thermal conductivity of $0.05 \mathrm{~W} \mathrm{~cm}^{-1}{ }^{\circ} \mathrm{C}^{-1}$, loose bed conductivity of $0.035 \mathrm{~W} \mathrm{~cm}^{-1}{ }^{\circ} \mathrm{C}^{-1}$, with graphite-sleeve-stainless-steel gaps at their postirradiation values and fuel-graphite sleeve gaps all at 5 mils except 0.5 mil for loose beds.

${ }^{c}$ Loose bed of particles.

Table 8. Gap widths used in the temperature calculations

\begin{tabular}{|c|c|c|c|c|c|c|c|c|c|}
\hline \multirow{3}{*}{ Sample } & \multicolumn{4}{|c|}{ Graphite-stainless-steel gap (mils) } & \multicolumn{5}{|c|}{ Fuel-graphite gap (mils) } \\
\hline & \multicolumn{2}{|c|}{ Initial } & \multicolumn{2}{|c|}{ Final $^{a}$} & \multicolumn{2}{|c|}{ Initial } & \multicolumn{2}{|c|}{$\begin{array}{c}\text { Final } \\
\text { "measured" } b\end{array}$} & \multirow{2}{*}{$\begin{array}{l}\text { Final used } \\
\text { in temp. calc }\end{array}$} \\
\hline & H-1 & $\mathrm{H}-2$ & H-1 & $\mathrm{H}-2$ & $\mathrm{H}-1$ & $\mathrm{H}-2$ & $\mathrm{H}-1$ & $\mathrm{H}-2$ & \\
\hline 1 & 6.8 & 4.1 & 13.0 & 11.0 & 4 & 4 & 9 & 9 & 5 \\
\hline 2 & 8.5 & 6.5 & 15.0 & 12.3 & 5 & 5 & & 9 & 5 \\
\hline 3 & 10.3 & 8.9 & 17.0 & 13.9 & 5 & 7 & & 11 & 5 \\
\hline 4 & 12.1 & 11.2 & 19.0 & 15.4 & 6 & 7 & 7 & 13 & 5 \\
\hline 5 & 13.6 & 13.5 & 20.6 & 17.0 & 6 & 4 & & & 5 \\
\hline 6 & 15.2 & 15.5 & 22.4 & 18.5 & 0.5 & 0.5 & & & 0.5 \\
\hline 7 & 16.0 & 16.6 & 23.5 & 19.4 & 6 & 5 & & & 5 \\
\hline 8 & 4.5 & 3.8 & 12.0 & 10.2 & 6 & 5 & & & 5 \\
\hline 9 & 10.4 & 5.1 & 17.7 & 10.7 & 3 & 5 & & & 5 \\
\hline 10 & 18.5 & 7.0 & 25 & 11.2 & 7 & 7 & 15 & 24 & 5 \\
\hline 11 & 26.6 & 8.9 & 33 & 12.0 & 7 & 7 & & 23 & 5 \\
\hline 12 & 47.6 & 15.4 & 54 & 17.8 & 5 & 6 & & & 5 \\
\hline 13 & 81.4 & 26.7 & 87 & 28.5 & 0.5 & 0.5 & & & 0.5 \\
\hline
\end{tabular}

\footnotetext{
${ }^{a}$ Determined by linear interpolation of the postirradiation measurements of the graphite sleeve outer diameter; see section on Dimensional Change Data.

${ }^{b}$ Determined from the measured postirradiation diameter of intact rods (see section on Dimensional Change Data) assuming the inner diameter of the graphite sleeve underwent the same fractional shrinkage as its outer diameter.
} 
inverted were much higher than the HTGR maximum design temperature. Rods 1 through 5 operated at "normal" temperatures throughout the test (i.e., less than $50^{\circ} \mathrm{C}$ more than the HTGR maximum design temperature). The average temperature gradients in the rods varied from 280 to $610^{\circ} \mathrm{C} / \mathrm{cm}$ at the beginning of the test and from 220 to $1130^{\circ} \mathrm{C} / \mathrm{cm}$ at the beginning of the last cycle. Rods 1 through 5 had initial average temperature gradients approximately 1.5 times the $1160 \mathrm{MW}(\mathrm{e})$ HTGR maximum design average temperature gradient of $335^{\circ} \mathrm{C} / \mathrm{cm}$ (assuming a maximum heat rate of $7 \mathrm{~kW} / \mathrm{ft}$ in a 0.614 -in.-diam HTGR $\operatorname{rod}^{21}$ with thermal conductivity of $0.07 \mathrm{~W} \mathrm{~cm}^{-1}{ }^{\circ} \mathrm{C}^{-1}$ ).

The calculated temperatures and temperature gradients have large uncertainties because of uncertainties in fission heat rates, gap widths, and thermal conductivity of the bonded rods and loose beds. The uncertainties in the calculated surface and center-line temperatures at the beginning of the test and at the beginning of the irradiation in the inverted position are given in Tables 9 and 10. The temperature uncertainties resulting from reasonable uncertainties in heat rates, gap widths, and thermal conductivity values are combined into a total probable uncertainty and a total maximum uncertainty. The probable temperature uncertainty was defined as the square root of the sum of the squares of the individual uncertainties. The maximum temperature uncertainty was defined as the total uncertainty in temperature if the uncertainty from each effect considered were in the same direction in temperature. In equation form,

$$
\begin{aligned}
& (\overline{\Delta T})=\left[\sum_{i}(\Delta T)_{i}^{2}\right]^{1 / 2}=\text { probable temperature uncertainty, } \\
& (\Delta T)_{\max }=\sum_{i}\left|\Delta T_{i}\right|=\text { maximum temperature uncertainty, }
\end{aligned}
$$

where

$$
\begin{aligned}
\Delta T_{i}= & \text { temperature uncertainty resulting from the uncertainty in parameter } i, \\
i= & \text { fission heat rate, fuel-graphite sleeve gap, graphite-sleeve-stainless-steel gap, or fuel sample } \\
& \text { thermal conductivity. }
\end{aligned}
$$

\begin{tabular}{|c|c|c|c|c|c|c|c|}
\hline \multirow{4}{*}{$\begin{array}{l}\text { Sample } \\
\text { (either } \\
\text { capsule) }\end{array}$} & \multicolumn{7}{|c|}{ Temperature uncertainty $\left({ }^{\circ} \mathrm{C}\right)$} \\
\hline & \multirow{2}{*}{\multicolumn{2}{|c|}{$\begin{array}{c}\text { For fission } \\
\text { rate }=\text { assumed } \\
\text { value } \pm 10 \%\end{array}$}} & \multirow{3}{*}{$\begin{array}{c}\text { In } \Delta T(0) \text { for } \\
\text { fuel conductivity }\end{array}$} & \multicolumn{2}{|c|}{ Probable total } & \multicolumn{2}{|c|}{ Maximum total } \\
\hline & & & & $\overline{\left(\overline{\Delta T_{s}}\right)}$ & $\overline{[\overline{\Delta T(0)}]}$ & $\overline{\left(\Delta T_{S}\right)_{\max }}$ & {$[\Delta T(0)]_{\max }$} \\
\hline & $\Delta T_{S}$ & $\Delta T(0)$ & & & & & \\
\hline 1 & 35 & 60 & 95 & 35 & 110 & 35 & 110 \\
\hline 2 & 40 & 70 & 115 & 40 & 135 & 40 & 185 \\
\hline 3 & 50 & 85 & 125 & 50 & 150 & 50 & 210 \\
\hline 4 & 50 & 85 & 130 & 50 & 155 & 50 & 215 \\
\hline 5 & 50 & 85 & 130 & 50 & 155 & 50 & 215 \\
\hline 6 & 45 & 115 & 260 & 45 & 285 & 45 & 375 \\
\hline 7 & 45 & 75 & 120 & 45 & 140 & 45 & 195 \\
\hline 8 & 35 & 70 & 125 & 35 & 145 & 35 & 195 \\
\hline 9 & 40 & 70 & 115 & 40 & 135 & 40 & 180 \\
\hline 10 & 40 & 65 & 100 & 40 & 120 & 40 & 165 \\
\hline 11 & 40 & 60 & 75 & 40 & 100 & 40 & 135 \\
\hline 12 & 30 & 50 & 60 & 30 & 80 & 30 & 110 \\
\hline 13 & 30 & 50 & 100 & 30 & 110 & 30 & 150 \\
\hline
\end{tabular}

Table 9. Uncertainties in the calculated surface and center-line temperatures at the beginning of cycle 112

\footnotetext{
${ }^{a}$ Based on $0.07_{-25 \%}^{+50 \%} \mathrm{~W} \mathrm{~cm}^{-1}{ }^{\circ} \mathrm{C}^{-1}$ for bonded rods and $0.035_{-25 \%}^{+50 \%} \mathrm{~W} \mathrm{~cm}^{-1}{ }^{\circ} \mathrm{C}^{-1}$ for loose beds.
} 
Table 10. Uncertainties in the calculated surface and center-line temperatures at the beginning of cycle 115

\begin{tabular}{|c|c|c|c|c|c|c|c|c|c|}
\hline \multirow{4}{*}{ Sample } & \multicolumn{9}{|c|}{ Temperature Uncertainty $\left({ }^{\circ} \mathrm{C}\right)$} \\
\hline & \multirow{3}{*}{$\begin{array}{c}\text { For fuel- } \\
\text { graphite gap } \\
=5 \pm 5 \text { mils } \\
{\left[\Delta T_{S}, \Delta T(0)\right]}\end{array}$} & \multirow{3}{*}{$\begin{array}{c}\text { For assumed } \\
\text { graphite-stainless- } \\
\text { steel gap } \pm 2 \text { mils } \\
{\left[\Delta T_{S}, \Delta T(0)\right]}\end{array}$} & \multirow{2}{*}{\multicolumn{2}{|c|}{$\begin{array}{l}\text { For assumed } \\
\text { fission heat } \\
\quad \pm 10 \%\end{array}$}} & \multirow{3}{*}{$\begin{array}{c}\text { For fuel } \\
\text { conductivity }\end{array}$} & \multicolumn{2}{|c|}{ Probable total } & \multicolumn{2}{|c|}{ Maximum total } \\
\hline & & & & & & $\overline{\left(\overline{\Delta T_{s}}\right)}$ & {$[\overline{\Delta T(0)}]$} & $\left(\Delta T_{S}\right)_{\max }$ & {$[\Delta T(0)]_{\max }$} \\
\hline & & & $\Delta T_{S}$ & $\Delta T(0)$ & & & & & \\
\hline H-1-1 & 90 & 40 & 15 & 25 & 35 & 100 & 110 & 145 & 190 \\
\hline $\mathrm{H}-1-2$ & 90 & 40 & 20 & 30 & 45 & 100 & 110 & 150 & 205 \\
\hline H-1-3 & 110 & 40 & 30 & 50 & 65 & 120 & 140 & 180 & 265 \\
\hline H-1-4 & 110 & 40 & 35 & 60 & 75 & 120 & 150 & 185 & 285 \\
\hline $\mathrm{H}-1-5$ & 120 & 35 & 40 & 70 & 90 & 130 & 170 & 195 & 315 \\
\hline H-1-6 & & 40 & 40 & 95 & 220 & 55 & 240 & 80 & 355 \\
\hline H-1-7 & 130 & 35 & 50 & 90 & 115 & 145 & 200 & 215 & 370 \\
\hline $\mathrm{H}-1-8$ & 180 & 55 & 50 & 95 & 125 & 195 & 245 & 285 & 455 \\
\hline $\mathrm{H}-1-9$ & 150 & 50 & 60 & 110 & 135 & 170 & 235 & 260 & 445 \\
\hline H-1-10 & 150 & 40 & 65 & 125 & 165 & 170 & 260 & 255 & 480 \\
\hline$H-1-11$ & 130 & 30 & 70 & 135 & 175 & 150 & 260 & 230 & 470 \\
\hline $\mathrm{H}-1-12$ & 110 & 20 & 75 & 135 & 170 & 135 & 245 & 205 & 435 \\
\hline H-1-13 & & 10 & 65 & 145 & 300 & 65 & 330 & 75 & 455 \\
\hline H-2-1 & 80 & 40 & 15 & 25 & 35 & 90 & 100 & 135 & 180 \\
\hline H-2-2 & 90 & 40 & 20 & 30 & 45 & 100 & 110 & 150 & 205 \\
\hline H-2-3 & 120 & 40 & 25 & 45 & 65 & 130 & 150 & 185 & 270 \\
\hline $\mathrm{H}-2-4$ & 130 & 45 & 35 & 60 & 75 & 140 & 170 & 210 & 310 \\
\hline H-2-5 & 140 & 45 & 45 & 75 & 90 & 150 & 190 & 230 & 350 \\
\hline H-2-6 & & 45 & 40 & 95 & 220 & 60 & 240 & 85 & 360 \\
\hline H-2-7 & 130 & 45 & 55 & 95 & 115 & 150 & 200 & 230 & 385 \\
\hline $\mathrm{H}-2-8$ & 190 & 60 & 55 & 100 & 125 & 210 & 255 & 305 & 475 \\
\hline $\mathrm{H}-2-9$ & 190 & 60 & 50 & 100 & 140 & 205 & 260 & 300 & 490 \\
\hline $\mathrm{H}-2-10$ & 200 & 70 & 60 & 120 & 170 & 220 & 295 & 330 & 560 \\
\hline H-1-11 & 200 & 65 & 65 & 130 & 180 & 220 & 305 & 330 & 575 \\
\hline $\mathrm{H}-2-12$ & 170 & 50 & 70 & 130 & 170 & 190 & 275 & 290 & 520 \\
\hline H-2-13 & & 30 & 60 & 140 & 300 & 70 & 330 & 90 & 470 \\
\hline
\end{tabular}

${ }^{a_{\text {Based on }}} 0.05_{-20 \%}^{+33 \%} \mathrm{~W} \mathrm{~cm}^{-1}{ }^{\circ} \mathrm{C}^{-1}$ for bonded rods and $0.035_{-25 \%}^{+50 \%}$ for loose beds.

The initial temperatures are uncertain primarily because of uncertainties in the fission heat rate and the fuel thermal conductivity. The calculated probable uncertainty in the initial center-line temperatures of the bonded rods varies from 100 to $150^{\circ} \mathrm{C}$. The temperatures calculated at the beginning of the last cycle have the additional large uncertainty in the value of the fuel-graphite gap. The calculated probable uncertainty in the center-line temperatures at the beginning of the last cycle varies from approximately $100^{\circ} \mathrm{C}$ for the low-temperature rods up to approximately $300^{\circ} \mathrm{C}$ for the rods that operated at very high temperatures during the inversion.

The thermal conductivity of bonded rods of coated particles is not well known. The thermal conductivity data of Koyama and $\mathrm{Tye}^{22}$ for unirradiated intrusion-bonded rods fall in the range 0.06 to $0.10 \mathrm{~W} \mathrm{~cm}^{-1}{ }^{\circ} \mathrm{C}^{-1}$ at temperatures between 400 and $1300^{\circ} \mathrm{C}$. The rod thermal conductivity at the beginning of the test was arbitrarily taken to be $0.07 \mathrm{~W} \mathrm{~cm}^{-1}{ }^{\circ} \mathrm{C}^{-1}\left(4 \mathrm{Btu} \mathrm{hr}^{-1} \mathrm{ft}^{-1}{ }^{\circ} \mathrm{F}^{-1}\right)$ for the temperature calculations. To account for the decrease in thermal conductivity because of radiation damage, the rod thermal conductivity during the last irradiation cycle was assumed to be $0.05 \mathrm{~W} \mathrm{~cm}^{-1}{ }^{\circ} \mathrm{C}^{-1}$ ( $3 \mathrm{Btu}$

22. K. Koyama and R. P. Tye, "The Thermal Conductivity of Some Unirradiated HTGR Fuel Element Materials," pp. 153-54 in Eleventh International Thermal Conductivity Conference, Albuquerque, New Mexico, September 28-October 1,1971 , CONF-710938. 
$\mathrm{hr}^{-1} \mathrm{ft}^{-1}{ }^{\circ} \mathrm{F}^{-1}$ ). The conductivity of the loose particle beds was assumed to be $0.035 \mathrm{~W} \mathrm{~cm}^{-1}{ }^{\circ} \mathrm{C}^{-1}$ ( $2 \mathrm{Btu}$ $\mathrm{hr}^{-1} \mathrm{ft}^{-1}{ }^{\circ} \mathrm{F}^{-1}$ ) throughout the test. These conductivity values could easily be in error by $50 \%$ so the calculated center-line temperatures and average temperature gradients can also have large errors, as seen from Eqs. (2) and (3).

The temperatures calculated at the end of cycle 114 and at the beginning and end of cycle 115 have a large uncertainty because of uncertainties in the gap widths. The gaps between the stainless steel and the graphite sleeves at these times were assumed to be approximately the same as the final gaps, which were determined from postirradiation measurements of the graphite sleeve outer diameter (see Table 8). The widths of the fuel-graphite-sleeve gaps at these times are particularly uncertain. The gap widths based on postirradiation diameters measured for some of the rods (see Table 8) are not considered reliable. The measured diameters could be too small because small amounts of material at the rod surfaces could easily have fallen off during removal from the graphite sleeve. Since many of the rods were stuck to the graphite sleeve, there may have been no fuel-graphite gap during the last cycle. As discussed in the section on postirradiation examination, metallography of rod H-1-10 showed that the rod was bonded to the graphite sleeve by a deposit possibly released from the rod while operating at very high temperatures. The fuel-graphite-sleeve gap for rod H-1-10 in the absence of this deposit was apparently at least 13 mils at the end of the last cycle. However, this large gap could have formed after the rod had operated at very high temperatures for some time.

Because of the uncertainty as to whether the fuel-graphite gaps had closed or were larger than the initial gaps, the temperatures during the last cycle were calculated assuming that the gaps were at their initial values (i.e., approximately 5 mils). This assumption is valid if the graphite sleeves and fuel rods shrank at the same rate during the first three irradiation cycles. The radial shrinkage of $\mathrm{H}-327$ is $^{23}$ approximately $1 \%$ when irradiated at about $1200^{\circ} \mathrm{C}$ to $2-4 \times 10^{21}$ neutrons $/ \mathrm{cm}^{2}(>0.18 \mathrm{MeV})$. The shrinkage of intrusion-bonded rods measured in other experiments ${ }^{24}$ is approximately 2 to $4 \%$ for rods containing Biso-coated particles with outer coating densities of $1.85 \mathrm{~g} / \mathrm{cm}^{3}$ irradiated to $2-4 \times 10^{21}$ neutrons $/ \mathrm{cm}^{2}$ $(>0.18 \mathrm{MeV})$. Therefore, on this basis the assumption that the gaps stayed at 5 mils may underestimate the actual gap widths.

The calculated temperatures are also in error because the following effects were neglected: (1) the decrease in thermal conductivity of the graphite sleeve because of irradiation damage (this decrease would result in temperatures approximately 50 to $100^{\circ} \mathrm{C}$ higher than calculated), (2) the axial flow of heat (this flow would result in lower temperatures), (3) the possible asymmetry of the fuel-graphite and graphite-stainless-steel gaps (this asymmetry would result in lower temperatures), and (4) the possible change in the composition of the heat transfer gas from helium to a mixture of helium, carbon monoxide, carbon dioxide, and fission gases (this change would result in higher temperatures).

As discussed earlier, the ${ }^{235} \mathrm{U}$ fission rates assumed in the temperature and burnup calculations were based on the thermal flux measured outside the capsules during each irradiation cycle. This fission rate profile, which is shown in Fig. 4 and in the Appendix, we shall call profile 1. These fission rates are considered to be reliable to within about $10 \%$. However, temperature and burnup were also calculated from other fission rate profiles given in the Appendix: profile 2, based on the unperturbed thermal flux measured during cycle 107B, and profile 3, determined from flux monitor analysis. The initial center-line

23. G. B. Engle and A. L. Pitner, High-Temperature Irradiation Behavior of Production-Grade Nuclear Graphites GA-9973 (July 1970).

24. R. B. Fitts, J. H. Coobs, and R. A. Olstad, "Summary of Fuel Rod Dimensional Changes under Irradiation," ORNL Gas-Cooled Reactor Programs Annu. Progr. Rep. Oct. 1, 1971-Dec. 31, 1972, ORNL-4911, pp. $142-44$. 
temperatures calculated with profile 2 are approximately the same as those calculated using the more reliable profile 1 , but the center-line temperatures after the capsule inversion are 200 to $300^{\circ} \mathrm{C}$ lower for the rods in the top section of the capsule when calculated from profile 2 rather than profile 1 . These lower temperatures do not seem reasonable in light of the extensive damage observed in the rods in the top section of each capsule. The initial center-line temperatures calculated with profile 3 are 200 to $300^{\circ} \mathrm{C}$ higher than those calculated using profile 1 . The temperatures at the beginning of the last cycle using profile 3 appear to be much higher than indicated by the postirradiation condition of the rods. Use of profile 3 results in calculated temperatures as high as $2200^{\circ} \mathrm{C}$ at the surface and $3100^{\circ} \mathrm{C}$ at the center of rods in the top section of the $\mathrm{H}-1$ capsule. These high surface temperatures seem unreasonable considering that the rods were still intact and particles near the surface still had intact coatings. Therefore on the basis of temperature calculations, profile 1 seems to be more reliable than profile 2 and much more reliable than profile 3.

\section{Summary of Irradiation Conditions}

The irradiation conditions in the H-1 and H-2 test are summarized in Table 11 and compared with the irradiation conditions expected in a 1160-MW(e) HTGR. It is impossible to have irradiation conditions in an accelerated test equivalent to an actual full-time irradiation in a power reactor. The H-1 and $\mathrm{H}-2$ test was designed so that the maximum fast neutron fluence in any of the rods was approximately equal to the HTGR design fast fluence. In order to have temperatures and temperature gradients in the $\mathrm{H}-1$ and $\mathrm{H}-2$ test comparable to the HTGR design maximum conditions, the thermal flux was attenuated with the hafnium shrouds, thereby decreasing the fission rate but also decreasing the total burnup of heavy metal that could

Table 11. Comparison of $\mathrm{H}-1$ and $\mathrm{H}-2$ irradiation conditions with those in a 1160-MW(e) HTGR

\begin{tabular}{|c|c|c|}
\hline Irradiation condition & $\mathrm{H}-1$ and $\mathrm{H}-2$ & HTGR \\
\hline $\begin{array}{r}\text { Maximum fast fluence }(>0.18 \mathrm{MeV}) \\
\text { neutrons } / \mathrm{cm}^{2}\end{array}$ & $6 \times 10^{21}$ & $8 \times 10^{21}$ \\
\hline $\begin{array}{r}\text { Maximum fast flux }(>0.18 \mathrm{MeV}), \\
\text { neutrons } \mathrm{cm}^{-2} \mathrm{sec}^{-1}\end{array}$ & $6 \times 10^{14}$ & $8 \times 10^{13}$ \\
\hline Th burnup, \% FIMA & $<0.5$ & 7 \\
\hline U burnup, \% FIMA & $26-44$ & 75 \\
\hline $\begin{array}{l}(4.1 \mathrm{Th}, \mathrm{U}) \mathrm{O}_{2} \text { burnup, \% FIMA } \\
\text { Linear heat rate } \mathrm{kW} / \mathrm{ft}\end{array}$ & $7-9$ & 20 \\
\hline $\begin{array}{l}\text { Maximum values for } 0.5 \text {-in.-diam } \\
\text { rods in } \mathrm{H}-1 \text { and } \mathrm{H}-2 \text { capsules }\end{array}$ & $7-14$ & \\
\hline \multicolumn{3}{|l|}{$\begin{array}{l}\text { Values for } 0.614 \text {-in.-diam rods } \\
\text { in an HTGR: }\end{array}$} \\
\hline Maximum & & 7 \\
\hline Average & & 2.5 \\
\hline $\begin{array}{l}\text { Maximum center-line temperature, }{ }^{\circ} \mathrm{C} \\
\text { Temperature gradient at } 1 / 2 \text { rod radius, }{ }^{\circ} \mathrm{C} / \mathrm{cm}\end{array}$ & $1030-2600$ & 1420 \\
\hline Maximum values in $\mathrm{H}-1$ and $\mathrm{H}-2$ & $470-1130$ & \\
\hline HTGR maximum & & 335 \\
\hline HTGR average & & 120 \\
\hline Irradiation time, years & 0.5 & 4 \\
\hline
\end{tabular}

${ }^{a}$ From Delmarva Power and Light Company, Preliminary Safety Analysis Report for the Summit Power Station, Docket Nos. 50-450 and 50-451 (1973), Table 4.4.2-3. 
be obtained. However, because the capsules were inverted during the last cycle, the temperatures and temperature gradients in some of the rods were much greater than for a 1160-MW(e) HTGR. If the hafnium shrouds had not been used, high burnup values as well as the desired temperatures and temperature gradients could have been obtained if a smaller ratio of fissile to fertile particles had been used. This method would also have had the disadvantage that the fission rate in the fissile particles would have been much larger than in an HTGR. If the fission rate in a fissile particle is too large, its temperature can be significantly higher than that of neighboring fertile particles, so temperatures calculated assuming that the fission heat source is uniformly distributed in a rod lead to erroneous results.

\section{POSTIRRADIATION EXAMINATION OF FUEL SAMPLES}

\section{Visual Examination}

When the capsules were opened after the irradiation, none of the fuel samples could be pushed out of the graphite sleeves. The sleeves were split open to remove the fuel samples. All the rods were stuck to the graphite sleeve and could not be removed easily. The visual observations that were made before and during the removal of the samples are given in Table 12. The appearance of several rods that operated at normal temperatures throughout the test is shown in Fig. 6, and some that operated at very high temperatures during the last cycle are shown in Fig. 7. For comparison, Fig. 8 shows that, with the exception of some end-cap cracks, the preirradiation appearance of the rods was good.

Several of the rods that operated at normal temperatures $\left(<1450^{\circ} \mathrm{C}\right)$ throughout the test were either fragmented or debonded. This behavior was not expected and was not consistent with the good performance observed ${ }^{25}$ for the same matrix material in the HRB-2 irradiation test. These rods may have fragmented or debonded because of the relatively high initial temperature gradients - approximately $50 \%$ greater than the maximum gradient in a 1160-MW(e) HTGR. Another possible cause of the fragmentation and debonding may have been the thermal stresses induced by repeated thermal cycling during the irradiation. In addition to the approximately 35 times the ETR was brought from zero to greater than $90 \%$ full power during the test, the reactor was brought from 0 to $40 \%$ full power about 70 times in a period of several days when ETR personnel were conducting tests to determine the source of the reactor power oscillations.

The primary feature of some of the rods that operated at very high temperatures $\left(>1750^{\circ} \mathrm{C}\right)$ was the formation of a central core containing reddish powder rather than discrete particles. No chemical analysis was performed to determine the composition of this powder, but it is thought to have been an oxide of uranium that was formed by the reaction of uranium carbide with the humid cell atmosphere. Some of the high-temperature rods had a rough surface, which showed exposed fuel kernels, as in Fig. $7 b$. Some of the "caps" of the particles may have stuck to the graphite sleeve during removal, but metallographic examination of rods $\mathrm{H}-1-10, \mathrm{H}-1-12, \mathrm{H}-2-10$, and $\mathrm{H}-2-11$ showed that the particle coatings at the rod surface had apparently been attacked by fission products or other oxidizing chemical species released from the center of the damaged fuel rods.

25. J. H. Coobs, J. L. Scott, B. H. Montgomery, J M Robbins, C. B. Pollock, and J. A. Conlin, Irradiation Performance in HFIR Experiment HRB-2 of HTGR Fuel Stocks Bonded with Reference and Advanced Matrix Materials, ORNL-TM-3988 (Jan. 1973). 
Table 12. Visual observations of the irradiated H-1 and $\mathbf{H}-2$ fuel samples

\begin{tabular}{|c|c|c|c|c|}
\hline \multirow[t]{2}{*}{ Sample } & \multirow[t]{2}{*}{$\begin{array}{l}\text { Particle } \\
\text { combination }\end{array}$} & \multicolumn{2}{|c|}{$\begin{array}{l}\text { Calculated maximum } \\
\text { temperature during } \\
\text { test }\left({ }^{\circ} \mathrm{C}\right)\end{array}$} & \multirow[t]{2}{*}{ Visual observations } \\
\hline & & Surface & Center line & \\
\hline H-1-1 & f & 770 & 1070 & $\begin{array}{l}\text { Rod intact except for some end chipping during removal } \\
\text { Surface looked very smooth }\end{array}$ \\
\hline$H-1-2$ & $\mathbf{g}$ & 890 & 1250 & $\begin{array}{l}\text { Rod fragmented and largely debonded in center. Ends essentially } \\
\text { intact until broken during removal }\end{array}$ \\
\hline $\mathrm{H}-1-3$ & c & 980 & 1370 & $\begin{array}{l}\text { Large fragments on opening. Completely debonded durıng removal. } \\
\text { No faled particles visible }\end{array}$ \\
\hline H-1-4 & a & 1030 & 1420 & $\begin{array}{l}\text { Rod intact. Some surface spalling Fragmented into two sections } \\
\text { during removal. }\end{array}$ \\
\hline $\mathrm{H}-1-5$ & f & 1070 & 1460 & $\begin{array}{l}\text { Rod severely debonded and appeared to deteriorate more on } \\
\text { exposure to the cell atmosphere. Some shiny kernels or S1C } \\
\text { coatıngs visible. }\end{array}$ \\
\hline $\mathrm{H}-1-6^{a}$ & a & 1000 & 1670 & Some cracked coatings and several bare kernels visible. \\
\hline $\mathrm{H}-1-7$ & $\mathbf{R}$ & 1230 & 1690 & $\begin{array}{l}\text { Rod intact on opening but fragmented during removal } \\
\text { Few cracked coatıngs }\end{array}$ \\
\hline $\mathrm{H}-1-8$ & $\mathbf{R}$ & 970 & 1460 & $\begin{array}{l}\text { Completely debonded to loose particles Interior of sleeve } \\
\text { had a sootlıke deposit Large number of coatıng fragments and } \\
\text { kernels }\end{array}$ \\
\hline$H-1-9$ & f & 1180 & 1720 & $\begin{array}{l}\text { Rod largely debonded or fragmented Many loose kernels or } \mathrm{S}_{1} \mathrm{C} \\
\text { coatings. }\end{array}$ \\
\hline $\mathrm{H}-1-10$ & a & 1480 & 2150 & $\begin{array}{l}\text { Rod intact with one transverse crack. Some fragmentation on } \\
\text { sitting Reddish powder in center of rod. Damaged particles } \\
\text { on rod surface }\end{array}$ \\
\hline$H-1-11$ & c & 1680 & 2390 & $\begin{array}{l}\text { Rod broken into large fragments on opening and deteriorated } \\
\text { severely in cell atmosphere. Damaged particles at rod surface }\end{array}$ \\
\hline $\mathrm{H}-1-12$ & g & 1880 & 2570 & $\begin{array}{l}\text { Rod intact with end near top broken off when holder broke. } \\
\text { Reddish powder in central core. }\end{array}$ \\
\hline $\mathrm{H}-1-13^{a}$ & $\mathbf{g}$ & 1880 & 2790 & Loose particles bonded together Some cracked particles visible \\
\hline $\mathrm{H}-2-1$ & f & 720 & 1030 & Rod broken into two large sections Very few loose particles \\
\hline $\mathrm{H}-2-2$ & g & 830 & 1200 & Rod broken into three sections. Some loose particles. \\
\hline $\mathrm{H}-2-3$ & c & 970 & 1350 & Rod broken into four large sections Very few loose particles \\
\hline $\mathrm{H}-2-4$ & a & 1040 & 1430 & Rod intact Some minor surface sloughing. \\
\hline $\mathrm{H}-2-5$ & f & 1010 & 1400 & Rod debonded. Bare kernels of $\mathrm{SiC}$ coatings visible. \\
\hline$H-2-6^{a}$ & $\mathrm{a}$ & 940 & 1690 & Few broken coatings visible. \\
\hline H-2-7 & $\mathbf{R}$ & 1130 & 1600 & Rod completely debonded. Some bare kernels visible \\
\hline H-2-8 & $\mathbf{R}$ & 910 & 1410 & $\begin{array}{l}\text { Rod intact with longitudınal crack. Broke along crack during } \\
\text { removal. Some failed particles visıle. }\end{array}$ \\
\hline $\mathrm{H}-2-9$ & f & 1000 & 1560 & $\begin{array}{l}\text { Rod intact when sleeve opened. Disintegrated to powder in } \\
\text { cell atmosphere within } 16 \mathrm{hr} \text {. Many kernels and } \\
\text { coatıng fragments visible. }\end{array}$ \\
\hline H-2-10 & a & 1120 & 1800 & $\begin{array}{l}\text { Rod intact with some transverse crackıng. Some fragmentation } \\
\text { on removal. Had small-diameter central core of reddısh powder } \\
\text { Many damaged surface particles. }\end{array}$ \\
\hline H-2-11 & $\mathrm{c}$ & 1190 & 1910 & $\begin{array}{l}\text { Rod intact. Some cracking of end toward capsule center Broke } \\
\text { during removal. Had small-diameter central core of reddish powder }\end{array}$ \\
\hline H-2-12 & $\mathbf{g}$ & 1350 & 2050 & $\begin{array}{l}\text { Rod fragmented into large pieces and some loose particles. Few } \\
\text { broken particles apparent }\end{array}$ \\
\hline H-2-13 ${ }^{a}$ & $\mathrm{~g}$ & 1340 & 2260 & $\begin{array}{l}\text { Loose bed of particles sintered together. Some fallures observed. } \\
\text { Most of bed was still loose particles. }\end{array}$ \\
\hline
\end{tabular}

${ }^{a}$ Loose particle beds. 

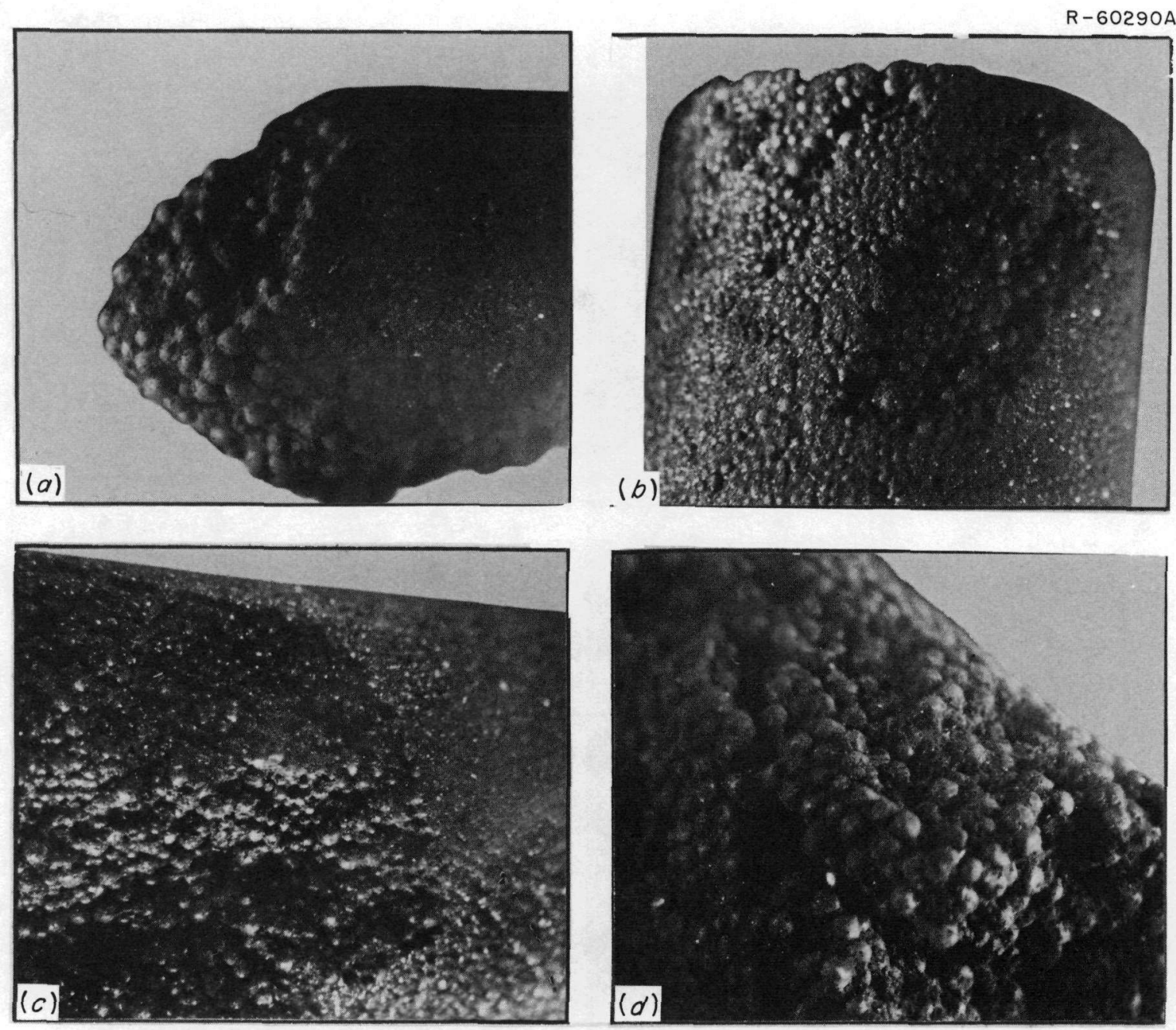

Fig. 6. Macroscopic appearance of bonded rods that operated at normal temperatures throughout the test. $6.5 \times$. (a) Rod H-2-3. (b) Rod H-2-2. (c) Rod H-1-1. (d) Rod H-2-4. Reduced 18\%.
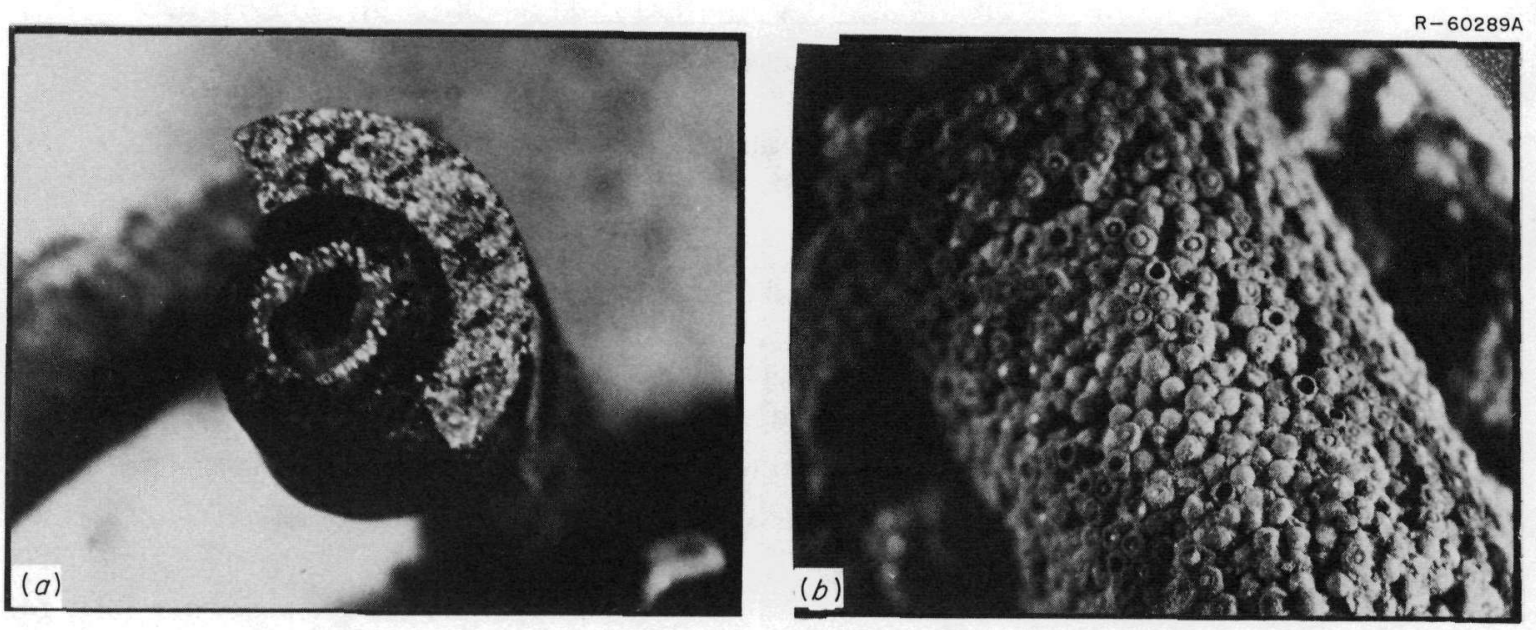

Fig. 7. Macroscopic appearance of bonded rods that operated at very high temperatures during the last irradiation cycle. (a) Rod H-1-10, showing central core and bond with the graphite sleeve. $3 \times$. (b) Rod H-2-10, showing exposed fuel kernels at rod surface. $6 \times$. Reduced $38 \%$. 
PHOTO $0502-71 \mathrm{~A}$

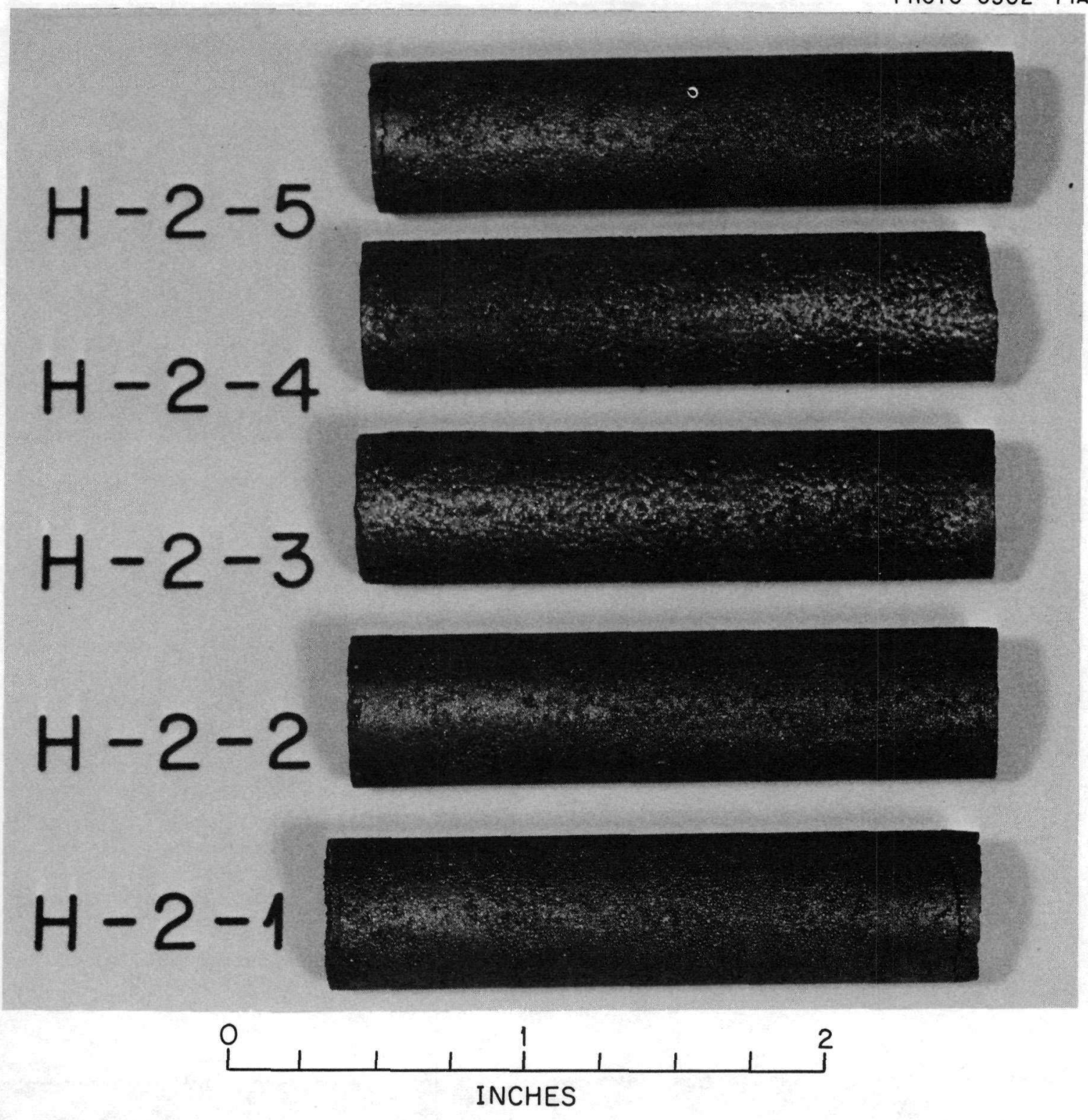

Fig. 8. Typical appearance of unirradiated rods.

\section{Dimensional Change Data}

The postirradiation diameters of the H-327 graphite sleeves were measured at several axial positions on each sleeve. These data, given in Table 13, were used to determine the end-of-life gaps between the graphite sleeves and the stainless steel capsules. In addition to the shrinkage, the sleeves had a maximum bow of from 0.023 to 0.048 in., which caused the gap between the graphite sleeve and the stainless steel to be asymmetric at some fuel positions.

The postirradiation diameters were measured on those rods that were still intact. As shown in Table 14, the rods apparently shrank from 2 to $8 \%$ as determined from the initial and final measured diameters. This 
is somewhat greater than the 2 to $5 \%$ shrinkage observed ${ }^{26}$ in other irradiation tests for comparable fast neutron fluences and particle coating densities. The data in Table 14 are not considered to be reliable because some particles at the surface had either debonded or lost part of their coatings.

\section{Metallography of Fuel Rods That Operated at Normal Temperatures throughout the Test}

Metallography of irradiated rods is useful for detecting the presence of broken coatings, matrix-particle interactions, and the extent of kernel migration (the so-called amoeba effect) up a temperature gradient because of the transport of carbon from the hot side to the cold side of a particle. The amoeba effect has been observed when coated particles are kept at high temperatures in a temperature gradient both in and

26. R. B. Fitts, J. H. Coobs, and R. A. Olstad, "Summary of Fuel Rod Dimensional Changes under Irradiation," ORNL Gas-Cooled Reactor Programs Annu. Progr. Rep. Oct. 1, 1971-Dec. 31, 1972, ORNL-4911, pp. $142-44$.

Table 13. Graphite sleeve dimensional change data

\begin{tabular}{lccc}
\hline \multirow{2}{*}{$\begin{array}{c}\text { Location of } \\
\text { measurement }\end{array}$} & $\begin{array}{c}\text { Diameter (in.) } \\
\end{array}$ & $\begin{array}{c}\text { Preirradiation, } \\
D_{0}\end{array}$ & $\begin{array}{c}\text { Postirradiation, } \\
D\end{array}$ \\
\hline Below H-1-1 & 0.8639 & 0.8515 & \\
Above H-1-7 & 0.8437 & 0.8285 & -1.44 \\
Below H-1-8 & 0.8688 & 0.8535 & -1.80 \\
Above H-1-11 & 0.8145 & 0.8028 & -1.76 \\
Above H-1-13 & 0.6826 & $\sim 0.669$ & -1.44 \\
Below H-2-1 & 0.8699 & 0.8559 & -1.99 \\
Above H-2-7 & 0.8422 & 0.8371 & -1.61 \\
Below H-2-8 & 0.8688 & 0.8561 & -0.61 \\
Above H-2-11 & 0.8565 & 0.8515 & -1.46 \\
Above H-2-13 & 0.8126 & 0.8095 & -0.58 \\
\hline
\end{tabular}

Table 14. Fuel rod dimensional change data

\begin{tabular}{lcccc}
\hline & & \multicolumn{2}{c}{ Diameter (in.) } & \\
\cline { 3 - 5 } Rod & $\begin{array}{c}\text { Particle } \\
\text { combination }\end{array}$ & $\begin{array}{c}\text { Preirradiation, } \\
D_{0}\end{array}$ & $\begin{array}{c}\text { Postirradiation, } \\
{ }^{a}\end{array}$ & $\left(D-D_{0}\right) / D_{0}(\%)$ \\
\hline H-1-1 & f & 0.4930 & 0.4750 & \\
H-1-4 & a & 0.4889 & 0.4793 & -3.7 \\
H-1-10 & a & 0.4869 & 0.4625 & -2.0 \\
H-2-1 & f & 0.4936 & 0.4769 & -3.0 \\
H-2-2 & g & 0.4899 & 0.4764 & -2.8 \\
H-2-3 & c & 0.4875 & 0.4731 & -3.0 \\
H-2-4 & a & 0.4871 & 0.4695 & -3.6 \\
H-2-10 & a & 0.4866 & 0.4485 & -7.8 \\
H-2-11 & c & 0.4871 & 0.4518 & -7.2 \\
\hline
\end{tabular}

${ }^{a}$ Maximum diameter measured on any portion of the rod still intact after removal from the graphite sleeve. 
out of reactor. 27-32 Although metallography can detect broken coatings, the statistics of particle failure fraction determined by this method are very poor because of the small fraction of the particles in a rod that appear on a single polished plane of that rod.

The rods that operated at normal temperatures throughout the test and were examined metallographically are H-1-2, H-1-3, and H-1-4. Radial cross sections of rod H-1-2, which contained Biso-coated $\mathrm{UO}_{2}$ and $\mathrm{ThO}_{2}$ kernels, are shown in Figs. 9 and 10. In the portion of the rod that was examined, there is no apparent matrix cracking. No broken coatings are observed, and there is no apparent adverse matrix-coating interaction. The $\mathrm{ThO}_{2}$ particles show very little effect from the irradiation, as shown in the pre- and postirradiation photomicrographs in Fig. 11. No $\mathrm{ThO}_{2}$ kernel migration is evident. The $\mathrm{UO}_{2}$ kernels in the rod exhibited a small amount of amoeba effect, as shown in Fig. 12 for a typical $\mathrm{UO}_{2}$ particle near the rod surface. This $\mathrm{UO}_{2}$ kernel migrated through the recoil zone of dense carbon surrounding the initial kernel position but was still well contained by the buffer. Close examination of the kernel reveals that a dense carbon surrounds the migrating kernel and infiltrates into the regions between the $\mathrm{UO}_{2}$ grains at the edge of the kernel.

The $\mathrm{UO}_{2}$ particle shown in Fig. 12 has also been examined with an electron microprobe to determine the location of various fission products in the vicinity of the kernel. As shown in Fig. 13, the white inclusions evident in the photomicrograph of the kernel contain molybdenum, ruthenium, and possibly barium, but not uranium. The cesium largely surrounds the kernel and diffuses into the buffer. A particularly interesting but unexplained observation is that the barium is located primarily at the leading edge of the migrating kernel. This indicates that the transport of fission products may be involved in the mechanism for kernel migration.

The $\mathrm{ThO}_{2}$ particles in rod H-1-3 were relatively unaffected by the irradiation and appear the same as those in rod H-1-2. A very small amount of migration was observed in some of the $(2.2 \mathrm{Th}, \mathrm{U}) \mathrm{O}_{2}$ kernels, as shown in Fig. 14a. Even though rod H-1-3 completely debonded during removal from the capsule, no broken coatings were observed. However, some of the outer pyrolytic carbon coatings of the $(2.2 \mathrm{Th}, \mathrm{U}) \mathrm{O}_{2}$ particles had small cracks at the outer surface, as shown in Fig. 14b. These cracks were probably caused by the stresses induced in the relatively low-density $\left(1.85 \mathrm{~g} / \mathrm{cm}^{3}\right)$ outer coatings as they densified. Preirradiation micrographs of the $(2.2 \mathrm{Th}, \mathrm{U}) \mathrm{O}_{2}$ particles (Fig. 15) show that the outer coatings were initially isotropic but had highly oriented porosity. The unirradiated $(4.1 \mathrm{Th}, \mathrm{U}) \mathrm{O}_{2}$ particles (Fig. 16) had less oriented porosity in the outer coatings than did the $(2.2 \mathrm{Th}, \mathrm{U}) \mathrm{O}_{2}$ particles.

A radial section of rod H-1-4 is shown in Fig. 17. Many of the $(4.1 \mathrm{Th}, \mathrm{U}) \mathrm{O}_{2}$ particles in this rod were nonspherical because portions of the kernels had cracked off before coating. Some coating failures were observed for $(4.1 \mathrm{Th}, \mathrm{U}) \mathrm{O}_{2}$ particles with very thin pyrolytic carbon coatings and no buffer coating, as shown in Fig. 18a. However, no failures were observed for particles with the proper coating configuration. A small amount of kernel migration was observed in the $(4.1 \mathrm{Th}, \mathrm{U}) \mathrm{O}_{2}$ kernels, as shown in Fig. $18 b$. No $\mathrm{ThO}_{2}$ migration was observed in any of the particles in this rod.

27. J. L. Scott et al., An Irradiation Test of Bonded HTGR Coated Particle Fuels in an Instrumented Capsule in HFIR, ORNL-TM-3640 (March 1972).

28. T. D. Gulden, "Carbon Thermal Diffusion in the $\mathrm{UC}_{2}$-C System," J. Amer. Ceram. Soc. $55: 14$ (1972).

29. C. B. Scott and O. M. Stansfield, Stability of Irradiated Coated-Particle Fuels in a Temperature Gradient, Gulf-GA-A12081 (1972).

30. O. M. Stansfield, C. B. Scott, and T. D. Gulden, Fuel Kernel Migration in Carbide Coated Particle Fuels, Gulf-GA-10225 (to be issued).

31. T. B. Lindemer and H. J. de Nordwall, An Analysis of Chemical Failure of Oxide Fuel Particles in the High-Temperature Gas-Cooled Reactor, ORNL-4926 (January 1974).

32. T. B. Lindemer and R. A. Olstad, HTGR Fuel Kernel Migration Data for the Th-U-C-O System as of April 1 , 1974, ORNL-TM-4493 (in preparation). 


\section{-}

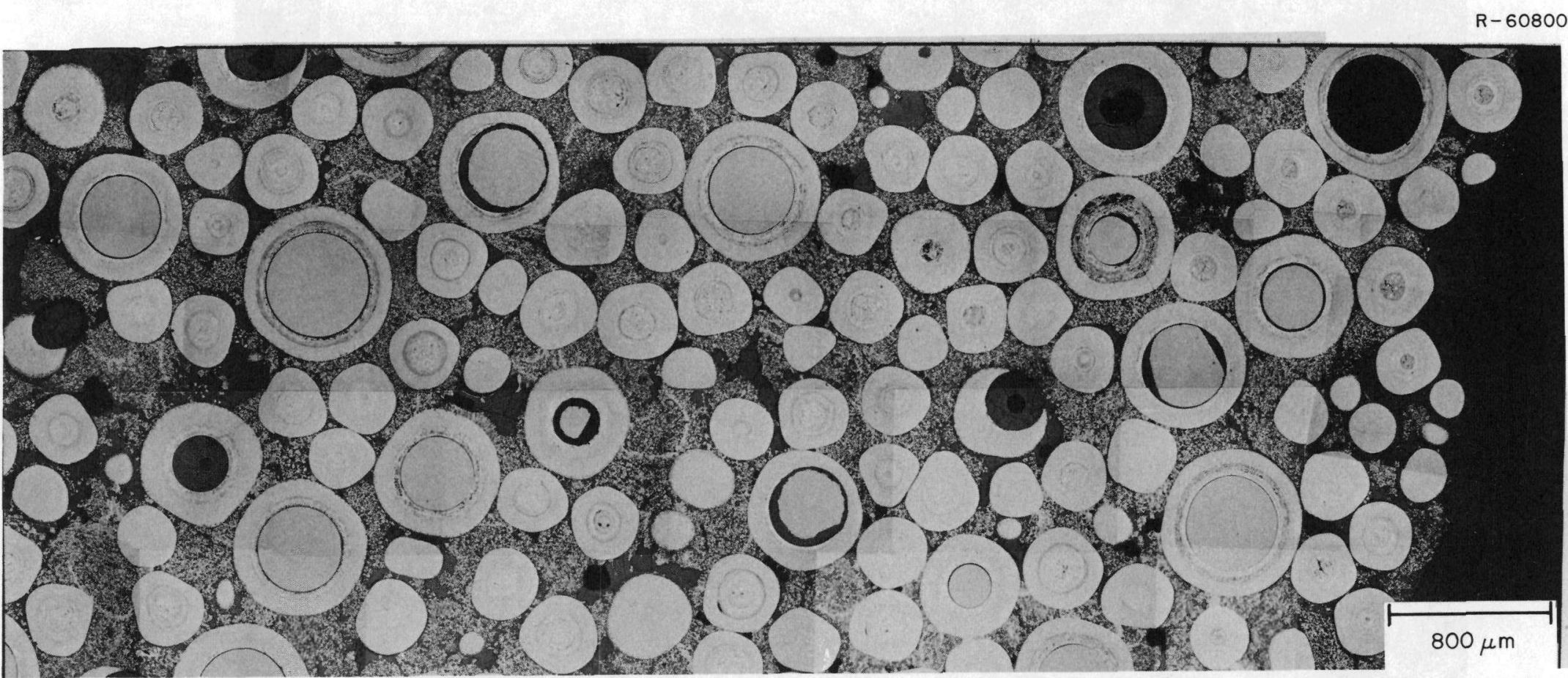

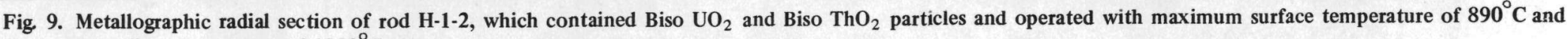
maximum center-line temperature of $1250^{\circ} \mathrm{C}$. 
PHOTO $Y-120441$

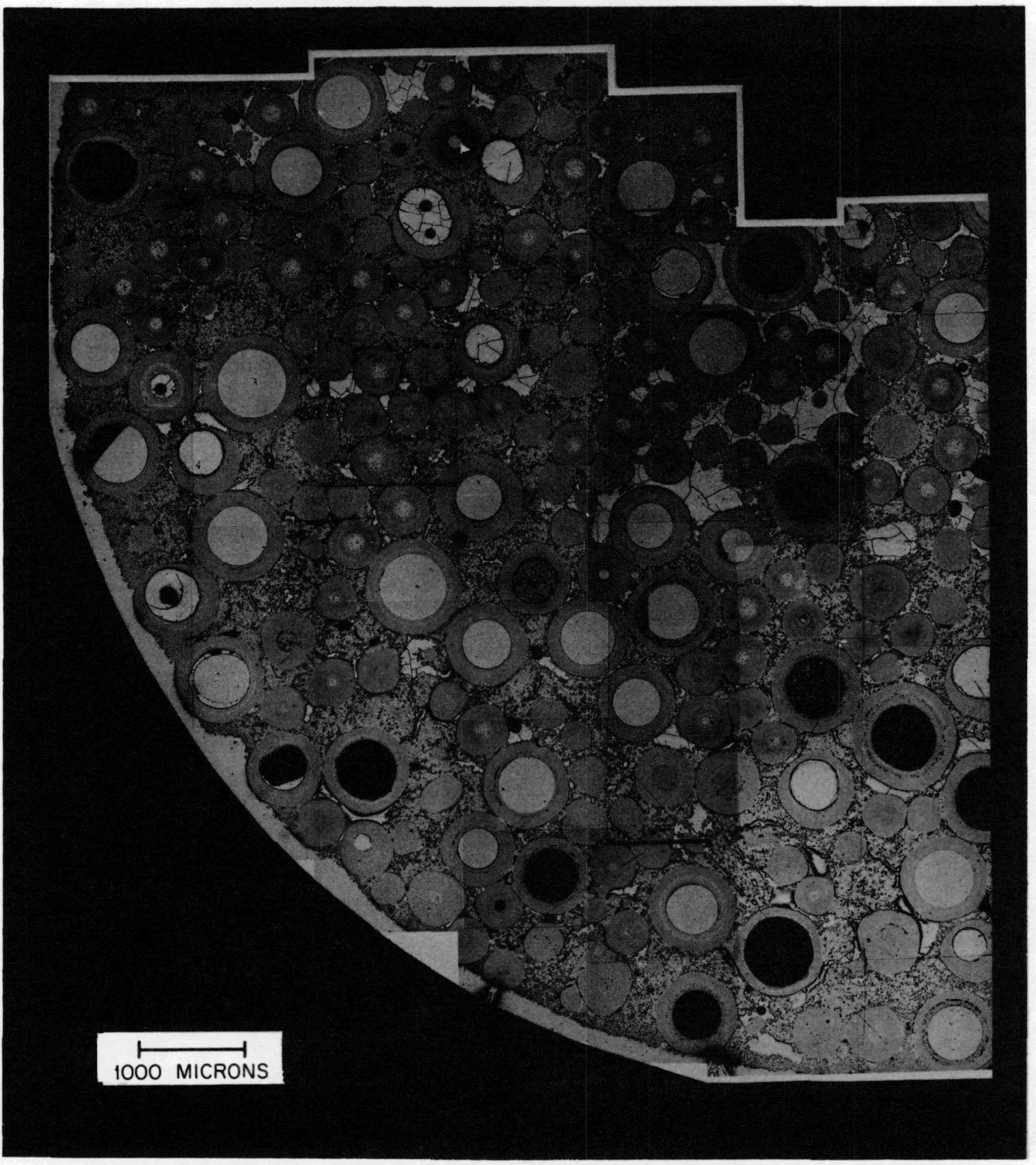

Fig. 10. Low-magnification radial section of rod H-1-2, used in measuring kernel migration. Bright field. Scale indicates $500 \mu \mathrm{m}$. 

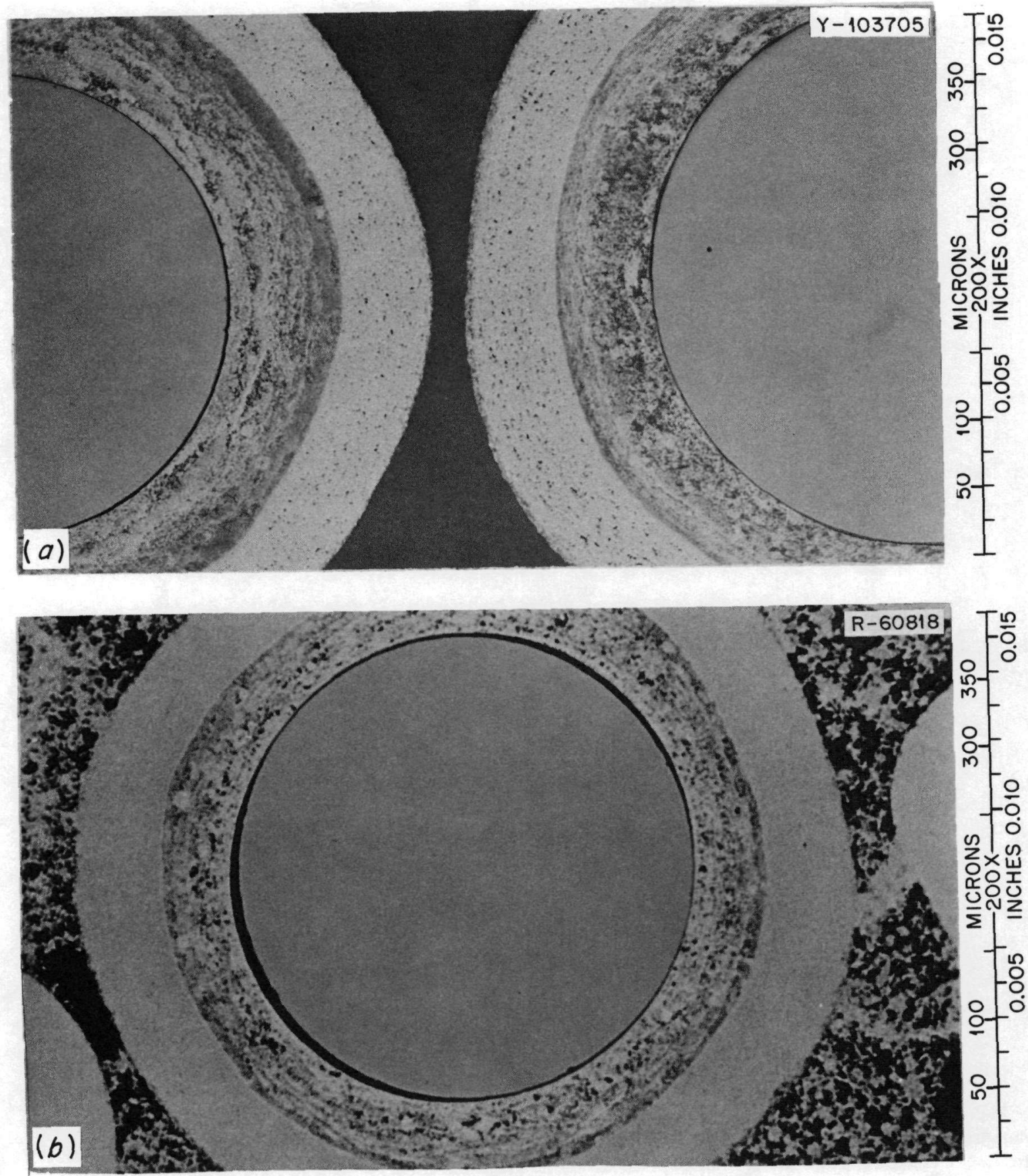

Fig. 11. Biso $\mathrm{ThO}_{2}$ particles. (a) Unirradiated. (b) Irradiated in rod $\mathrm{H}-1-2$. 


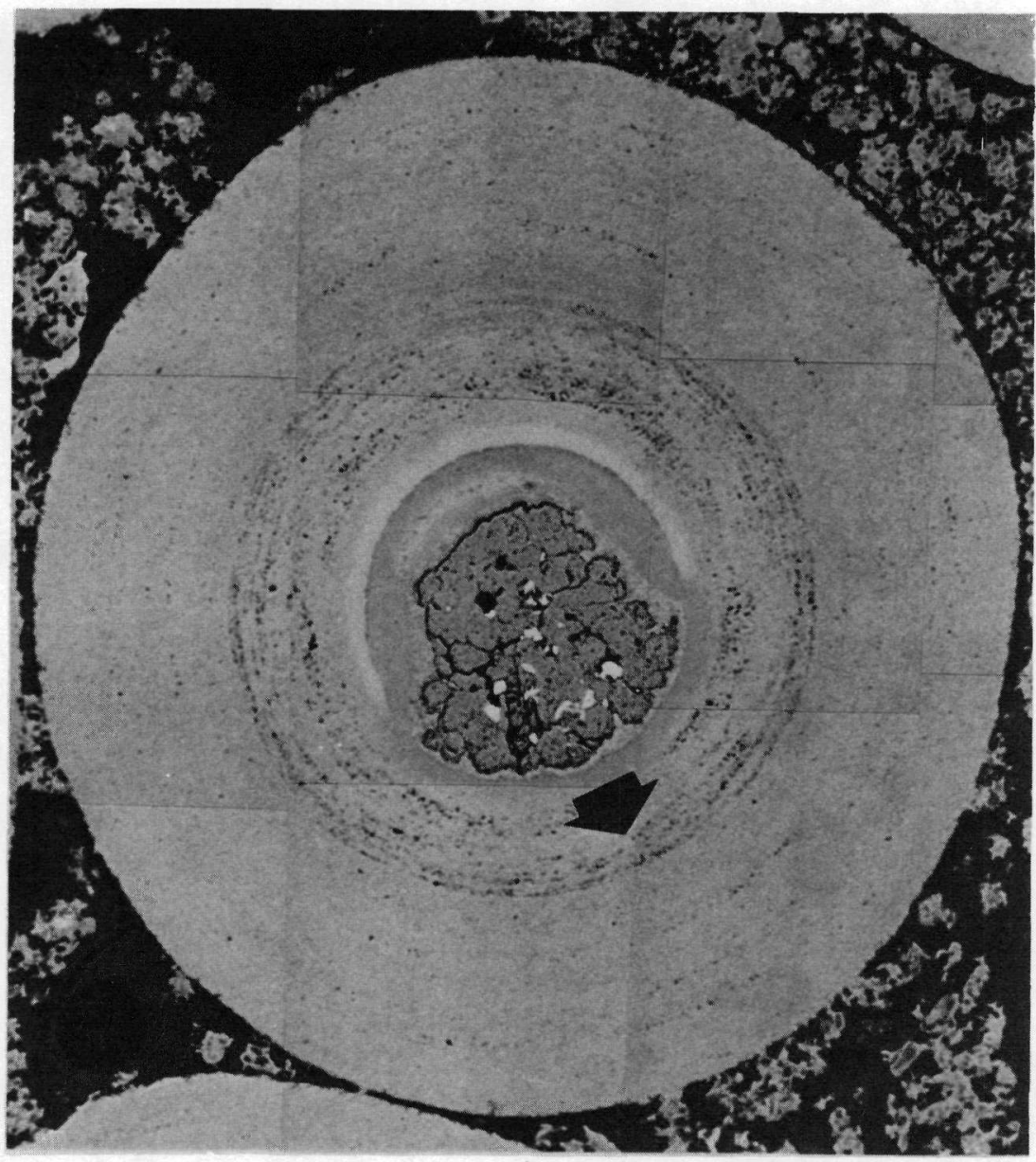

Fig. 12. Biso $\mathrm{UO}_{2}$ particle irradiated at edge of rod $\mathrm{H}-1-2$ at a maximum temperature of $950^{\circ} \mathrm{C}$ in a maximum temperature gradient of approximately $1000^{\circ} \mathrm{C} / \mathrm{cm}$. The arrow points to the center of the rod and is therefore in the direction of increasing temperature. Note the small amount of kernel migration up the temperature gradient. 300X. 


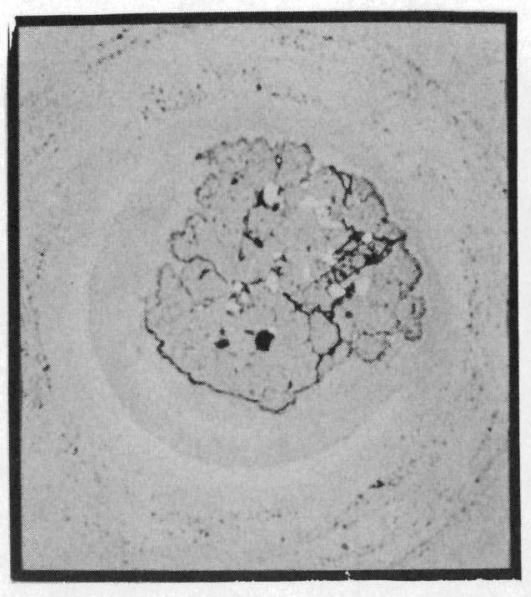

PHOTOMICROGRAP

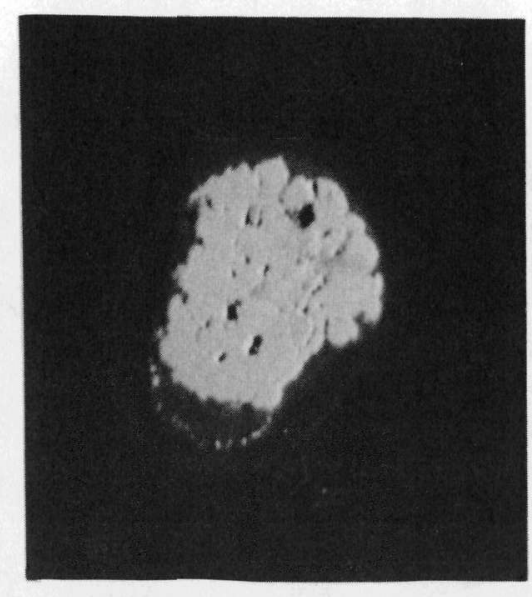

BACKSCATTERED ELECTRONS

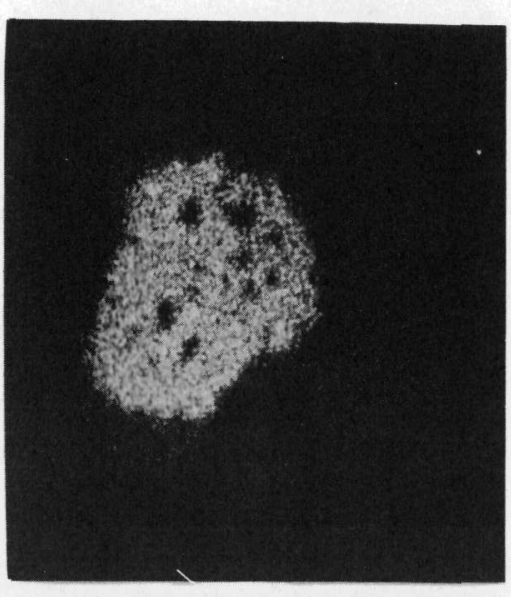

$U M_{\beta}$

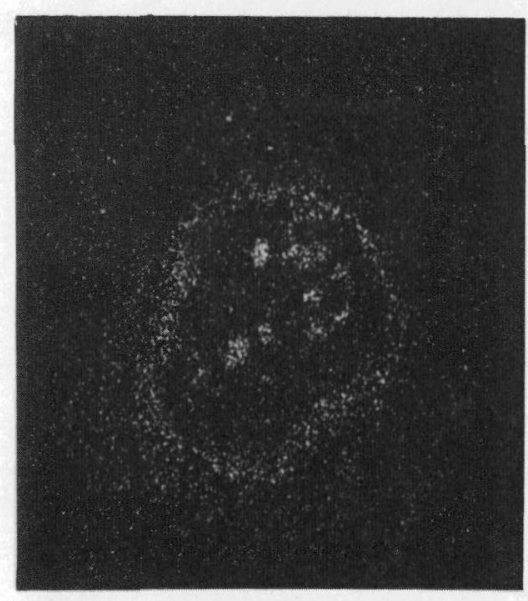

Mo La

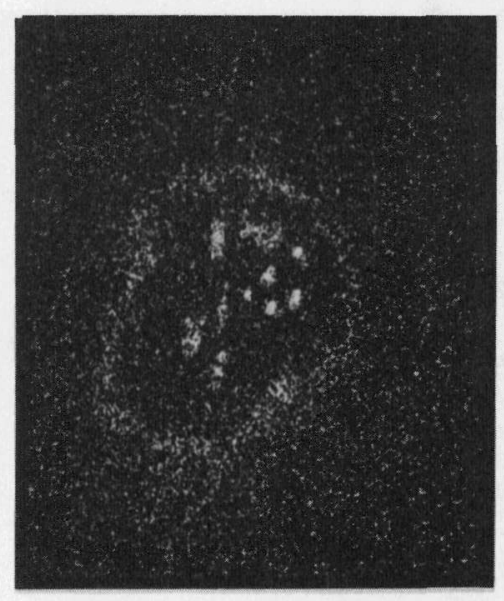

Ru La

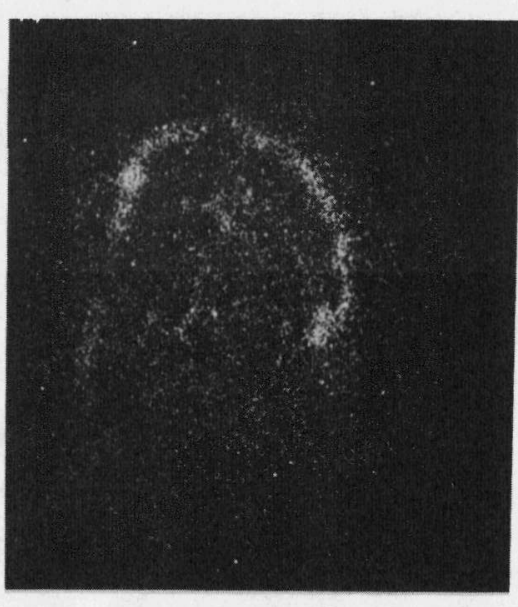

$B a L_{\alpha}$

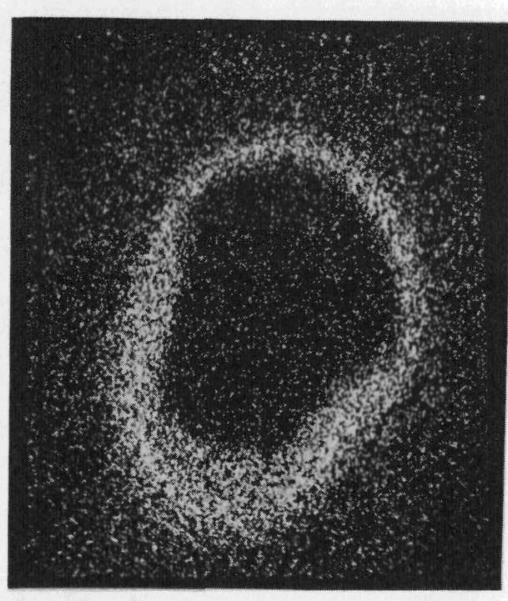

Cs $L_{\alpha}$

Fig. 13. Electron microprobe analyses of a Biso-coated $\mathrm{UO}_{2}$ kernel irradiated in rod H-1-2. 

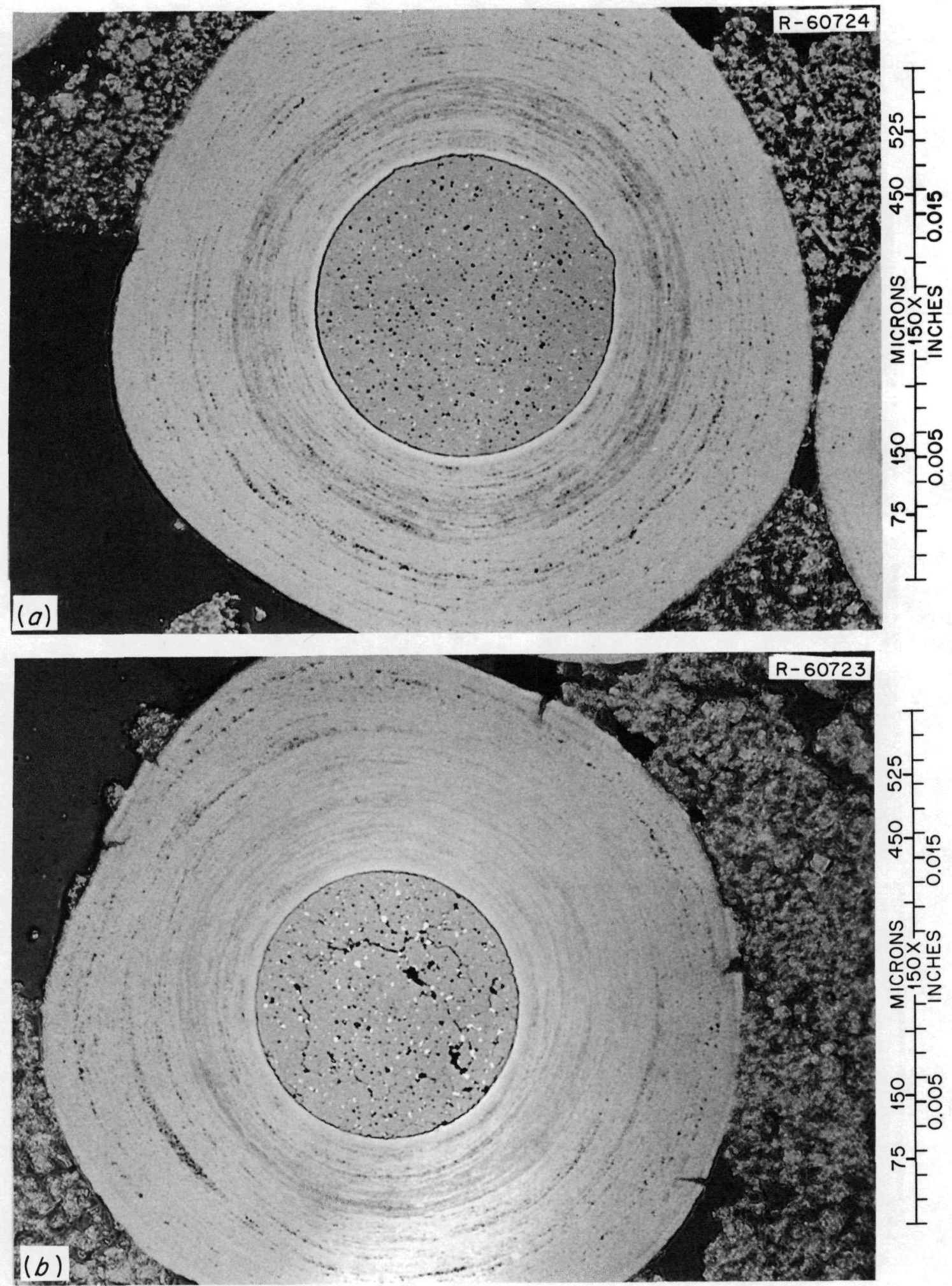

Fig. 14. Biso-coated (2.2Th, $\mathbf{U}) \mathrm{O}_{2}$ particles irradiated in rod H-1-3. (a) Kernel showing very small amount of migration. (b) Outer coating with small cracks at the surface. 

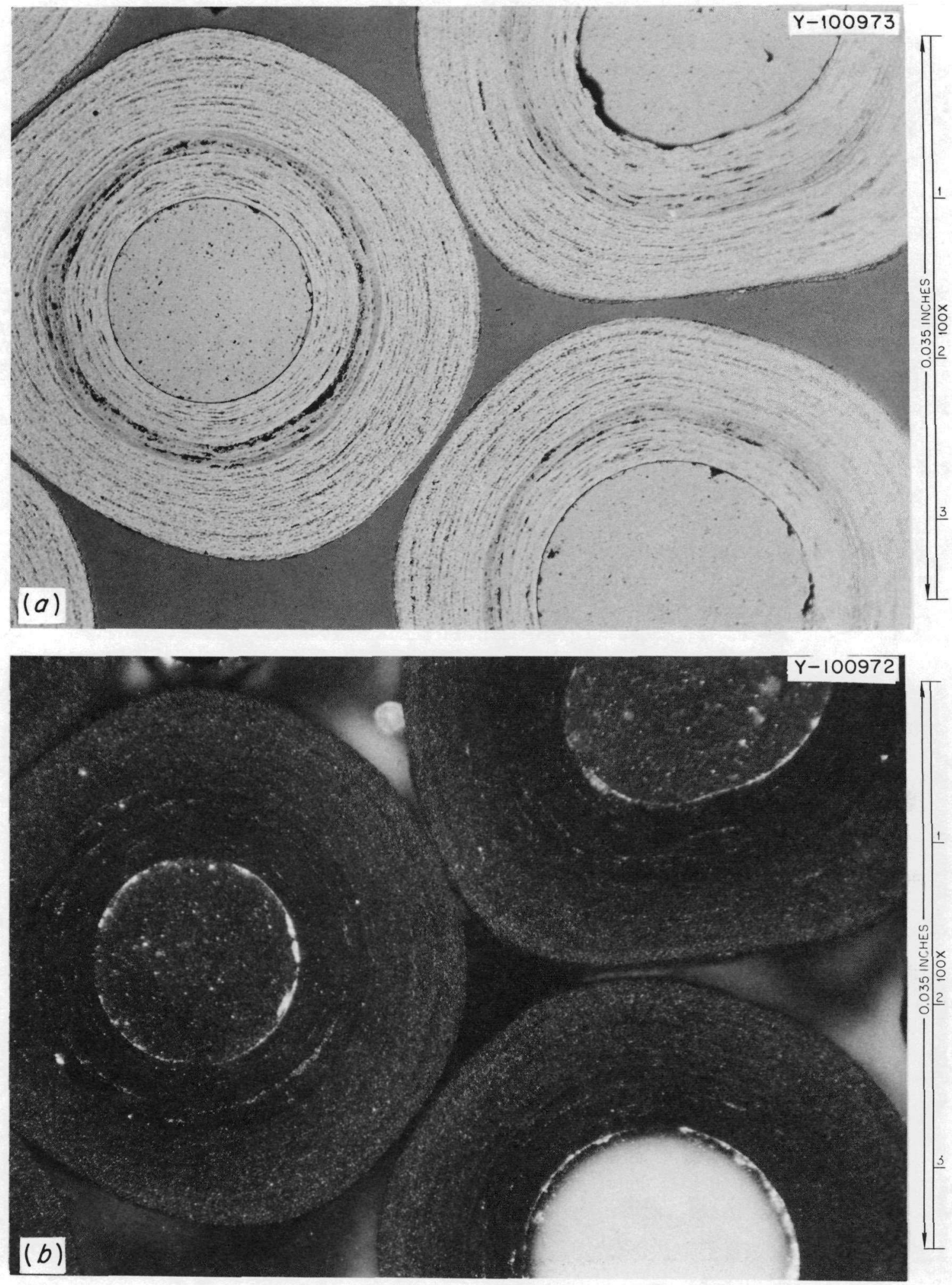

Fig. 15. Unirradiated (2.2Th, $)_{2} \mathrm{O}_{2}$ particles. (a) Bright field. (b) Polarized light. Note the large amount of porosity in the outer coatings. 

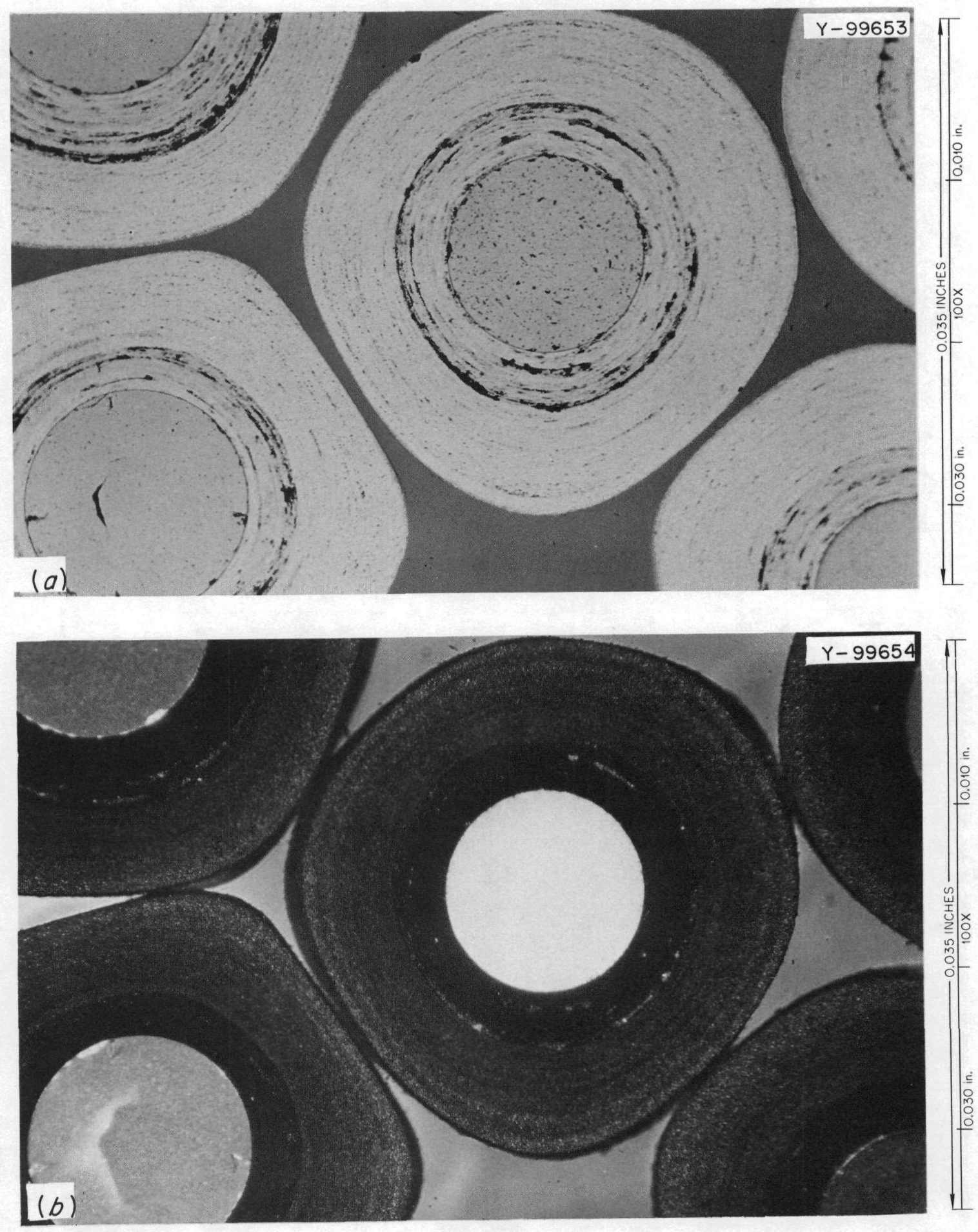

Fig. 16. Unirradiated (4.1Th, $\mathrm{U}_{2} \mathrm{O}_{2}$ Particles. (a) Bright field. $(b)$ polarized light. 


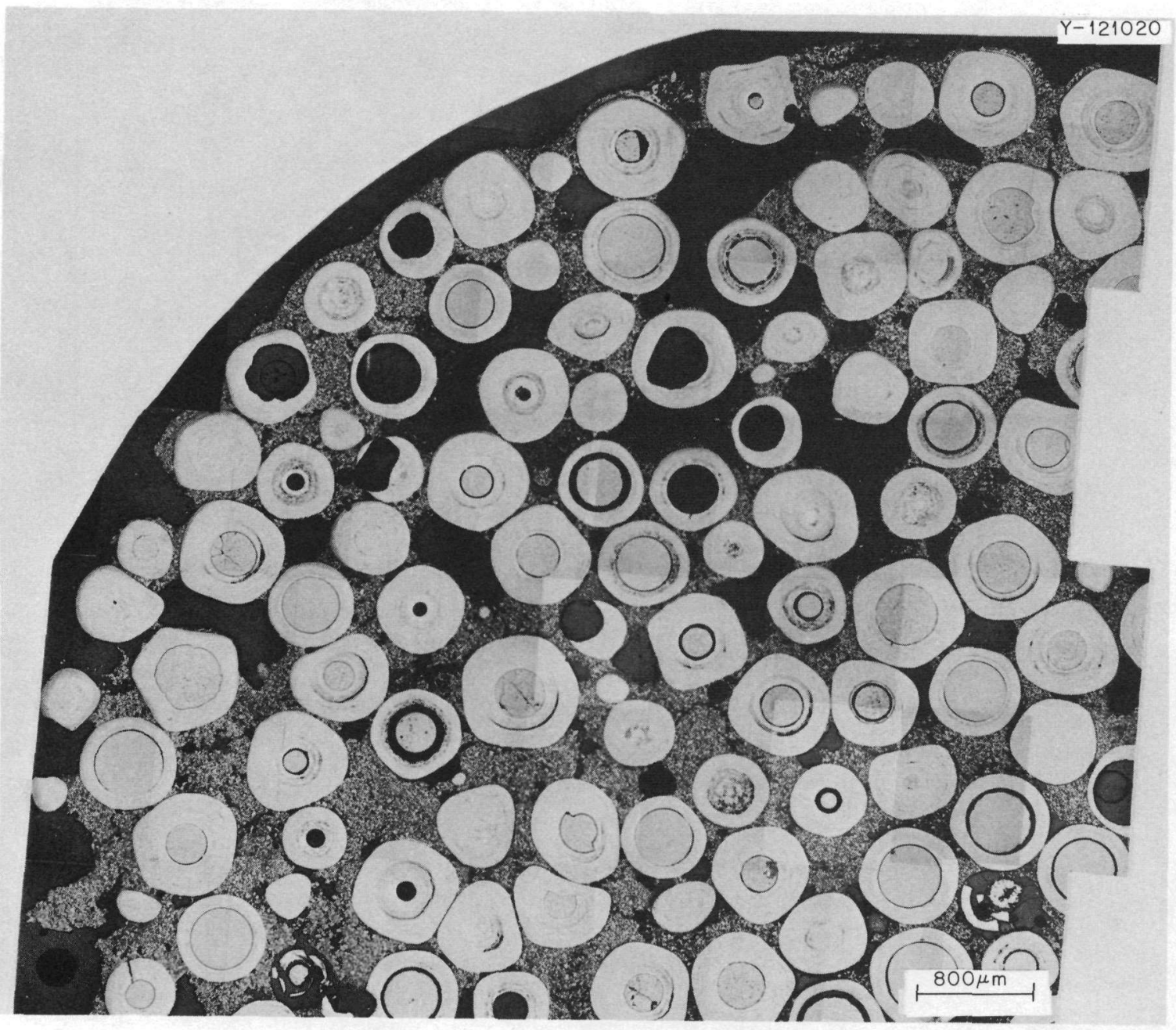

Fig. 17. Radial section of rod H-1-4, which contained Biso-coated (4.1Th, $\mathrm{U}_{2} \mathrm{O}_{2}$ and Biso-coated $\mathrm{ThO}_{2}$ particles and operated at a maximum surface temperature of $1030^{\circ} \mathrm{C}$ and a maximum center-line temperature of $1420^{\circ} \mathrm{C}$. 

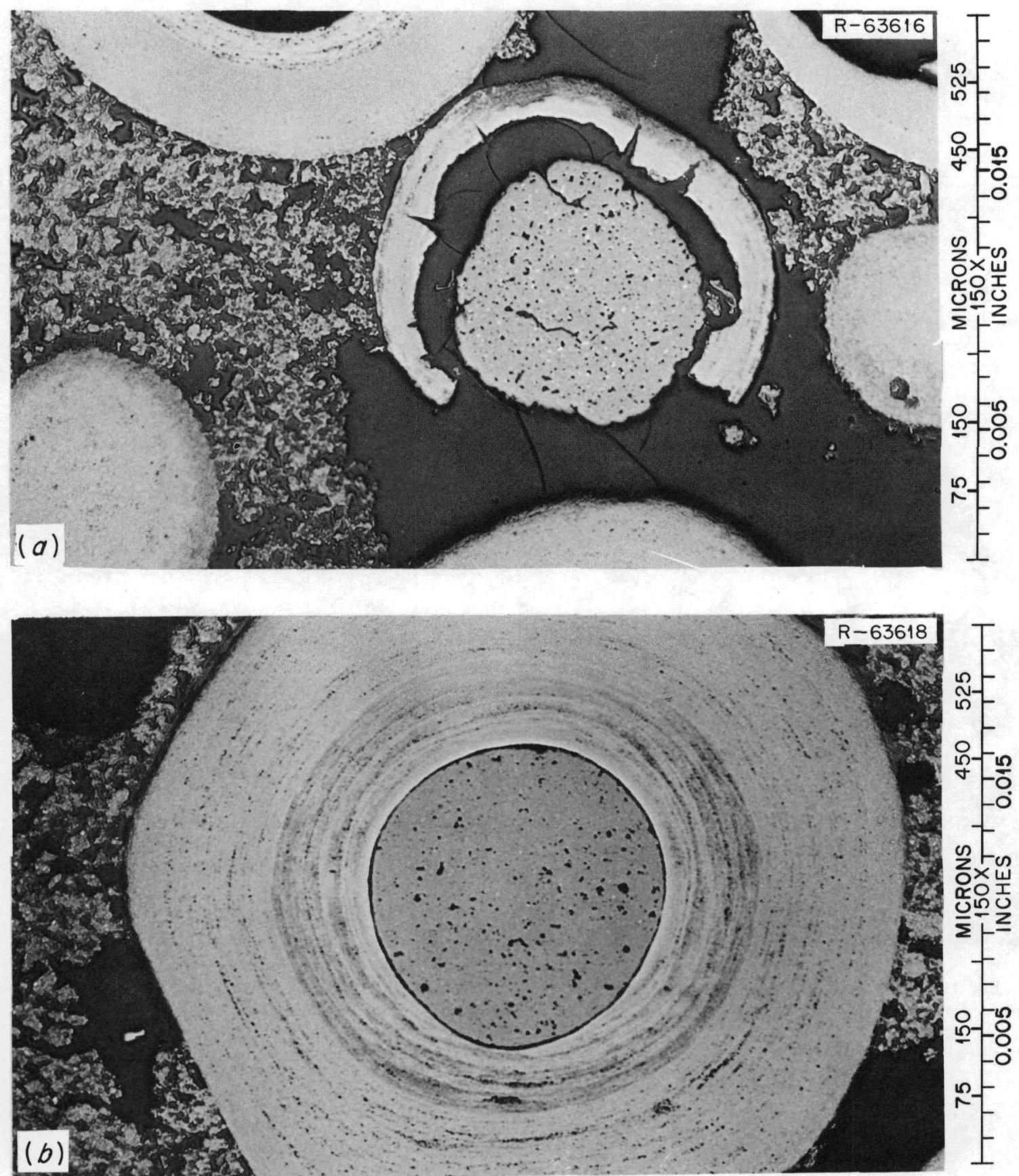

Fig. 18. (4.1Th, $\mathrm{U}) \mathrm{O}_{2}$ particles irradiated in rod H-1-4. (a) Particle with an outer coating that failed because of fabrication without a buffer layer. $(b)$ Particle irradiated at a maximum temperature of $1050^{\circ} \mathrm{C}$ in a temperature gradient of $1200^{\circ} \mathrm{C} / \mathrm{cm}$. Note the small amount of kernel migration. 


\section{Metallography of Fuel Samples That Operated at Very High Temperatures during the Last Irradiation Cycle}

The rods that operated at very high temperatures during the last cycle and were examined metallographically are $\mathrm{H}-1-10, \mathrm{H}-1-12, \mathrm{H}-2-10, \mathrm{H}-2-11$, and $\mathrm{H}-2-12$. These rods include all particle types except the resin-derived UOS particles and the carbide particles. In addition to these rods, a sample from loose bed H-1-6 was also examined metallographically.

A section of rod H-1-12 is shown as it appears under bright field in Fig. 19 and polarized light in Fig. 20. The particles near the center of the rod were extensively damaged. The $\mathrm{UO}_{2}$ and $\mathrm{ThO}_{2}$ kernels apparently reacted with the pyrolytic carbon coatings and graphite matrix to form some mixture of carbides, oxides, and large graphite flakes. The powdery material at the center of the rod was lost during sample preparation, thereby leaving a central hole. The $\mathrm{ThO}_{2}$ particles in this rod showed substantial amoeba effect, as shown in Fig. 21 for a particle at midradius of the rod. This $\mathrm{ThO}_{2}$ kernel has migrated through the buffer layer well into the outer pyrolytic carbon coating. The kernel has apparently desintered because of the high temperature, an effect that has been observed for $\mathrm{ThO}_{2}$ out of reactor. ${ }^{33}$ Graphite has precipitated around the periphery of the migrating kernel (except at the leading edge) and to some extent between some of the $\mathrm{ThO}_{2}$ grains within the kernel.

Some of the $\mathrm{UO}_{2}$ kernels in rod $\mathrm{H}-1-12$ had apparently changed composition from $\mathrm{UO}_{2}$ to a mixture of oxide, carbide, and graphite, as shown in Fig. 22 for a particle near the rod surface. The region of the kernel that is white on the bright field view and gray on the polarized light view is a carbide phase, while the white regions on the polarized light view are apparently graphite. The remaining regions are still an oxide phase. Even though the particle shown in Fig. 22 does not appear to have a failed coating, the coating must have failed at a location not in the plane of polish. The kernel could change composition to a carbide phase only if the carbon monoxide in equilibrium with the kernel was released from the particle. The $\mathrm{UO}_{2}$ particles in this sample did not exhibit any clearly defined kernel migration, possibly because of the change in kernel composition at very high temperatures. The coatings of the particles that were not destroyed by chemical interaction are unbroken, indicating that the mechanical performance of the coatings was good.

Because rod H-2-12 was badly fragmented, the only portion suitable for metallography was an intact section at the very end of the rod. Since this rod was in a steep axial flux gradient and since there can be considerable axial heat conduction at the end of the rod, the actual temperatures across the section were lower than calculated for the midplane of the rod. Nevertheless, metallography of this section shows in Fig. 23 that $\mathrm{UO}_{2}$ kernels migrate considerably more than $\mathrm{ThO}_{2}$ kernels under the same thermal conditions.

A section of rod H-2-11 taken parallel to the rod axis is shown in Figs. 24 and 25. The section was taken about halfway between the rod center-line and the rod surface, so that the center of the rod was damaged more than indicated in Fig. 25. In addition to the severe damage at the center of the rod, some particles at the rod surface were apparently chemically attacked, as shown in Fig. 26. Some of the $\mathrm{ThO}_{2}$ kernels migrated up the temperature gradient, as in Fig. 27. A $(2.2 \mathrm{Th}, \mathrm{U}) \mathrm{O}_{2}$ kernel that migrated well into the outer pyrolytic carbon layer is shown in Fig. 28. This kernel still appears to be an oxide, but another $(2.2 \mathrm{Th}, \mathrm{U}) \mathrm{O}_{2}$ kernel (Fig. 29), which operated at higher temperatures but exhibited less migration, has apparently changed to a carbide.

33. C. S. Morgan, K. H. McCorkle, and G. L. Powell, "Sintering and Desintering of Thoria," pp. 293-99 in Mater. Sci. Research (3rd Int. Conf. Sintering and Related Phenomena), vol. 6, ed. by G. C. Kuczynski, Plenum, New York, 1973. 


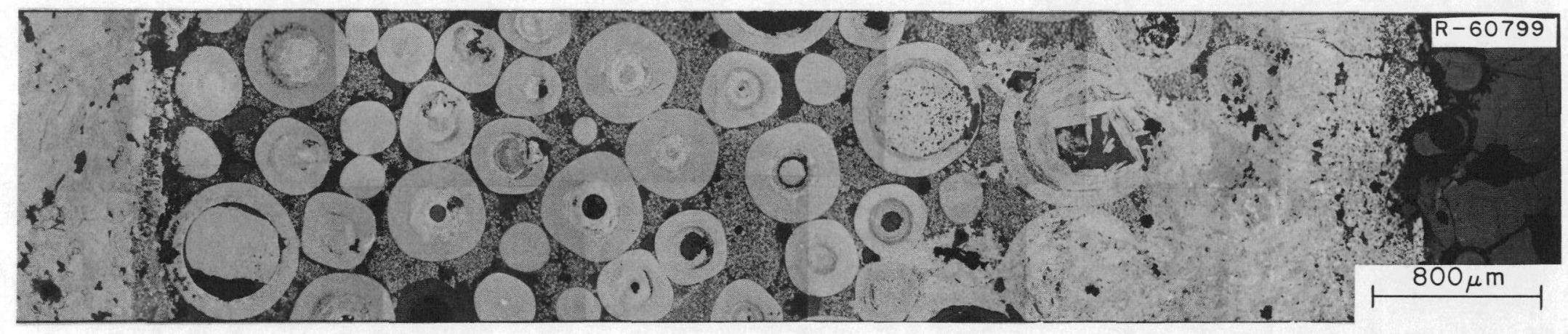

Fig. 19. Metallographic radial section of rod $\mathrm{H}-1-12$. This rod contained Biso-coated $\mathrm{UO}_{2}$ and Biso-coated ThO $\mathrm{O}_{2}$ particles and operated at a maximum surface temperature of $1880^{\circ} \mathrm{C}$ and maximum center-line temperature of $2570^{\circ} \mathrm{C}$. Note at the left the graphite sleeve attached to the rod and at the right the central hole. 


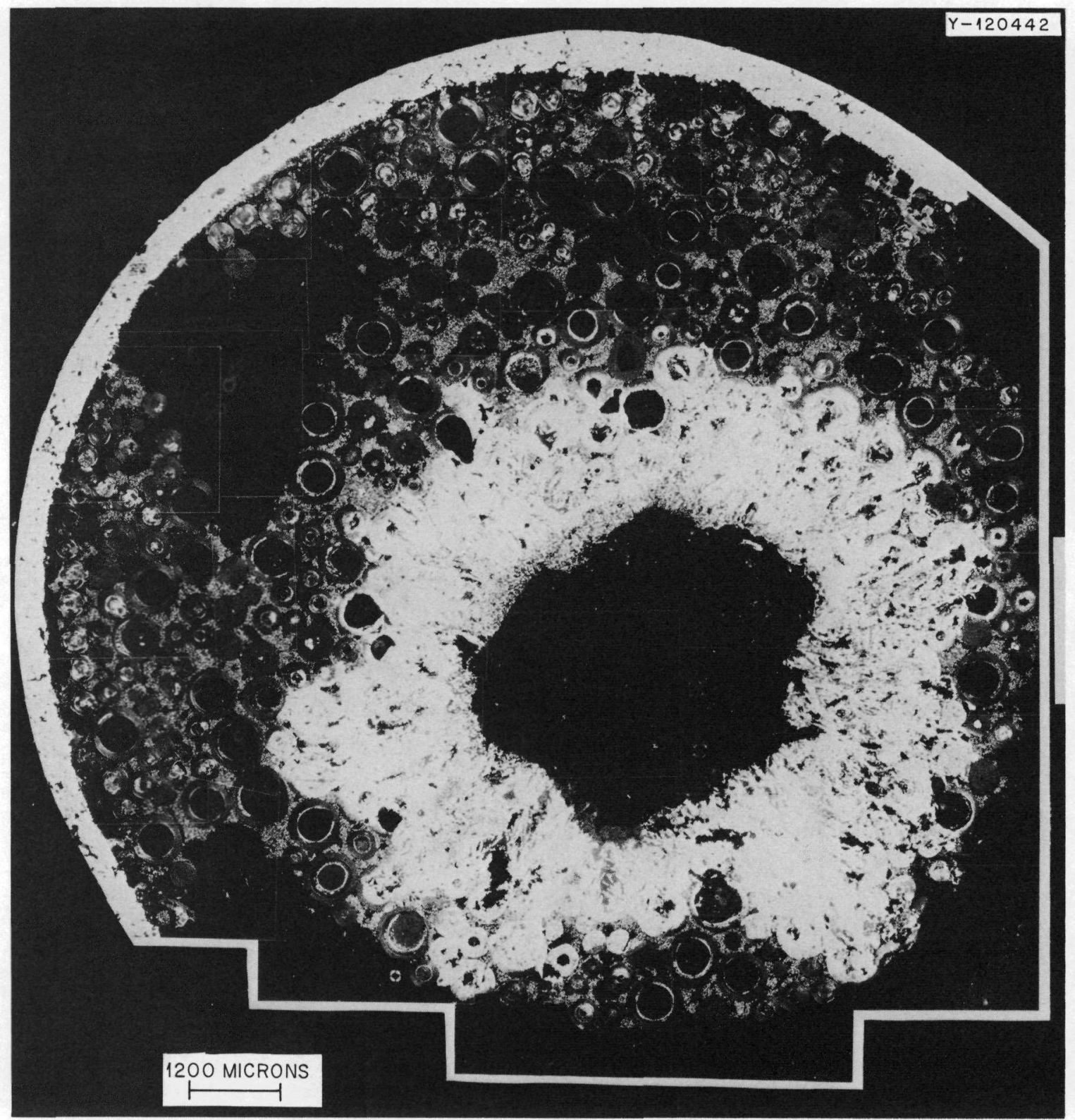

Fig. 20. Diametral section of rod H-1-12 under polarized light. Note the central core and the extensively damaged region surrounding it. 

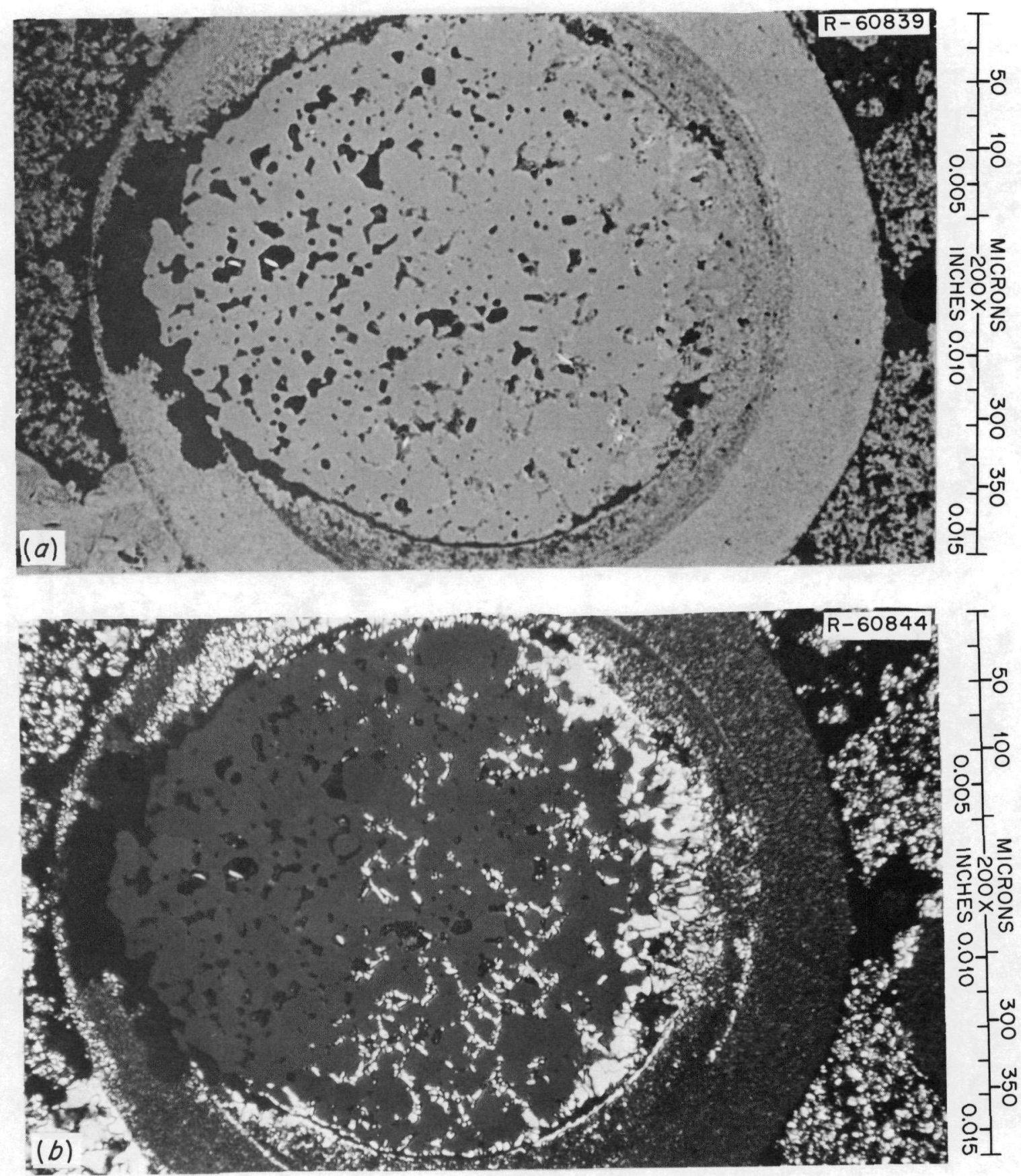

Fig. 21. Biso-coated $\mathrm{ThO}_{2}$ particle irradiated in rod $\mathrm{H}-1-12$ at a maximum temperature of $2400^{\circ} \mathrm{C}$ in a maximum temperature gradient of $1000^{\circ} \mathrm{C} / \mathrm{cm}$. (a) Bright field. (b) Polarized light. Note the migration and desintering of the thoria kernel and the deposition of graphite between the thoria grains and at the periphery of the kernel. 

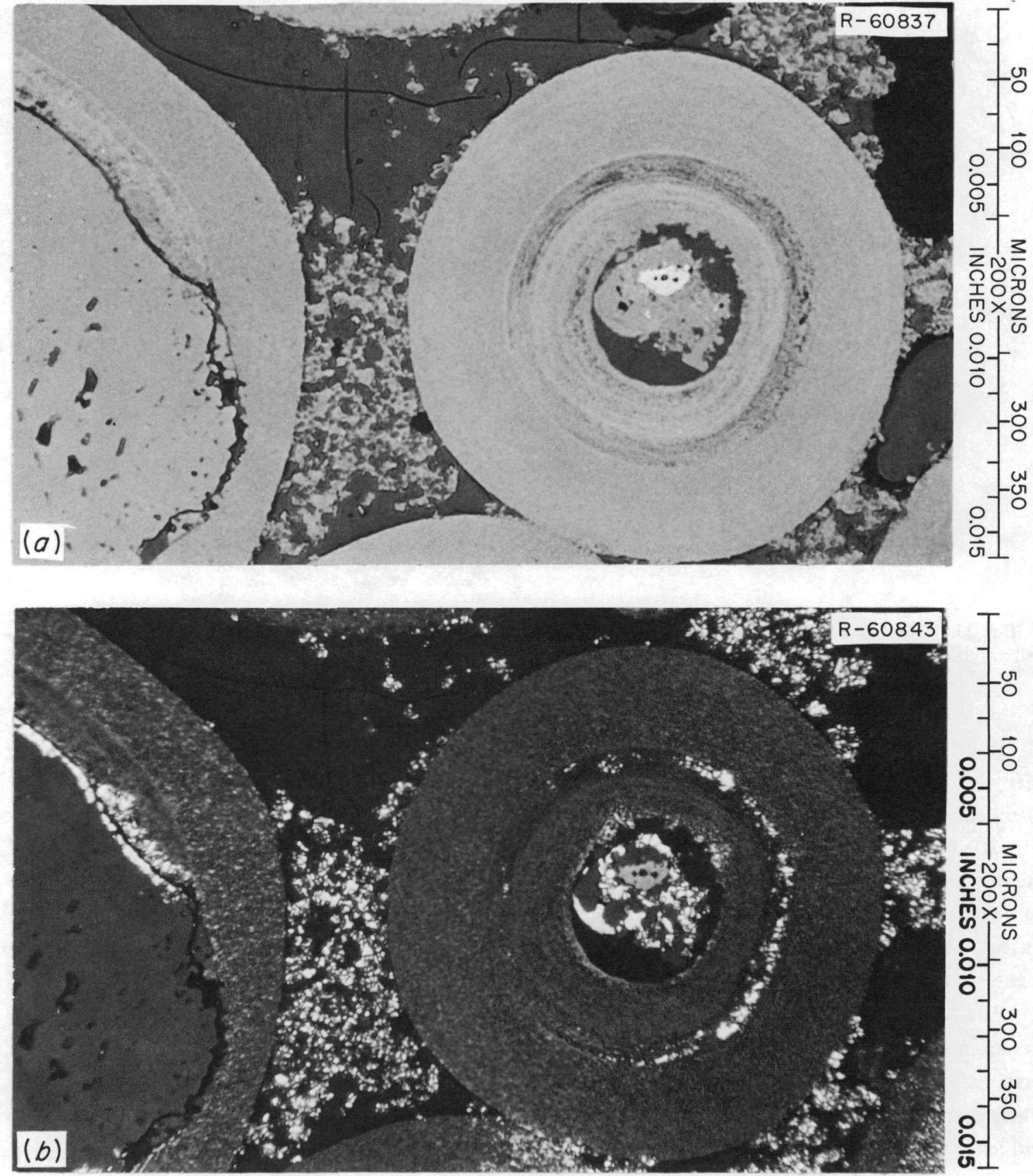

Fig. 22. Biso-coated $\mathrm{UO}_{2}$ particle irradiated in rod $\mathrm{H}-1-12$ at a maximum temperature of $2000^{\circ} \mathrm{C}$ in a maximum temperature gradient of $1600 \mathrm{C} / \mathrm{cm}$. (a) Bright field. (b) Polarized light. Note the change of the kernel composition from $\mathrm{UO}_{2}$ to a mixture of uranium oxide, carbide, and graphite. 


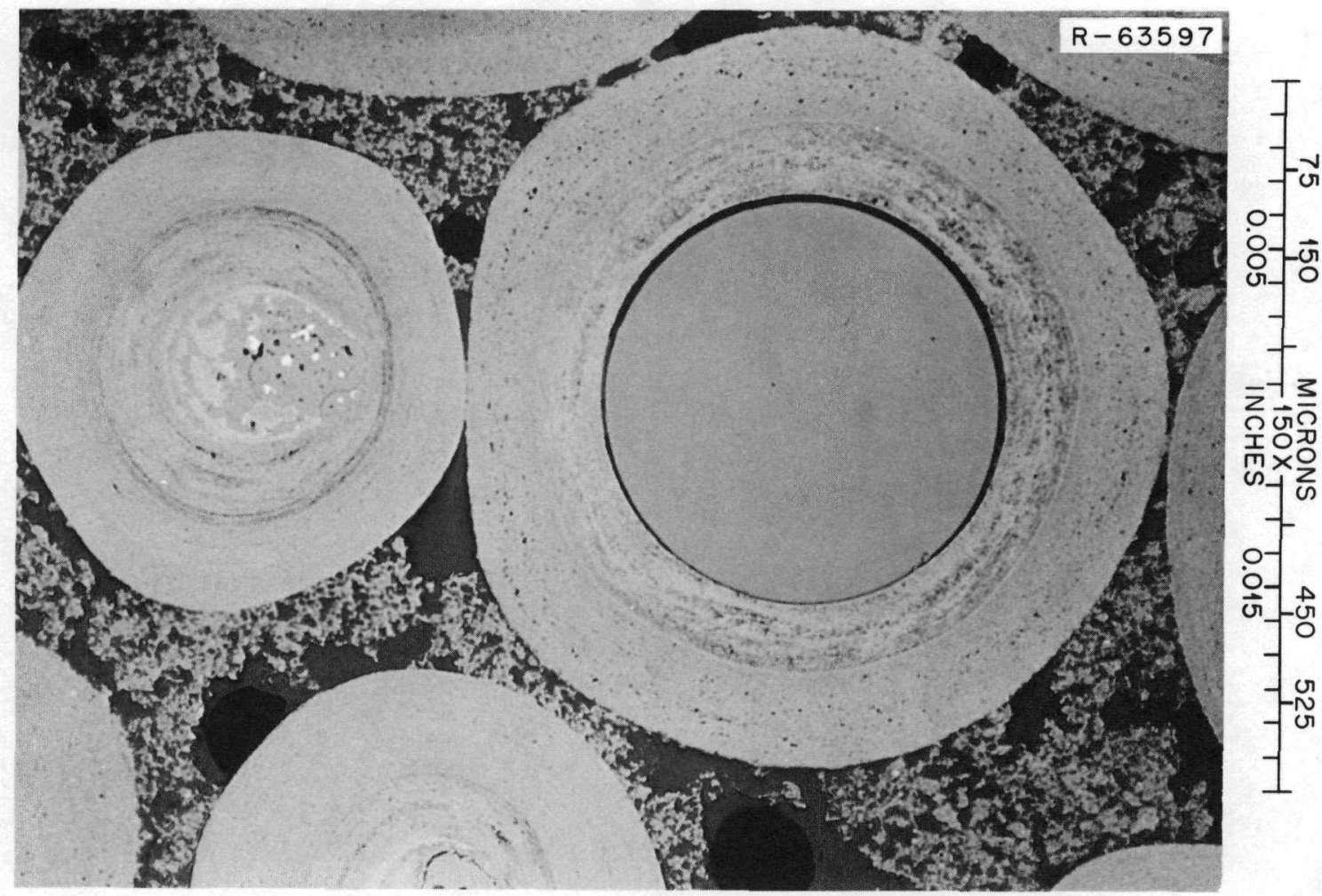

Fig. 23. Biso-coated $\mathrm{UO}_{2}$ particle and $\mathrm{ThO}_{2}$ particle irradiated in rod $\mathrm{H}-2-12$. Note migration of the $\mathrm{UO}_{2}$ kernel (left) well into the buffer layer, while no migration of the $\mathrm{ThO}_{2}$ kernel (right) is observed.

Rod H-1-10 was severely damaged during the irradiation at very high temperature, as shown in Fig. 30 . Many of the particle coatings at the outer surface of the rod were apparently attacked by oxidizing chemical species released from the failed central particles. A portion of the graphite sleeve (upper left of Fig. 30) was bonded to the fuel rod by a deposit released from the damaged rod. The distance between the graphite sleeve and the fuel rod at this location is approximately 25 mils, which indicates that the average gap between the fuel rod and the graphite sleeve at the beginning of the last irradiation cycle was probably at least 13 mils (assuming there was no gap at the side of the rod opposite from where the 25-mil gap was measured). The $\mathrm{ThO}_{2}$ particles that remained intact during the test showed some amoeba effect, as in Fig. 31. The formation of a graphitic region behind the migrating $\mathrm{ThO}_{2}$ kernel is consistent with a model for kernel migration in which carbon diffuses through the kernel from the hot side to the cold side, where it precipitates out as graphite. The $(4.1 \mathrm{Th}, \mathrm{U}) \mathrm{O}_{2}$ kernels in this rod showed much more migration than the $\mathrm{ThO}_{2}$ particles. The $(4.1 \mathrm{Th}, \mathrm{U}) \mathrm{O}_{2}$ kernel in Fig. 32 has migrated through the outer coating under the influence of the high temperature and high temperature gradient.

As shown in Fig. 33, rod H-2-10 was also badly damaged during the last irradiation cycle. The (4.1Th, U) $\mathrm{O}_{2}$ kernels migrated more than the $\mathrm{ThO}_{2}$ kernels, as shown in Fig. 34. As observed in the other high-temperature rods, the particle coatings at the rod surface were chemically attacked (see Fig. 35).

The temperatures at which the individual particles in the sample from loose bed H-1-6 operated are very uncertain because the radial position of a particular particle cannot be determined and because the calculated temperatures themselves have a large uncertainty. The $(4.1 \mathrm{Th}, \mathrm{U}) \mathrm{O}_{2}$ kernels that evidently operated at low temperatures near the surface were permeated with fission gas bubbles and were 


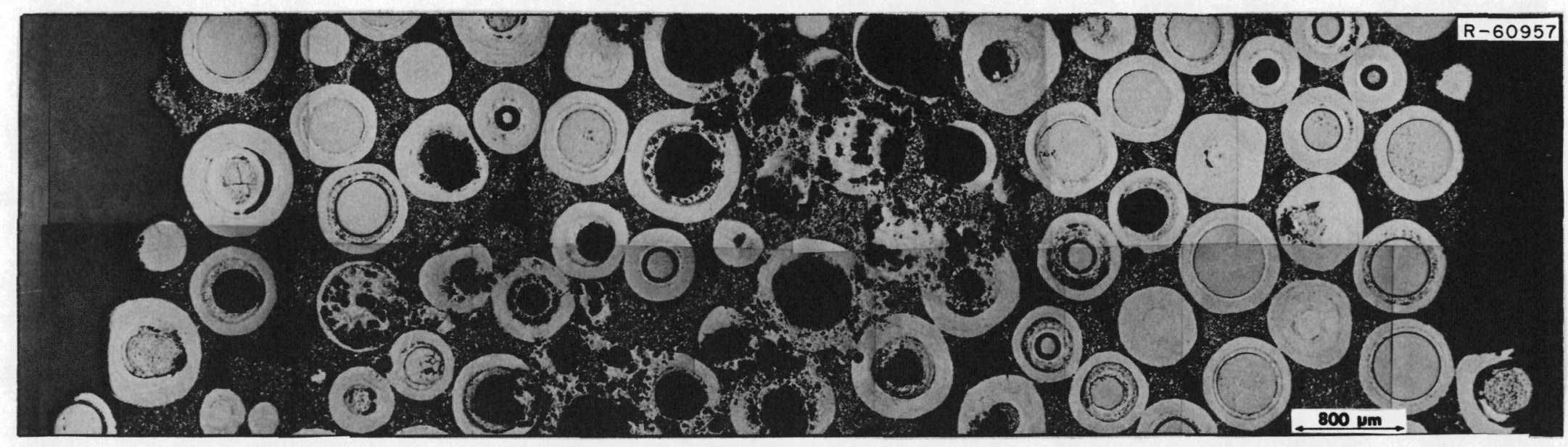

Fig. 24. Diametral section of rod $\mathrm{H}-2-11$. Plane of polish was parallel to the rod axis. The rod contained Biso-coated $(2.2 \mathrm{Th}, \mathrm{U}) \mathrm{O}_{2}$ and $\mathrm{Biso}^{-c o a t e d} \mathrm{ThO}_{2}$ particles and operated at a maximum surface temperature of $1200^{\circ} \mathrm{C}$ and a maximum center-line temperature of $1900^{\circ} \mathrm{C}$. 


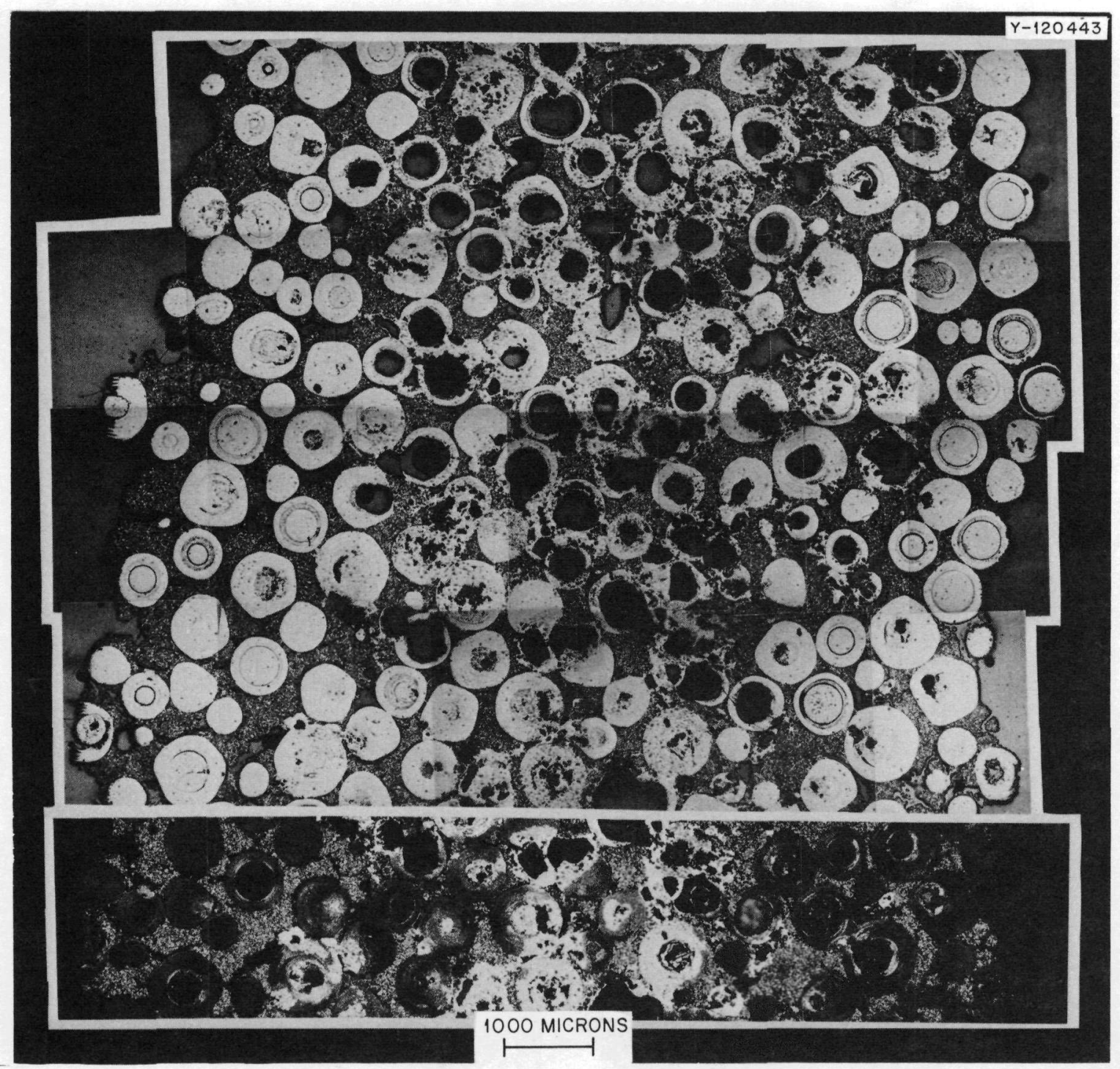

Fig. 25. Low-magnification diametral section of rod H-2-11, used in measuring kernel migration. Top, bright field. Bottom, polarized light.

surrounded by dense carbon recoil zones, as shown in Fig. 36. The (4.1Th, $)_{2} \mathrm{O}_{2}$ particles that operated at much higher temperatures near the center of the sample showed fewer fission gas bubbles and no recoil zones but did show inclusions of metallic fission products (see Fig. 37). The fuel material in these hotter particles evidently diffused into the outer pyrolytic carbon coatings, where it coalesced into small particles. Failures of some particle coatings were observed in this loose particle sample. Some $(4.1 \mathrm{Th}, \mathrm{U}) \mathrm{O}_{2}$ kernels migrated extensively, as shown in Fig. 38. 


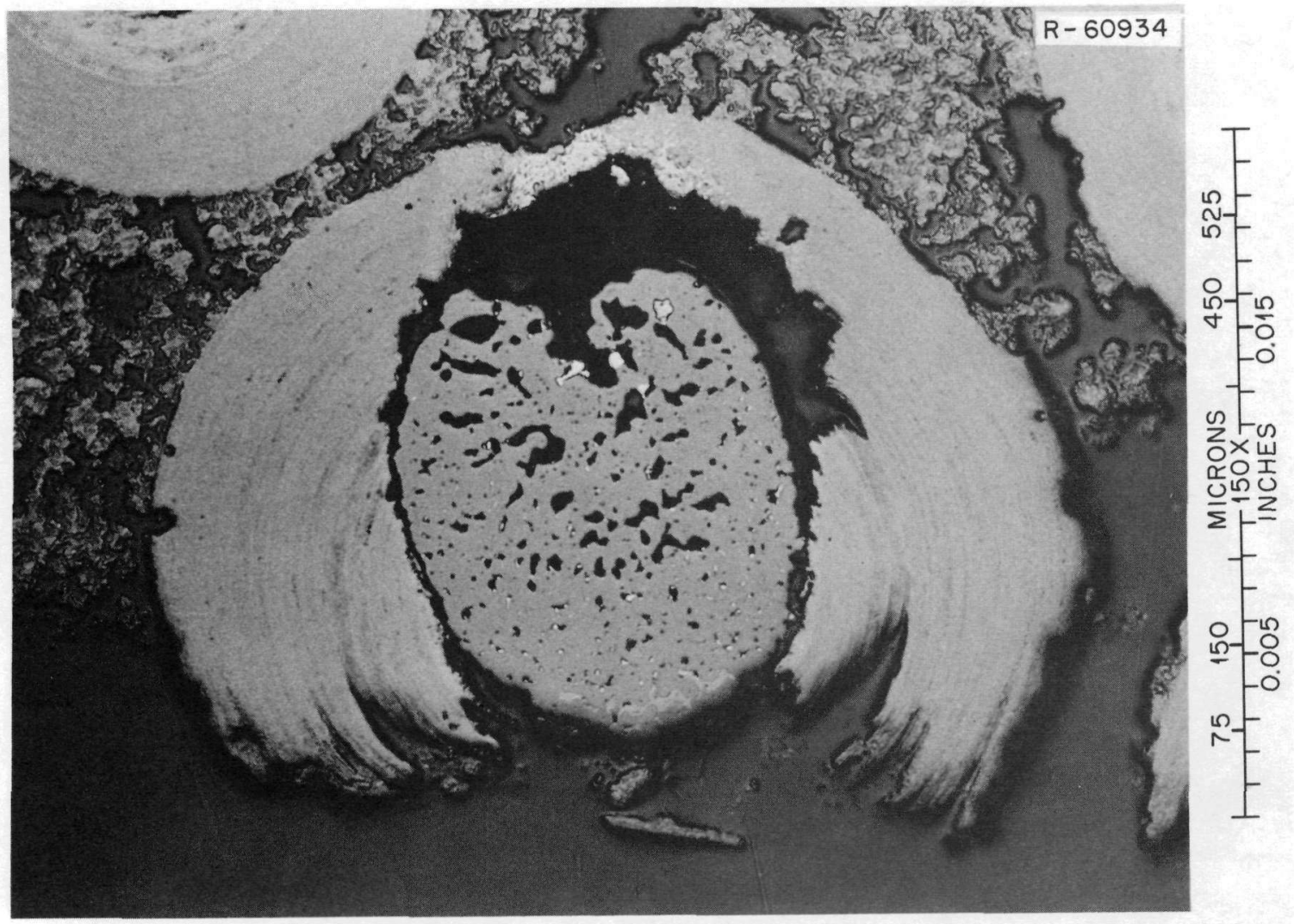

Fig. 26. Damaged (2.2Th, $\mathrm{U}) \mathrm{O}_{2}$ particle at the surface of rod $\mathrm{H}-2-11$

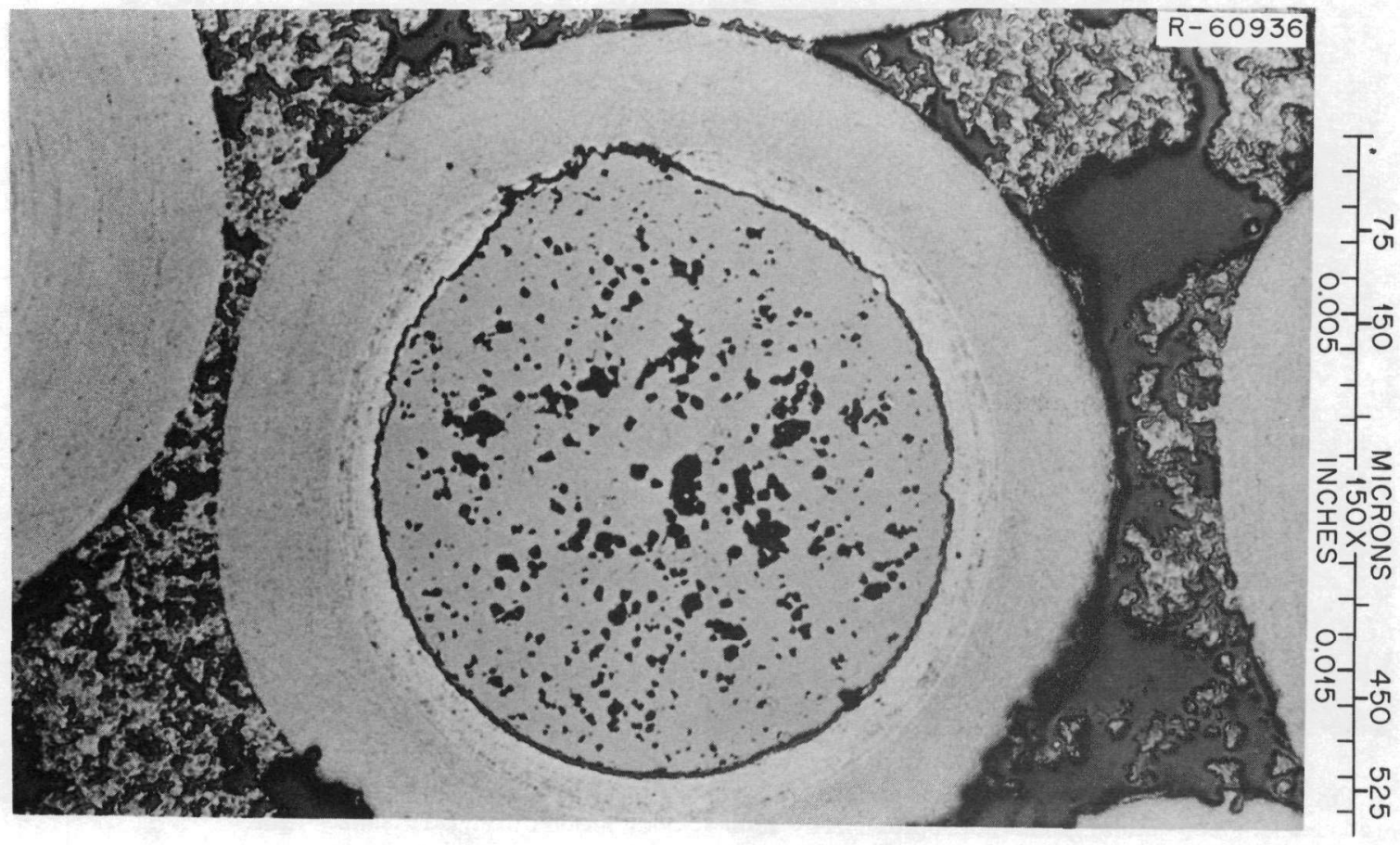

Fig. 27. Migrating $\mathrm{ThO}_{2}$ kernel in rod $\mathrm{H}-2-11$. Maximum temperature and temperature gradient during the last cycle were approximately $1300^{\circ} \mathrm{C}$ and $2000^{\circ} \mathrm{C} / \mathrm{cm}$, respectively. 

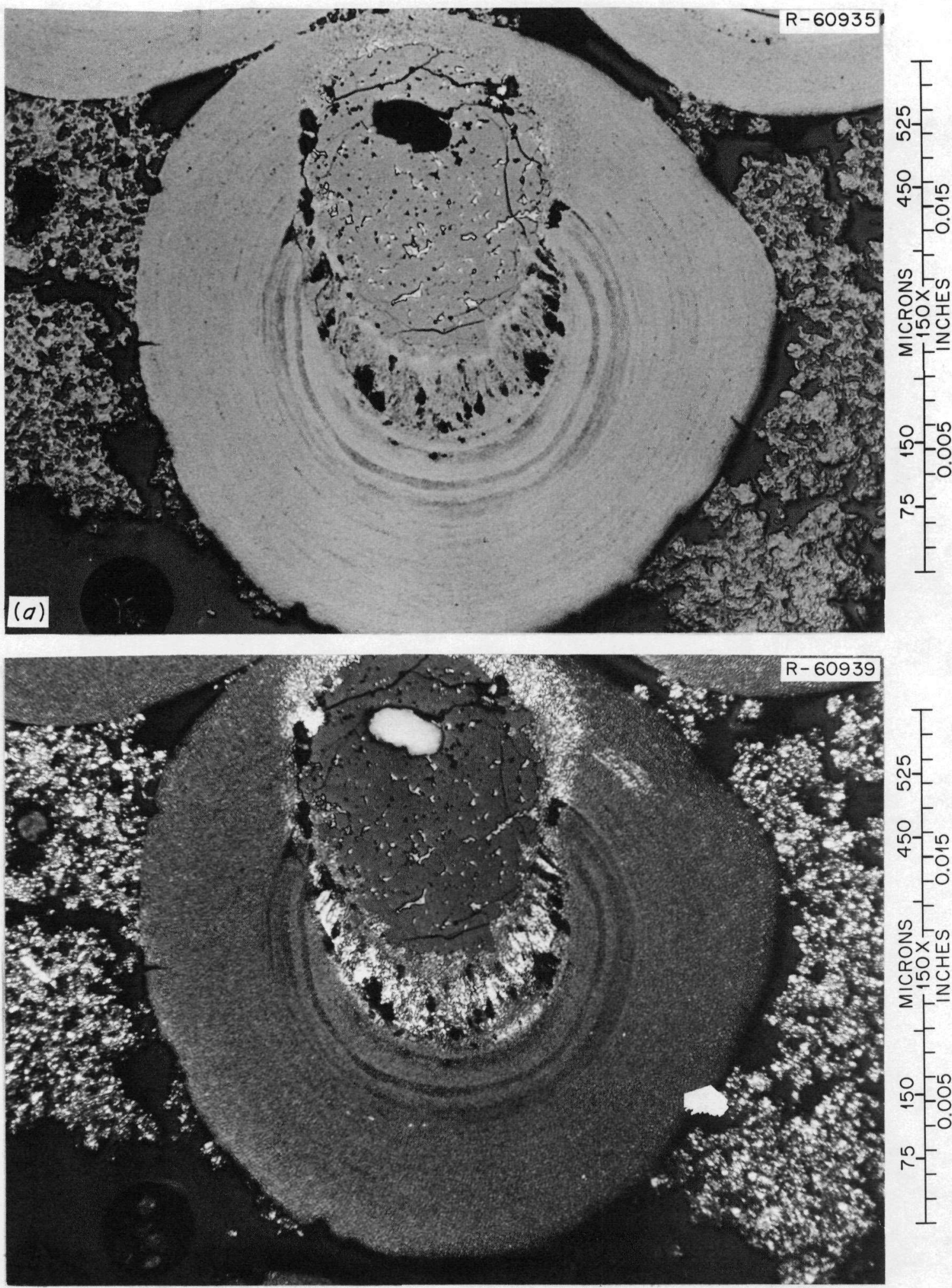

Fig. 28. Migrating (2.2Th, $\mathrm{U}_{2} \mathrm{O}_{2}$ kernel irradiated in rod $\mathrm{H}-2-11$ at a maximum temperature of approximately $1500^{\circ} \mathrm{C}$ in a maximum temperature gradient of approximately $1500^{\circ} \mathrm{C} / \mathrm{cm}$. (a) Bright field. (b) Polarized light. 

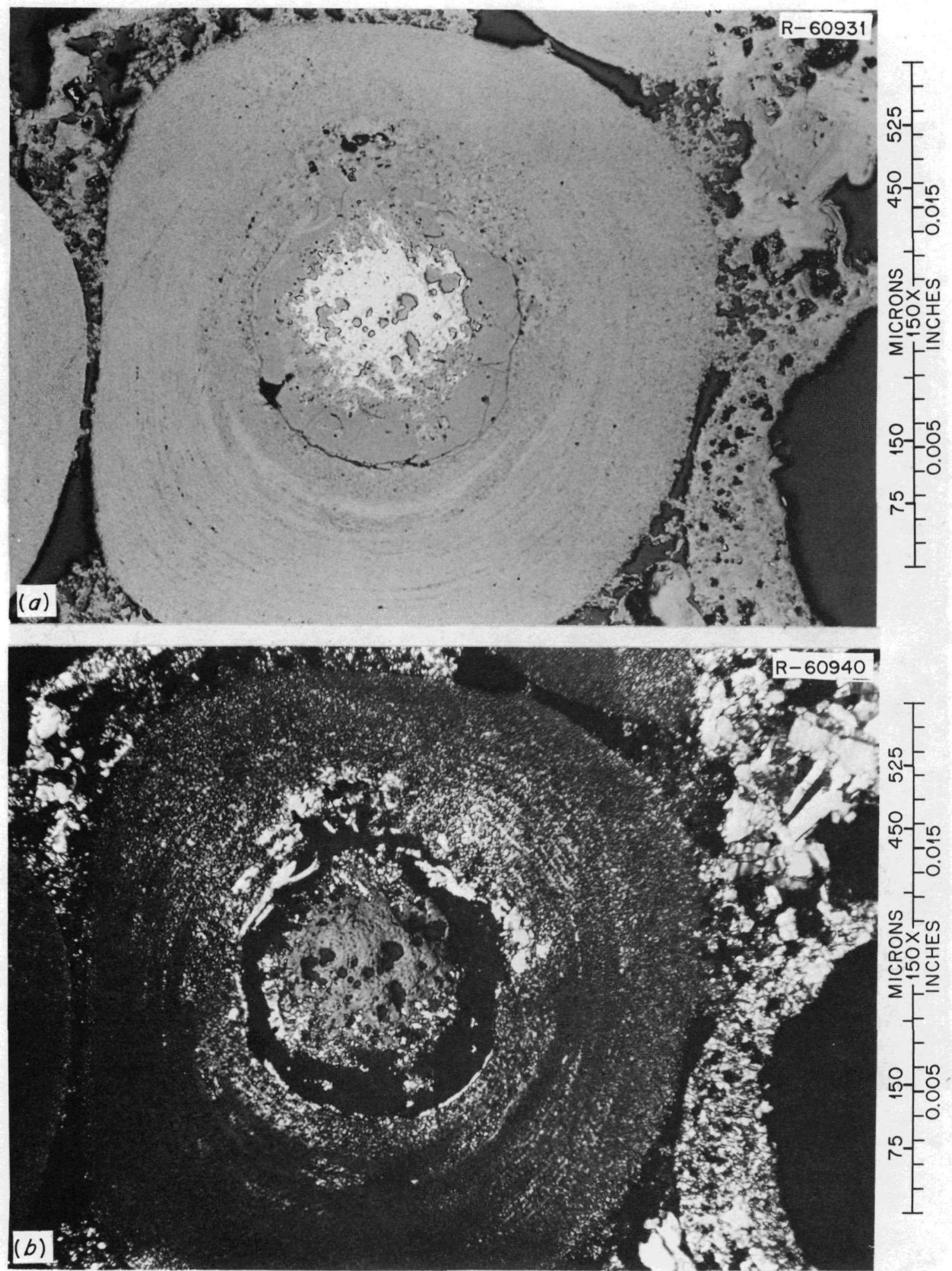

Fig. 29. A (2.2Th, $\mathrm{U}) \mathrm{O}_{2}$ particle irradiated near the midradius of rod $\mathrm{H}-2-11$ at a maximum temperature of approximately $1800^{\circ} \mathrm{C}$ and a temperature gradient of approximately $900^{\circ} \mathrm{C} / \mathrm{cm}$. (a) Bright field. (b) Polarized light. Note the conversion of the oxide kernel to a carbide phase. 


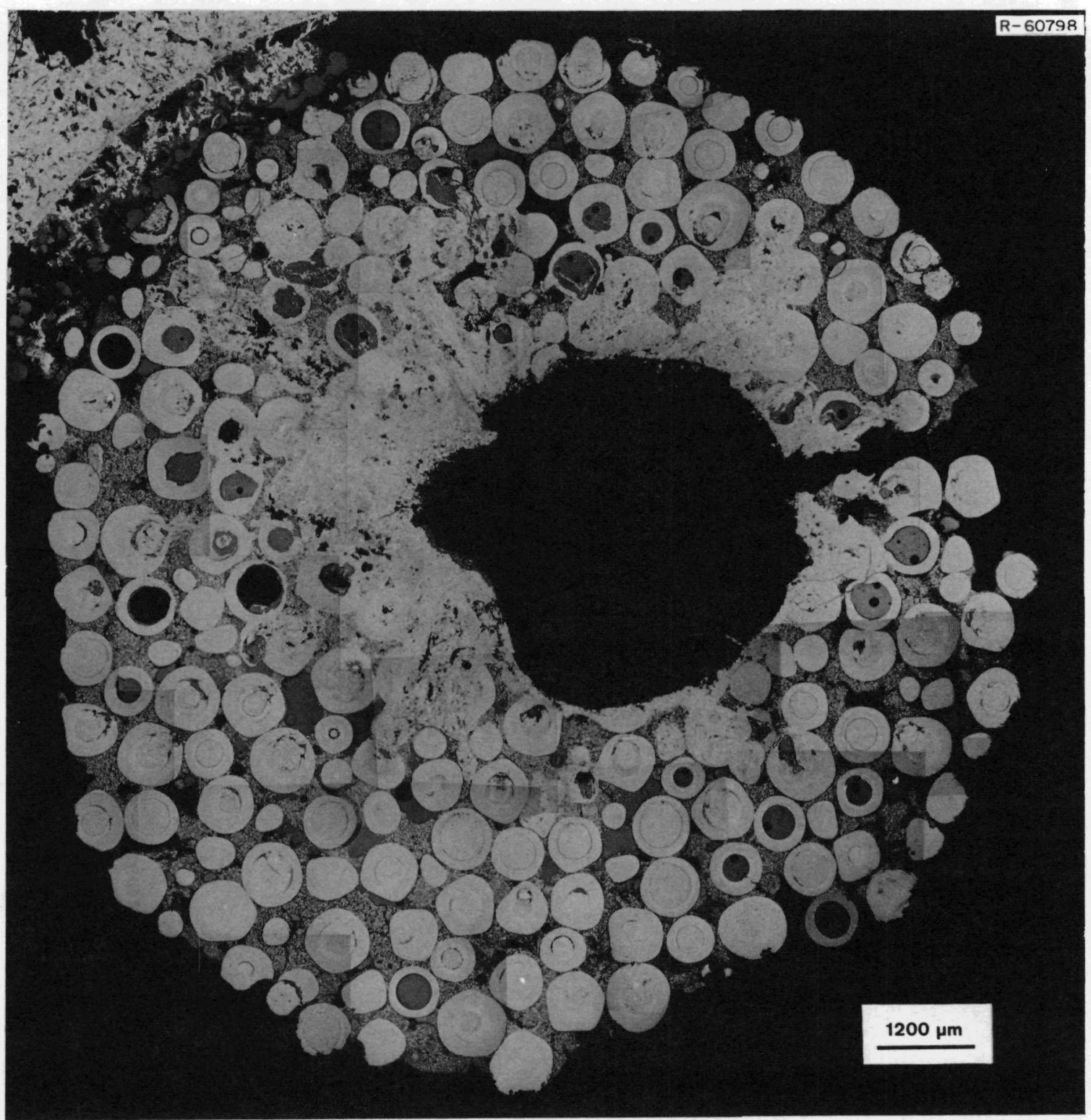

Fig. 30. Diametral section of rod H-1-10, which contained Biso-coated (4.1Th, $\mathrm{U}_{2} \mathrm{O}_{2}$ and Biso-coated $\mathrm{ThO}_{2}$ particles. The maximum surface temperature of the rod was $1500^{\circ} \mathrm{C}$, and the maximum center-line temperature was $2150^{\circ} \mathrm{C}$. Note the extensive damage in the center of the rod. 

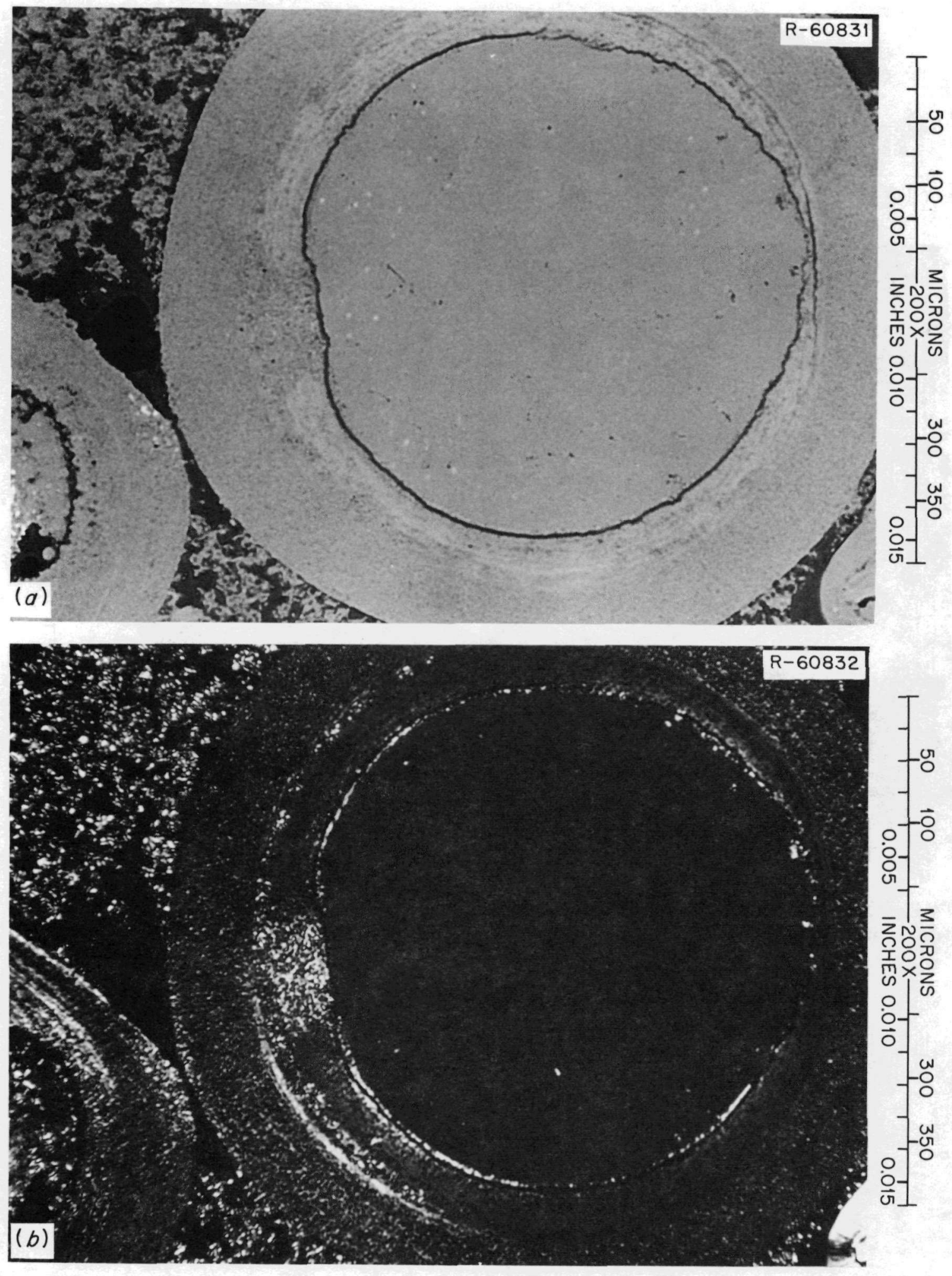

Fig. 31. Migrating $\mathrm{ThO}_{2}$ kernel irradiated in rod $\mathrm{H}-1-10$ at a maximum temperature of $2000^{\circ} \mathrm{C}$ in a maximum temperature gradient of $1100^{\circ} \mathrm{C} / \mathrm{cm}$. (a) Bright field. (b) Polarized light. Note the deposition of graphite behind the migrating kernel. 


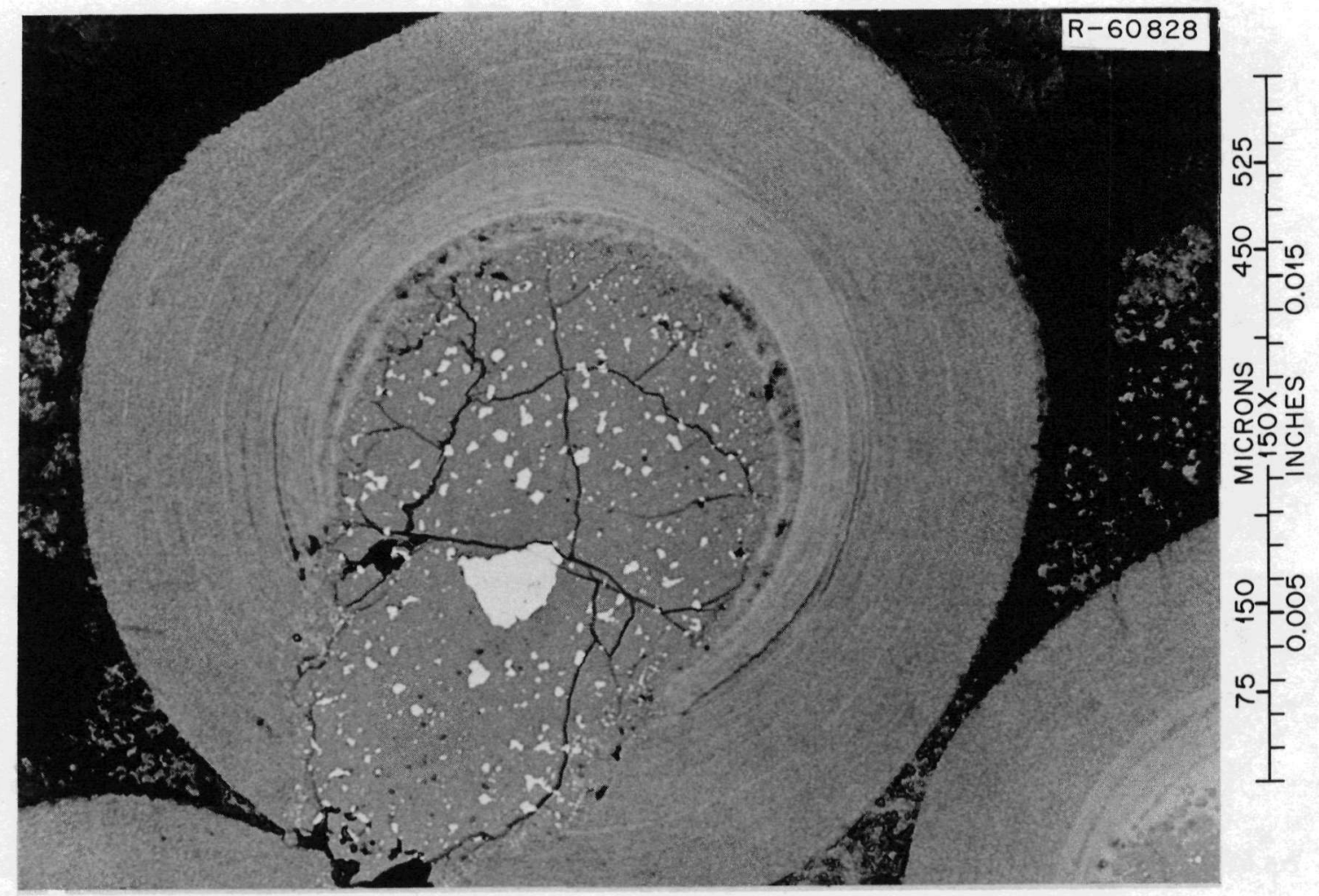

Fig. 32. Migrating (4.1Th, $\mathrm{U}_{2}$ kernel irradiated in rod $\mathrm{H}-1-10$ at a maximum temperature of $1700^{\circ} \mathrm{C}$ in a maximum temperature gradient of $1700^{\circ} \mathrm{C} / \mathrm{cm}$. 


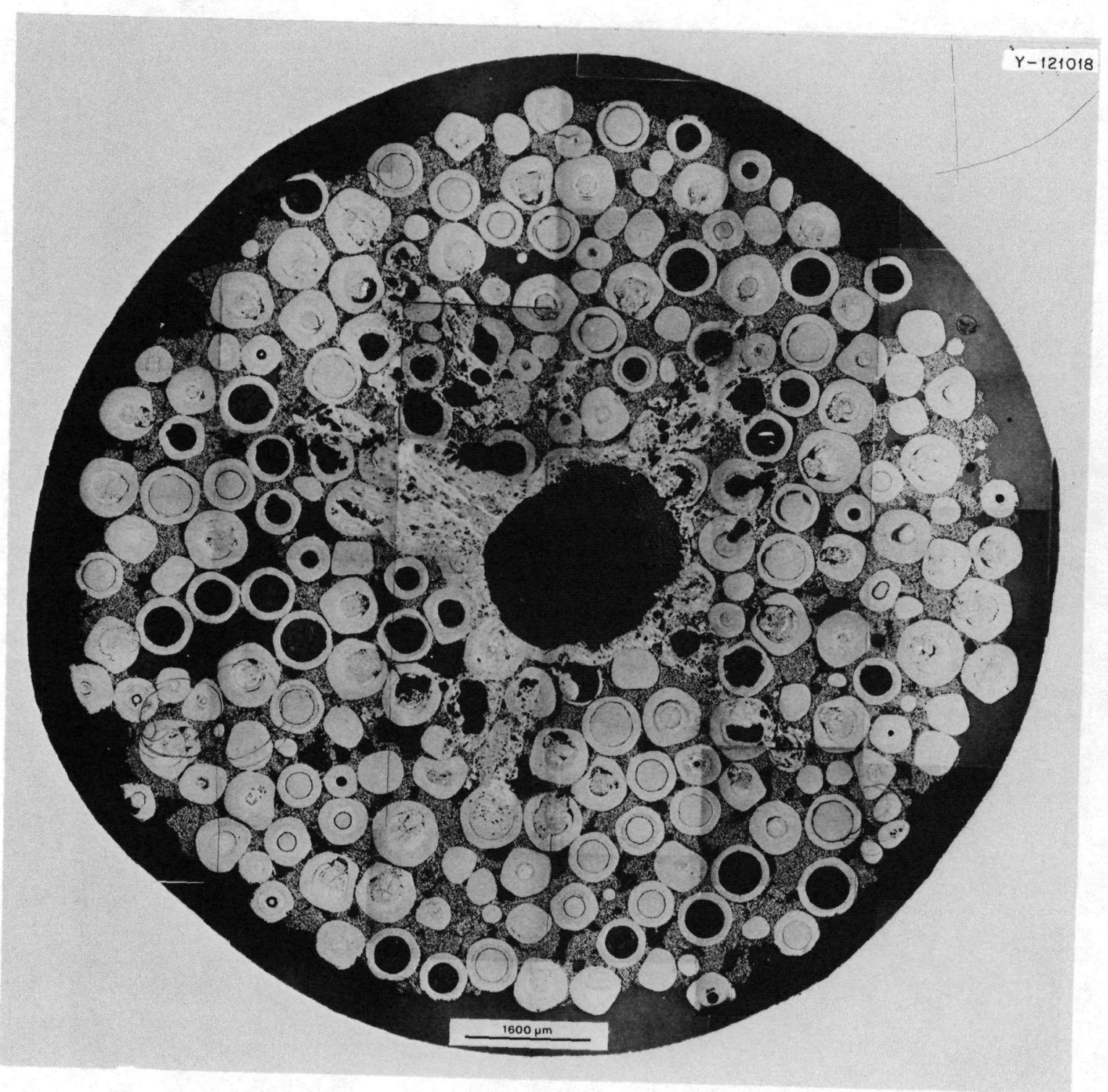

Fig. 33. Diametral section of rod H-2-10, which contained Biso-coated $\left(4.1 \mathrm{Th}, \mathrm{U}^{\circ} \mathrm{O}_{2}\right.$ and Biso-coated $\mathrm{ThO}_{2}$ particles. approximately $1800^{\circ} \mathrm{C}$. 


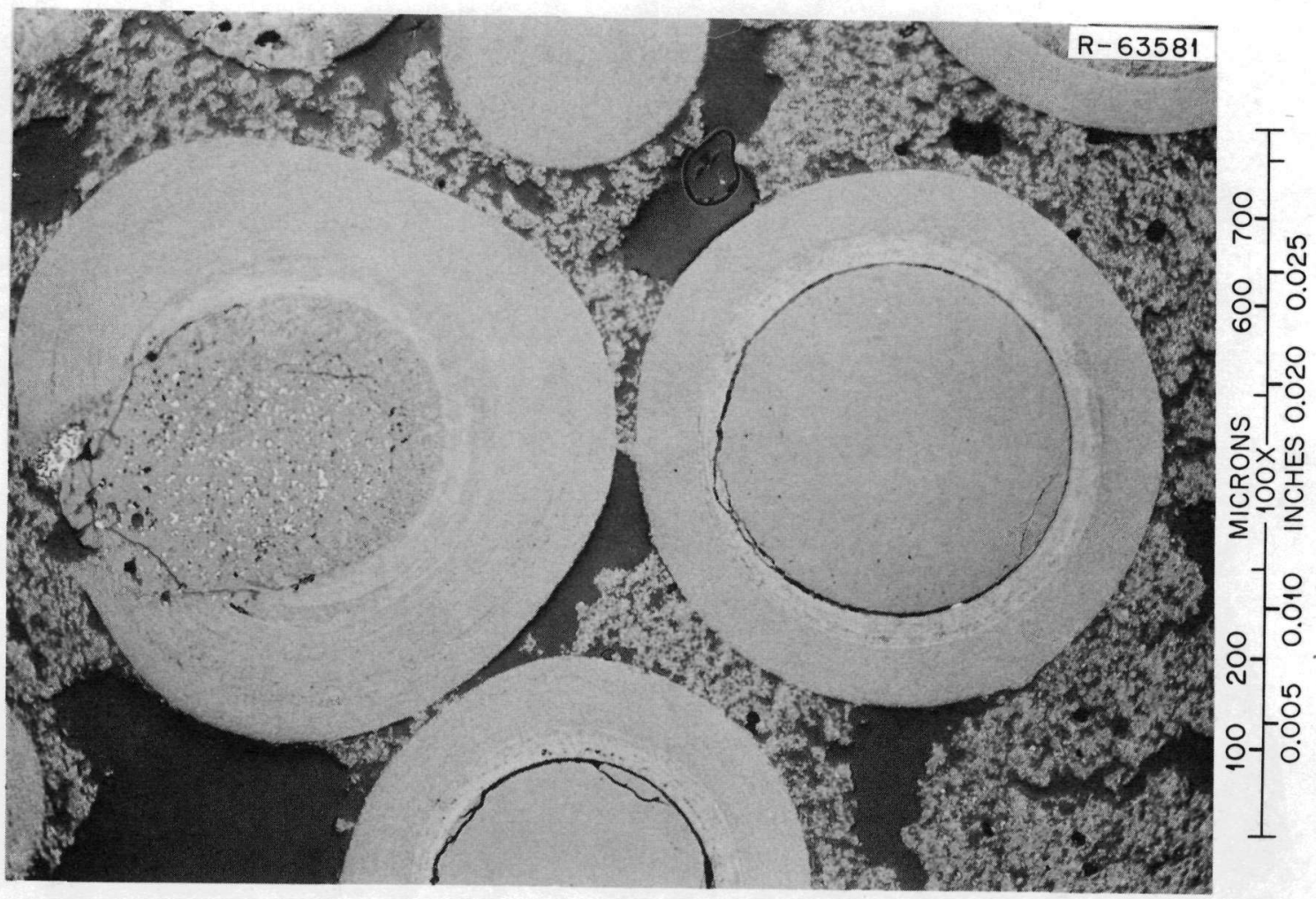

Fig. 34. Biso-coated (4.1Th, $\mathrm{U}) \mathrm{O}_{2}$ particle and $\mathrm{ThO}_{2}$ particle irradiated in rod $\mathrm{H}-2-10$ at a maximum temperature of $1350^{\circ} \mathrm{C}$ in a thermal gradient of $1700^{\circ} \mathrm{C} / \mathrm{cm}$. Note the greater extent of kernel migration in the $(4.1 \mathrm{Th}, \mathrm{U}) \mathrm{O}_{2}$ particle than in the $\mathrm{ThO}_{2}$ particle.

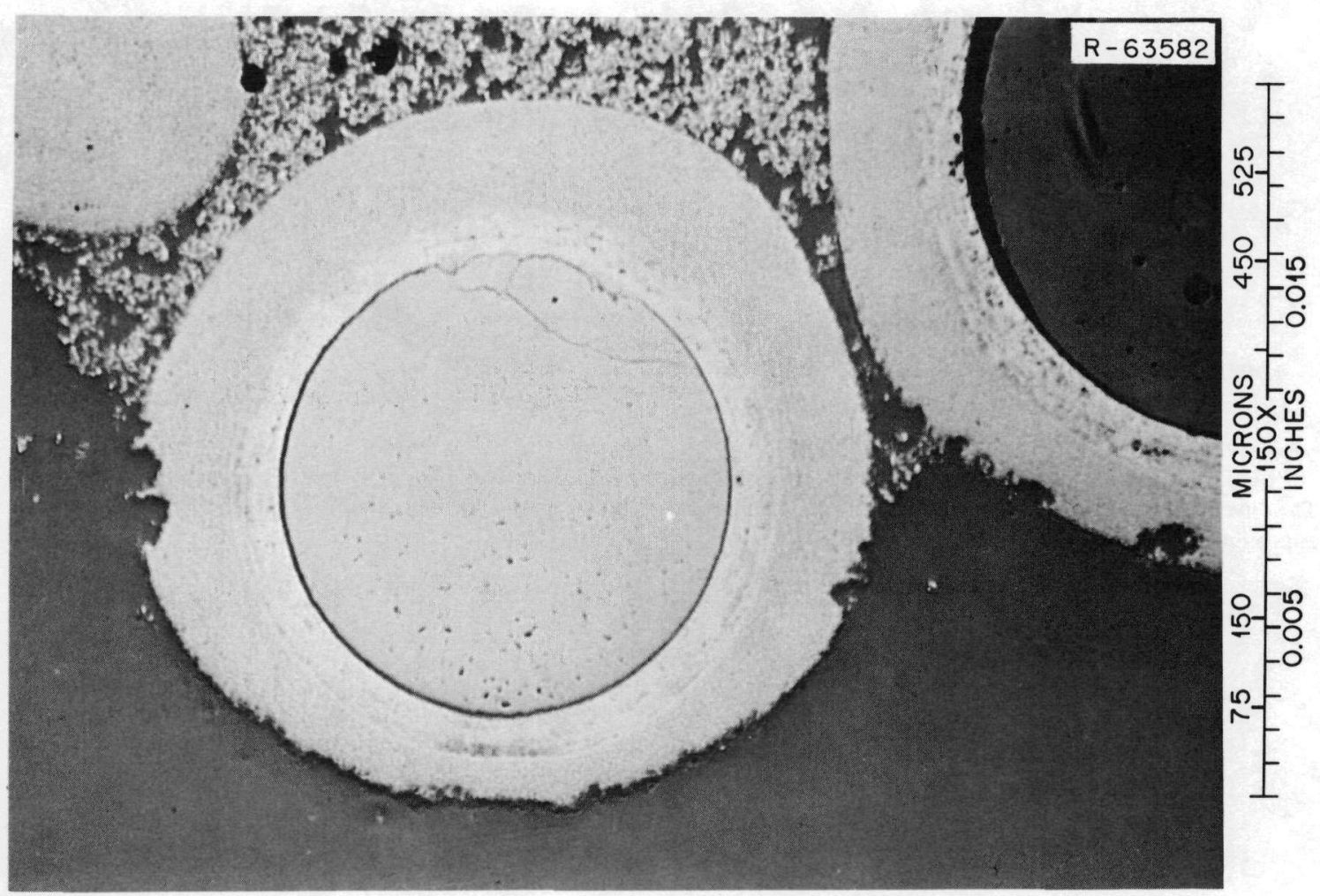

Fig. 35. Particles at the surface of rod H-2-10 showing evidence of chemical attack at the outer surface of the outer pyrolytic carbon coatings. 


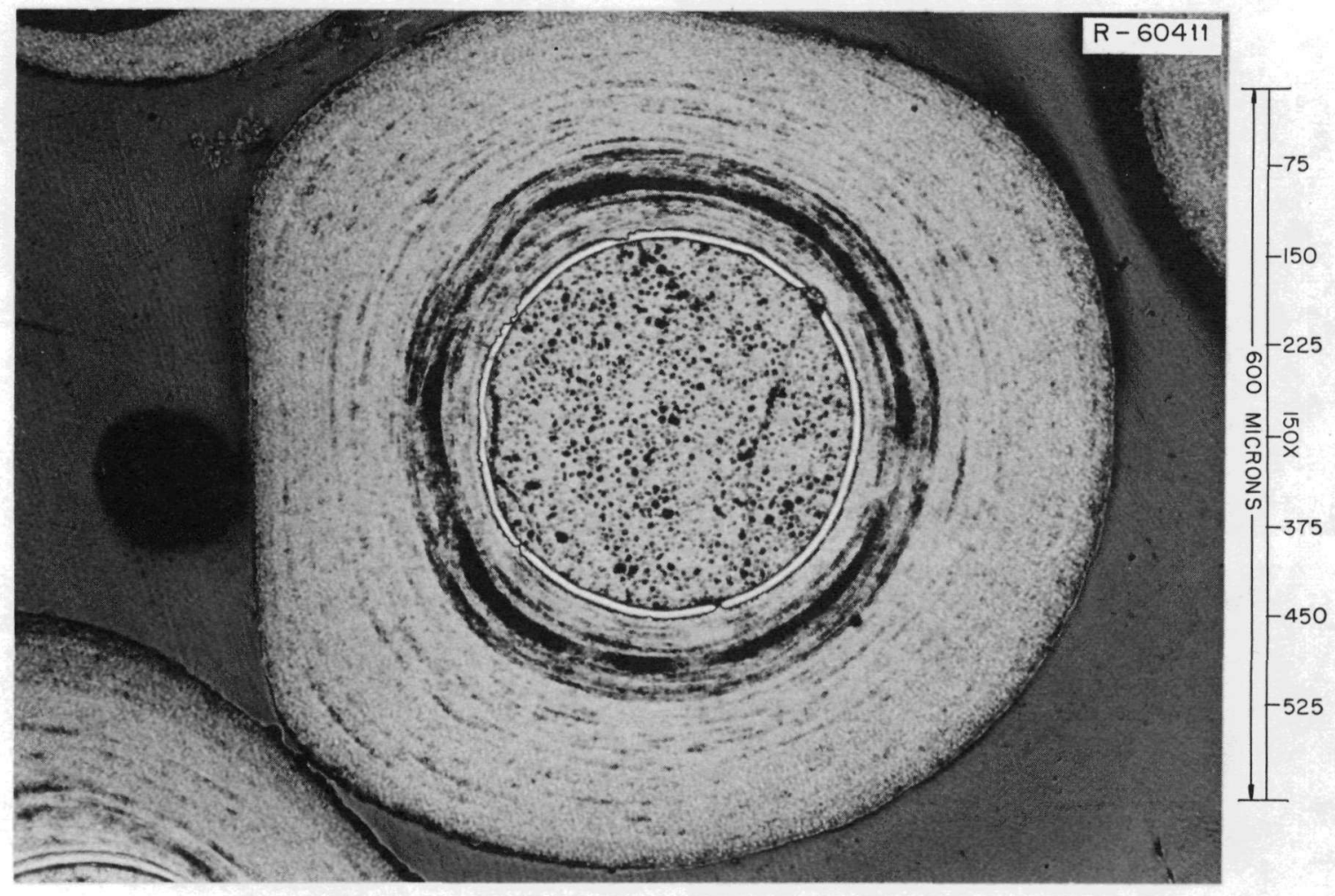

Fig. 36. Loose (4.1Th, U)O $\mathrm{O}_{2}$ particle irradiated near the surface of sample H-1-6. 

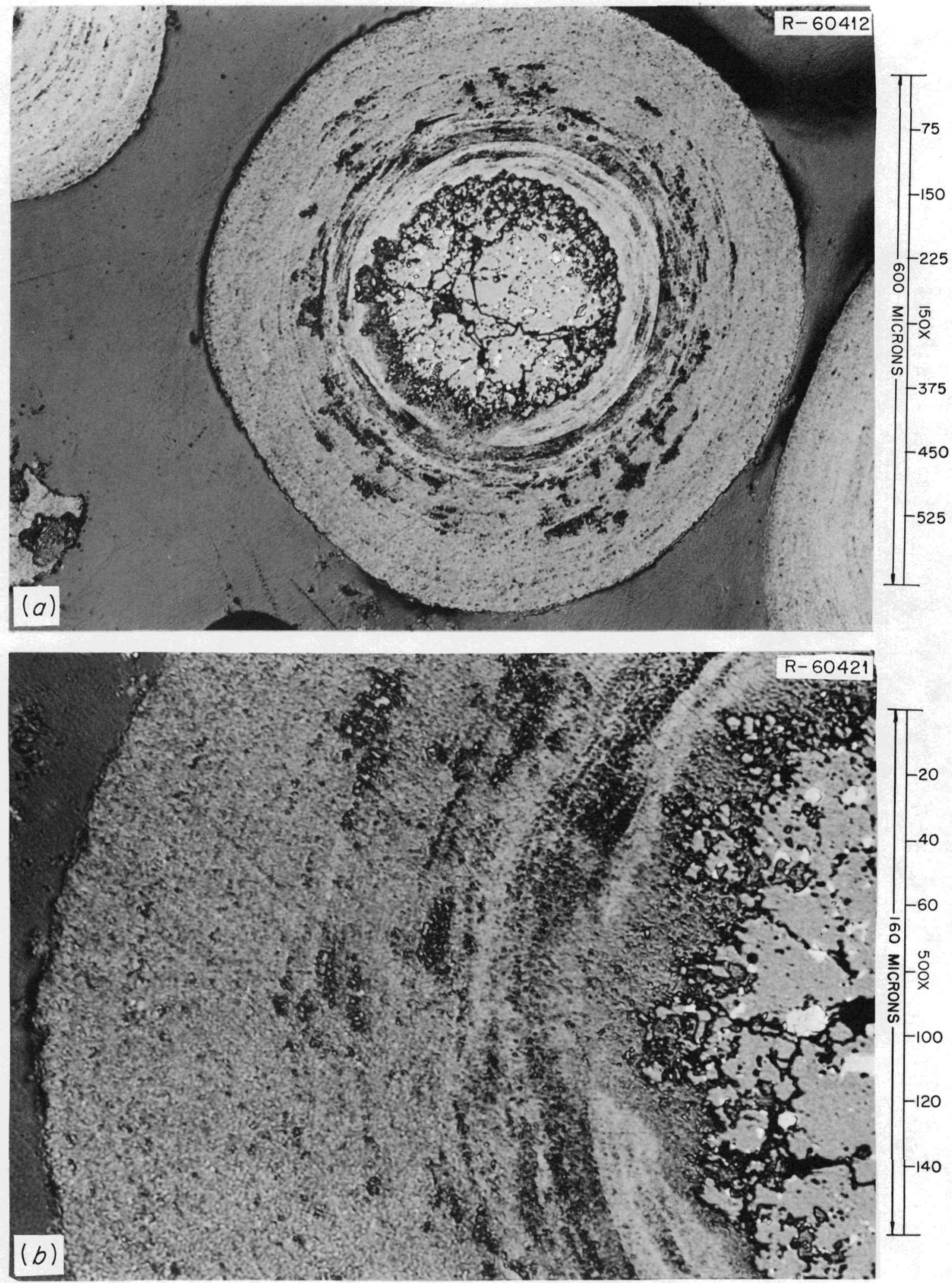

Fig. 37. Loose (4.ITh, $\mathrm{U}_{2} \mathrm{O}_{2}$ particle irradiated near the center in sample H-1-6. (a) Entire particle, showing inclusions of metallic fission products. $(b)$ High magnification of the same particle, showing deposition of fuel material within the outer pyrolytic carbon coating. 


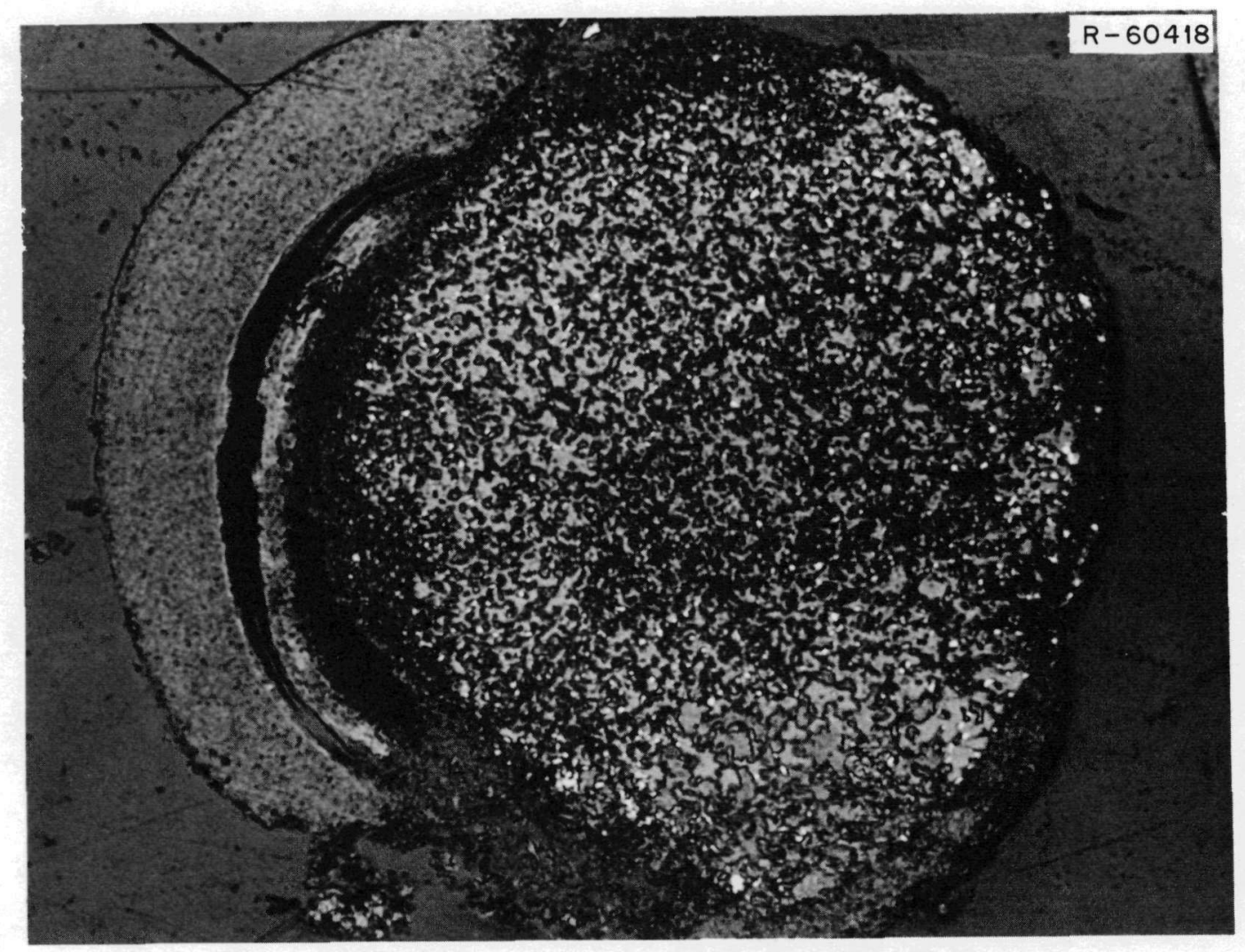

Fig. 38. Extensive kernel migration in a (4.1Th, $\mathrm{U}) \mathrm{O}_{2}$ particle irradiated near the center of sample H-16.

\section{Kernel Migration}

The extent of migration of the different kernel types observed in the various fuel rods is summarized in Table 15. When kernel migration was observed, the maximum migration occurred near midradius in a rod.

Table 15. Extent of kernel migration observed in the various $\mathbf{H}$-capsule fuel rods

\begin{tabular}{|c|c|c|c|c|c|c|c|c|}
\hline \multirow{3}{*}{$\begin{array}{l}\text { Fuel } \\
\text { rod }\end{array}$} & \multirow{3}{*}{$\begin{array}{l}\text { Kernel } \\
\text { type }\end{array}$} & \multirow{2}{*}{\multicolumn{2}{|c|}{$\begin{array}{c}\text { Maximum } \\
\text { temperature }\left({ }^{\circ} \mathrm{C}\right)\end{array}$}} & \multicolumn{3}{|c|}{ Number of particles with - } & \multirow{3}{*}{$\begin{array}{l}\text { Range of observed } \\
\text { kernel migration } \\
\qquad(\mu \mathrm{m})\end{array}$} & \multirow{3}{*}{$\begin{array}{l}\text { Time at } \\
\text { highest } \\
\text { power } \\
\text { (days) }\end{array}$} \\
\hline & & & & \multirow{2}{*}{$\begin{array}{l}\text { Migration } \\
\text { observed }^{a}\end{array}$} & \multirow{2}{*}{$\begin{array}{c}\text { No } \\
\text { migration }^{b}\end{array}$} & \multirow{2}{*}{$\begin{array}{c}\text { Migration } \\
\text { not measurable }\end{array}$} & & \\
\hline & & Center line & Surface & & & & & \\
\hline $\mathrm{H}-1-2$ & $\mathrm{ThO}_{2}$ & 1250 & 890 & 0 & 28 & 0 & $<2$ & 97.1 \\
\hline $\mathrm{H}-1-4$ & $\mathrm{ThO}_{2}$ & 1420 & 1030 & 0 & 6 & 5 & $<2$ & 97.1 \\
\hline $\mathrm{H}-2-10$ & $\mathrm{ThO}_{2}$ & 1800 & 1120 & 16 & 4 & 6 & $4-120$ & 39.3 \\
\hline H-2-11 & $\mathrm{ThO}_{2}$ & 1910 & 1190 & 12 & 1 & 3 & $4-36$ & 39.3 \\
\hline H-1-10 & $\mathrm{ThO}_{2}$ & 2150 & 1480 & 16 & 0 & 4 & $13-62.5$ & 39.3 \\
\hline $\mathrm{H}-1-12$ & $\mathrm{ThO}_{2}$ & 2570 & 1880 & 23 & 0 & 19 & $8-218$ & 39.3 \\
\hline $\mathrm{H}-1-4$ & $(4.1 \mathrm{Th}, \mathrm{U}) \mathrm{O}_{2}$ & 1420 & 1030 & 23 & 5 & 14 & $2-43$ & 97.1 \\
\hline H-2-10 & $(4.1 \mathrm{Th}, \mathrm{U}) \mathrm{O}_{2}$ & 1800 & 1120 & 37 & 1 & 8 & $16-240$ & 39.3 \\
\hline $\mathrm{H}-1-10$ & $(4.1 \mathrm{Th}, \mathrm{U}) \mathrm{O}_{2}$ & 2150 & 1480 & 30 & 0 & 0 & $50-262$ & 39.3 \\
\hline H-2-11 & $(2.2 \mathrm{Th}, \mathrm{U}) \mathrm{O}_{2}$ & 1910 & 1190 & 7 & 0 & Not determined & $60-200$ & 39.3 \\
\hline $\mathrm{H}-1-2$ & $\mathrm{UO}_{2}$ & 1250 & 890 & 79 & 8 & 0 & $3-33$ & 97.1 \\
\hline
\end{tabular}

${ }^{a}$ Does not include particles containing kernels that converted to carbide.

${ }^{b}$ Limit of detection is approximately $2 \mu \mathrm{m}$. Actual migration if any, is less than this.

${ }^{c}$ Because of damage to particles. 
No migration was observed at the center of the rods, where the temperature gradient was zero. In most cases the $\mathrm{ThO}_{2}$ kernels migrated considerably less than the $\mathrm{UO}_{2}$ or mixed oxide kernels. The $\mathrm{UO}_{2}$ kernels appeared to migrate more than the mixed oxide kernels under the same thermal conditions. There was no apparent difference in relative stability between the $(4.1 \mathrm{Th}, \mathrm{U}) \mathrm{O}_{2}$ and $(2.2 \mathrm{Th}, \mathrm{U}) \mathrm{O}_{2}$ kernels.

The correlation of the measured kernel migration with temperature, temperature gradient, and time at power are reported elsewhere ${ }^{34}$ along with details of the kernel migration measurements.

\section{Conclusions}

The results of this irradiation test can be summarized as follows.

1. The fuel rods that operated at normal temperatures $\left(<1450^{\circ} \mathrm{C}\right)$ throughout the test were largely fragmented or debonded, possibly because of the high initial linear heat rates or the repeated thermal cycling during the test.

2. The particle coatings applied in the laboratory and prototype production coaters at ORNL showed excellent irradiation behavior.

3. When rod center-line temperatures exceeded approximately $1800^{\circ} \mathrm{C}$, the rods were extensively damaged at the center, and large amounts of kernel migration were observed.

4. The migration of $\mathrm{UO}_{2}$ and mixed-oxide kernels was considerably greater than that of $\mathrm{ThO}_{2}$ kernels.

5. Even though some rods reached calculated center-line temperatures greater than $2000^{\circ} \mathrm{C}$, the failure of particles not in the centers of the rods was not catastrophic. The bulk of the fuel remained intact even though the central particles converted into a mixture of carbide and graphite phases.

\section{ACKNOWLEDGMENTS}

The authors would like to acknowledge F. J. Furman for applying coatings in the prototype production coater and loading the fuel assemblies, C. B. Pollock for applying coatings in the laboratory coater, and J M Robbins and F. P. Jeffers for characterizing the particles and fabricating the fuel rods. Gulf General Atomic provided the carbide fuel particles. M. K. Preston and J. T. East fabricated the capsules and assured quality control. Bettis Atomic Power Laboratory provided the hafnium-zirconium alloys, and R. G. Donnelly and co-workers fabricated the hafnium sleeves. The Idaho Nuclear Corporation provided information needed for the experiment design and monitored the fluxes during irradiation in the ETR. J. D. Jenkins chose the capsule flux monitors and set up the XSDRN calculations. A special acknowledgment is given to H. T. Kerr for interpreting the flux monitor data and the XSDRN calculations. R. A. Buhl assisted in the postirradiation examination and set up the depletion and heat transfer calculations. Metallography of the irradiated samples was performed by N. M. Atchley, and the electron microprobe analyses were performed by T. J. Henson.

34. T. B. Lindemer and R. A. Olstad, HTGR Fuel Kernel Migration Data for the Th-U-C-O System as of A pril 1, 1974, ORNL-TM-4493 (in preparation). 


\section{Appendix \\ DETAILS OF THE CALCULATION OF EXPERIMENTAL PARAMETERS}

Flux Monitor Analysis

The flux monitor wires irradiated in the $\mathrm{H}-1$ and $\mathrm{H}-2$ capsules were analyzed to determine the thermal and fast flux levels during the irradiation. Measurements of activity were made for the flux monitor reactions given in Table A-1. The ${ }^{59} \mathrm{Fe}$ activity was a measure of the thermal flux during the last cycle, whereas the ${ }^{60} \mathrm{Co}$ activity in the stainless steel wires was a measure of the average thermal flux over all cycles of the test. Similarly, the ${ }^{46} \mathrm{Sc}$ activity was a measure primarily of the fast flux during the last cycle, and the ${ }^{60} \mathrm{Co}$ activity in the nickel wires was a measure of the average fast flux over the whole test. The thermal and fast fluxes were calculated from the measured flux monitor activities with the XSDRN computer code to determine the effective cross sections of the fission monitor reactions. The thermal and fast fluxes measured outside the capsules by ETR personnel were based on the ${ }^{59} \mathrm{Co}(n, \gamma){ }^{60} \mathrm{Co}$ and ${ }^{58} \mathrm{Ni}(n, p){ }^{58}$ Co reactions, respectively.

\section{${ }^{235}$ U Fission Rates}

The ${ }^{235} \mathrm{U}$ fission rates were measured in the ETR Critical Facility at three axial positions with the mockup capsules in their proper orientations and with the ETR core in the configuration existing during cycles 112 and 114. These measured ${ }^{235} \mathrm{U}$ fission rates are given in Table A-2. The ${ }^{235} \mathrm{U}$ fission rates at the other axial positions were inferred from the axial profiles of the thermal flux measured at three radial positions just outside the capsules by ETR personnel during each irradiation cycle. We assumed that the ${ }^{235} \mathrm{U}$ fission rate in a fuel sample was proportional to the thermal flux measured outside the capsule adjacent to the sample. A different proportionality constant was assumed for the $100 \% \mathrm{Hf}$ and $\mathrm{Zr}-40 \% \mathrm{Hf}$ shroud regions. The proportionality constants were determined by setting the ${ }^{235} \mathrm{U}$ fission rates at the fission monitor positions equal to the fission rates measured in the ETR Critical Facility (adjusted to reactor power level) for the irradiation period before the capsules were inverted. More specifically, we assumed that

$$
\left(\sigma_{f}^{25} \phi\right)_{N}(z)=\frac{\left(\sigma_{f}^{25} \phi\right)_{E}(1)}{\phi_{A}\left(z_{1}\right)} \phi_{N}(z)=\frac{\left(\sigma_{f}^{25} \phi\right)_{E}(5)}{\phi_{A}\left(z_{5}\right)} \phi_{N}(z), \quad N=A \text { or } B
$$

for $z$ in the $100 \% \mathrm{Hf}$ shroud region, and

$$
\left(\sigma_{f}^{25} \phi\right)_{N}(z)=\frac{\left(\sigma_{f}^{25} \phi\right)_{E}(9)}{\phi_{A}\left(z_{9}\right)} \phi_{N}(z), \quad N=A \text { or } B
$$

Table A-1. Flux monitor reactions

\begin{tabular}{llll}
\hline \multicolumn{1}{c}{ Monitor wire } & \multicolumn{1}{c}{ Reaction } & Half-life & Neutron energy (MeV) \\
\hline $\begin{array}{l}\text { Fe, type 302 stainless } \\
\text { steel }\end{array}$ & ${ }^{58} \mathrm{Fe}(n, \gamma){ }^{59} \mathrm{Fe}$ & 45 days & Thermal \\
Type 302 stainless steel & ${ }^{59} \mathrm{Co}(n, \gamma){ }^{60} \mathrm{Co}$ & 5.24 years & Thermal \\
$\mathrm{Fe}$, stainless steel & ${ }^{54} \mathrm{Fe}(n, p){ }^{54} \mathrm{Mn}$ & 312 days & $>1.1$ \\
$\mathrm{Ni}$ & ${ }^{60} \mathrm{Ni}(n, p){ }^{60} \mathrm{Co}$ & 5.24 years & $>2.0$ \\
$\mathrm{Ti}$ & ${ }^{46} \mathrm{Ti}(n, p){ }^{46} \mathrm{Sc}$ & 83.8 days & $>2.5$ \\
\hline
\end{tabular}


Table A-2. Fission rates derived from measurements in the ETR Critical Facility

\begin{tabular}{|c|c|c|c|c|c|c|}
\hline \multirow{2}{*}{$\begin{array}{l}\text { Fission monitor } \\
\text { location }\end{array}$} & \multirow{2}{*}{$\begin{array}{c}\text { Shroud } \\
\text { composition }\end{array}$} & \multicolumn{3}{|c|}{$\begin{array}{l}\text { Measured fission rate } \\
\left(\mathrm{kW} \text { per gram of }{ }^{235} \mathrm{U}\right)\end{array}$} & \multirow{2}{*}{$\begin{array}{c}\begin{array}{c}\text { Measured initial } \\
\text { linear heat rate }\end{array} \\
(\mathrm{kW} / \mathrm{ft})\end{array}$} & \multirow{2}{*}{$\left(\frac{\begin{array}{c}\text { Fission rate } \\
235 \\
\text { U fissions }\end{array}}{\sec ^{235} \text { U atom }}\right)$} \\
\hline & & Cycle 112 & Cycle 114 & Average & & \\
\hline $\begin{array}{l}\text { HC-1-1 } \\
\text { HC-2-1 }\end{array}$ & $\begin{array}{l}\text { Hf } \\
\text { Hf }\end{array}$ & $\begin{array}{l}2.59 \\
2.54\end{array}$ & $\left.\begin{array}{l}3.42 \\
2.97\end{array}\right\}$ & 2.88 & 6.6 & $3.90 \times 10^{-8}$ \\
\hline $\begin{array}{l}\text { HC-1-5 } \\
\text { HC-2-5 }\end{array}$ & $\begin{array}{l}\text { Hf } \\
\text { Hf }\end{array}$ & $\begin{array}{l}3.69 \\
3.72\end{array}$ & $\left.\begin{array}{l}4.05 \\
3.87\end{array}\right\}$ & 3.83 & 8.8 & 5.18 \\
\hline $\begin{array}{l}\text { HC-1-9 } \\
\text { HC-2-9 }\end{array}$ & $\begin{array}{l}\mathrm{Z}_{\mathrm{r}-40 \% \mathrm{Hf}} \\
\mathrm{Z}_{\mathrm{r}-40 \% \mathrm{Hf}}\end{array}$ & $\begin{array}{l}3.27 \\
3.44\end{array}$ & $\left.\begin{array}{l}3.96 \\
3.87\end{array}\right\}$ & 3.64 & 8.4 & 4.93 \\
\hline
\end{tabular}

${ }^{a}$ Assuming $180 \mathrm{MeV}$ deposited in fuel samples per fission, excluding gamma heating.

${ }^{b}\left(\frac{\mathrm{kW}}{\mathrm{ft}}\right)=\left(\frac{\mathrm{kW}}{\mathrm{g}^{235} \mathrm{U}}\right) \times\left(\frac{0.191 \mathrm{~g}^{235} \mathrm{U}}{\text { in. }}\right) \times\left(\frac{12 \mathrm{in}}{\mathrm{ft}}\right)=2.29 \times\left(\frac{\mathrm{kW}}{\mathrm{g}^{235} \mathrm{U}}\right)=$ linear fission heat rate.

$$
\begin{aligned}
c\left(\frac{\text { fissions }}{\sec ^{235} \mathrm{U} \text { atom }}\right) & =\left(\frac{\mathrm{kW}}{\mathrm{g}^{235} \mathrm{U}}\right) \times\left(\frac{1 \mathrm{fission}}{180 \mathrm{MeV}}\right) \times\left(\frac{6.24 \times 10^{15} \mathrm{MeV}}{\mathrm{kW} \mathrm{sec}}\right) \times\left(\frac{235 \mathrm{~g}^{235} \mathrm{U}}{\mathrm{mole}}\right) \times\left(\frac{1 \mathrm{~mole}}{6.02 \times 10^{23} \text { atoms }}\right) \\
& =1.35 \times 10^{-8} \times\left(\frac{\mathrm{kW}}{\mathrm{g}^{235} \mathrm{U}}\right)
\end{aligned}
$$

for $z$ in the $\mathrm{Zr}-40 \% \mathrm{Hf}$ shroud region, where $A$ denotes the irradiation period before the capsule inversion, $B$ denotes the irradiation period after the capsule inversion,

$$
\begin{aligned}
z= & \text { axial position in the ETR core, } \\
z_{i}= & \text { axial position of the midplane of sample } i, \\
\phi_{A}\left(z_{i}\right)= & \text { thermal flux }(2200 \mathrm{~m} / \mathrm{sec}) \text { measured outside the capsules at the position of rod } i \text { before } \\
& \text { the capsule inversion, } \\
\phi_{N}(z)= & \text { thermal flux measured at axial position } z \text { outside the capsules before }(N=A) \text { or after }(N \\
& =B) \text { the capsules were inverted, } \\
\left(\sigma_{f}{ }^{25} \phi\right)_{N}(z)= & { }^{235} \mathrm{U} \text { fission rate before or after capsule inversion at axial position } z, \text { in fissions per } \\
& \text { second per }{ }^{235} \mathrm{U} \text { atom, } \\
\left(\sigma_{f}{ }^{25} \phi\right)_{E}(\mathrm{i})= & { }^{235} \mathrm{U} \text { fission rate (corrected to reactor power) measured in the ETR Critical Facility at } \\
& \text { rod } i \text { before the capsules were inverted. }
\end{aligned}
$$

The axial profile of ${ }^{235} \mathrm{U}$ fission rate determined in this manner is shown in Fig. A-1 before and after the capsules were inverted.

As a check on this method of normalization, the axial profile of ${ }^{235} \mathrm{U}$ fission rate was estimated from the unperturbed axial thermal flux profile measured at the J.8 position of the ETR core during cycle 107B, as shown in Fig. A-2. For a particular unperturbed thermal flux level, XSDRN calculations show that the ${ }^{235} \mathrm{U}$ fission rate in a sample surrounded by a $\mathrm{Zr}-40 \% \mathrm{Hf}$ shroud is 1.48 times the fission rate in a sample surrounded by a $100 \% \mathrm{Hf}$ shroud. The axial profile of ${ }^{235} \mathrm{U}$ fission rate can then be estimated by multiplying the unperturbed flux profile shown in Fig. A-2 by 1.48 for the fuel samples surrounded by the $\mathrm{Zr}-40 \% \mathrm{Hf}$ shroud while keeping the profile in the $100 \% \mathrm{Hf}$ region constant. This estimated profile of ${ }^{235} \mathrm{U}$ fission rate is also shown in Fig. A-1 and has been normalized to the ${ }^{235} \mathrm{U}$ fission rate measured at rod 5 in the ETR Critical Facility. The equations used in deriving this approximate axial profile of ${ }^{235} \mathrm{U}$ 
ORNL-DWG 73-11137

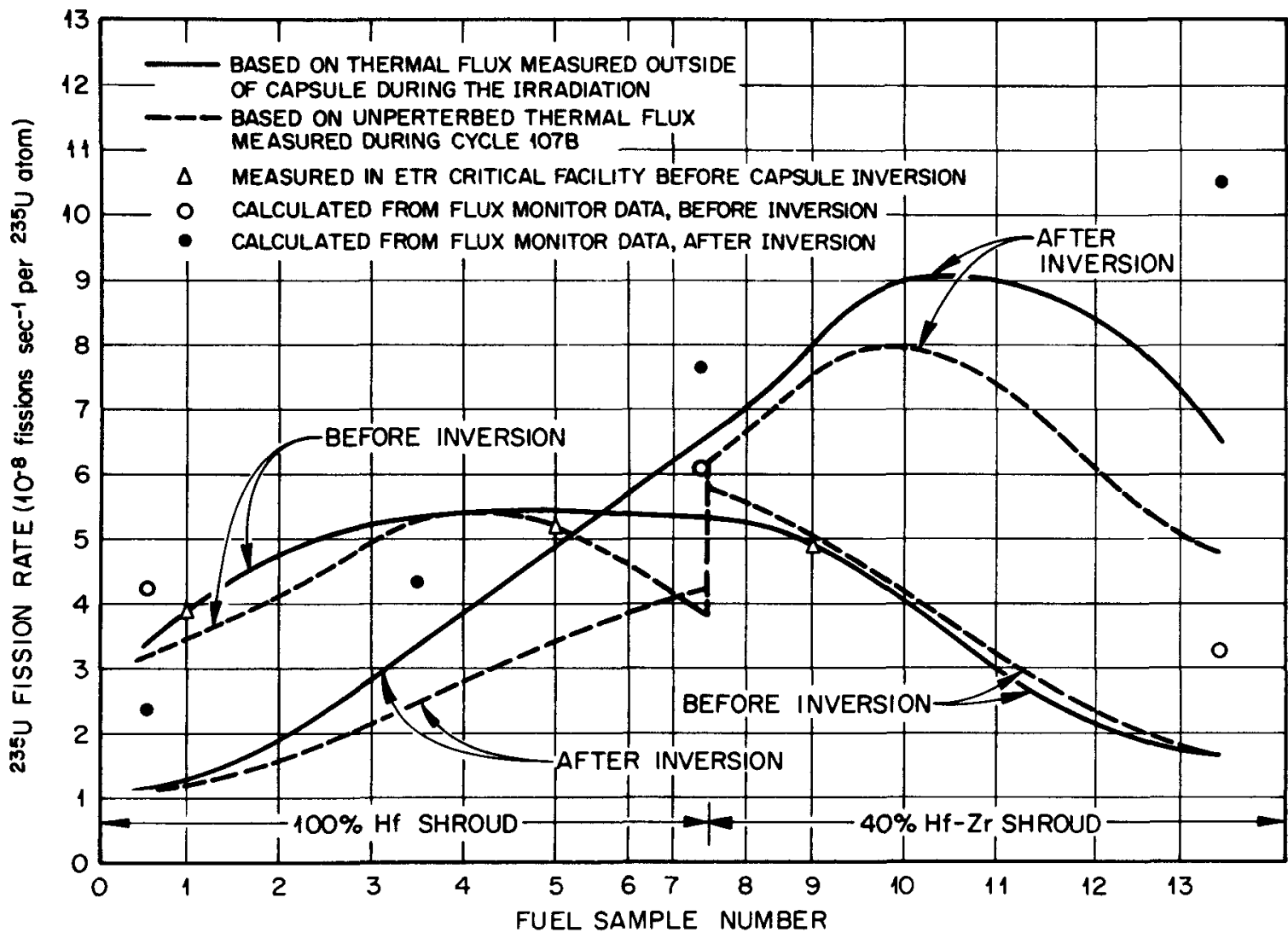

Fig A-1. Fission rates of ${ }^{235} \mathrm{U}$ before and after capsule inversion.

ORNL-OWG 73-14138

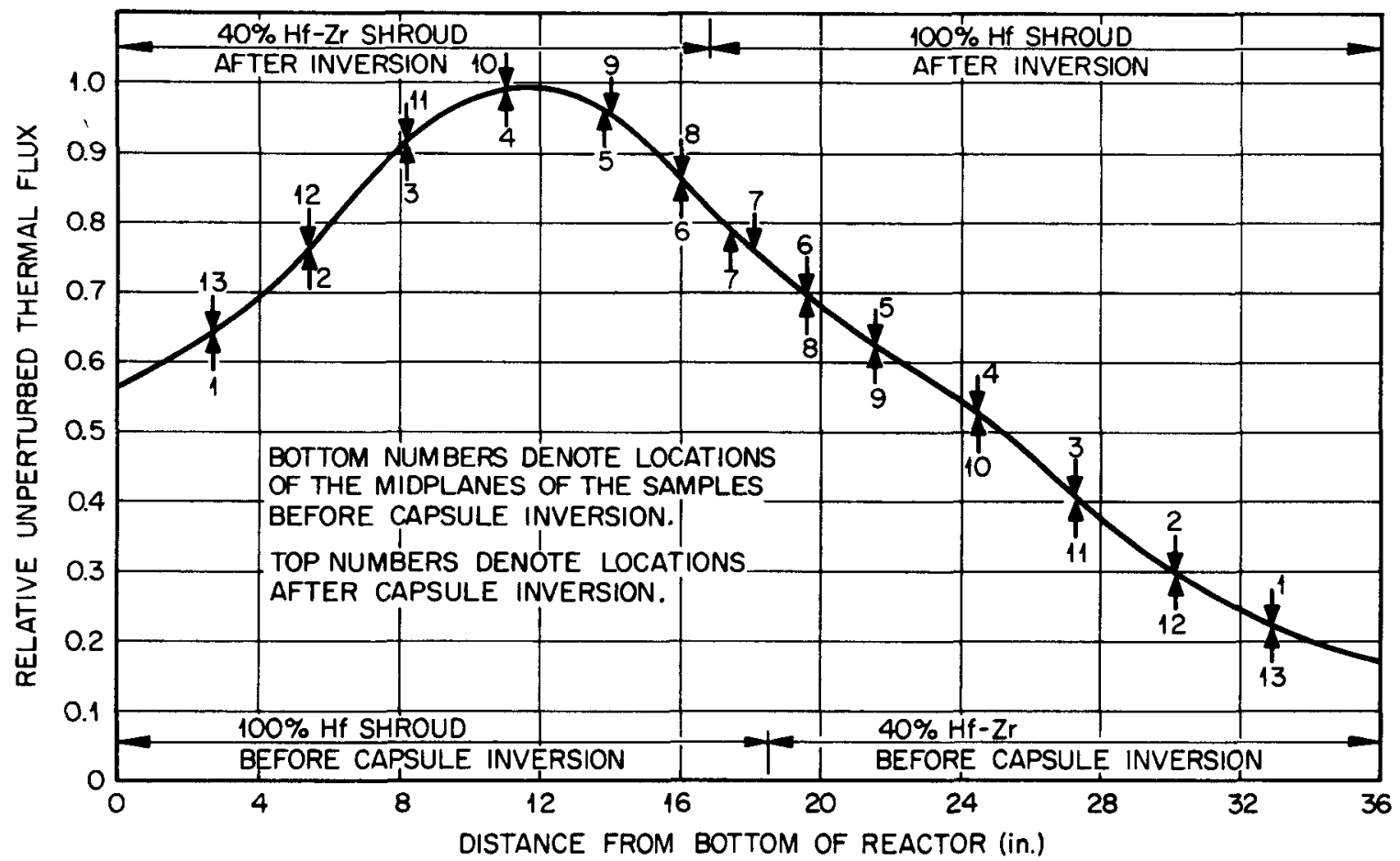

Fig. A-2. Axial profile of unperturbed thermal flux measured during ETR cycle 107B. 
fission rate were:

$$
\left(\sigma_{f}^{25} \phi\right)_{N}(z)=\frac{\left(\sigma_{f}^{25} \phi\right)_{E}(5)}{\phi_{u}^{A}\left(z_{5}\right)} \phi_{u}(z), \quad N=A, B
$$

for $z$ in the $100 \% \mathrm{Hf}$ shroud region, and

$$
\left(\sigma_{f}^{25} \phi\right)_{N}(z)=1.48 \frac{\left(\sigma_{f}^{25} \phi\right)_{E}^{(5)}}{\phi_{u}^{A}\left(z_{5}\right)} \phi_{u}(z), \quad N=A, B,
$$

for $z$ in the $40 \% \mathrm{Hf}$ shroud region, where

$\phi_{u}(z)=$ unperturbed thermal flux $(2200 \mathrm{~m} / \mathrm{sec})$ measured during cycle 107B,

$\phi_{u} A\left(z_{5}\right)=$ unperturbed thermal flux at the axial position of rod 5 before the capsules were inverted.

As shown in Fig. A-1 and Table A-3, the axial profiles of ${ }^{235} \mathrm{U}$ fission rates as determıned by these methods are in reasonably good agreement before the capsules were inverted but differ by approximately $25 \%$ after the capsule inversion. The profiles determined from the unperturbed flux measured during cycle 107B are less reliable than those determined from the thermal flux measured outside the capsules because (1) the shape of the unperturbed flux profile is not necessarily the same as that of the source of thermal neutrons that enter the capsules because of perturbations by the strongly absorbing hafnium shrouds and by the adjacent control rods, which were in different positions when the capsules were in the reactor than when the capsules were absent; (2) the discontinuity of fission rate at the center of the capsules is unreasonable because the neutron flux varies much more slowly than the macroscopic neutron absorption cross section between the two shroud regions; and (3) the level of the source neutrons is not necessarily the

Table A-3. Comparison of ${ }^{235} \mathrm{U}$ fission rate as determined from flux monitor analysis and as calculated from

\begin{tabular}{|c|c|c|c|c|c|}
\hline \multirow{3}{*}{$\begin{array}{l}\text { Location of } \\
\text { flux monitor }\end{array}$} & \multirow{2}{*}{\multicolumn{3}{|c|}{$\begin{array}{c}{ }^{235} \mathrm{U} \text { fission rate } \\
\text { [fissions sec }{ }^{-1}\left({ }^{235} \mathrm{U} \text { atom }\right)^{-1} \text { ] }\end{array}$}} & \multicolumn{2}{|c|}{ Ratio } \\
\hline & & & & \multirow{2}{*}{$\frac{\text { Monitor }}{\text { Outside }}$} & \multirow{2}{*}{$\frac{107 \mathrm{~B}}{\text { Outside }}$} \\
\hline & Outside $^{a}$ & $107 \mathrm{~B}^{b}$ & Monitor ${ }^{c}$ & & \\
\hline \multicolumn{6}{|c|}{ Before capsules were inverted } \\
\hline Top & $1.6 \times 10^{-8}$ & $1.6 \times 10^{-8}$ & $3.27 \times 10^{-8}$ & 2.04 & 1.0 \\
\hline Center & 5.3 & 3.9 & 6.10 & 1.15 & 0.74 \\
\hline Between rods 3 and 4 & 5.4 & 5.3 & & & 0.98 \\
\hline Bottom & 3.4 & 3.2 & 4.24 & 1.25 & 0.94 \\
\hline \multicolumn{6}{|c|}{ After capsules were inverted } \\
\hline Top & 6.5 & 4.8 & 10.5 & 1.62 & 0.74 \\
\hline Center & 6.5 & 4.2 & 7.66 & 1.18 & 0.65 \\
\hline Between rods 3 and 4 & 3.3 & 2.5 & 4.32 & 1.31 & 0.76 \\
\hline Bottom & 1.2 & 1.1 & 2.34 & 1.95 & 0.92 \\
\hline
\end{tabular}
ETR Critical Facility measurements

${ }^{a_{F}}$ Fission rate of ${ }^{235} \mathrm{U}$ based on ETR Critical data using the thermal flux profiles measured outside the capsules.

${ }^{b}$ Fission rate of ${ }^{235} \mathrm{U}$ based on ETR Critical data using the thermal flux profile measured during cycle $107 \mathrm{~B}$.

$c_{\text {Fission rate of }}{ }^{235} \mathrm{U}$ determined from flux monitor analysis. 
same after the capsule inversion as before, as was assumed in Eq. (A-2). In fact, the neutron source strength apparently was approximately $25 \%$ larger after the capsules were inverted than before, as can be seen by comparing the profile after inversion based on the flux measured outside the capsules with the profile after inversion based on the unperturbed flux.

The ${ }^{235} \mathrm{U}$ fission rates before and after the capsule inversion as determined from the analysis of the flux monitors are shown in Table A-3 and Fig. A-1. As shown in Table A-3, the fission rates determined from flux monitor analysis are from 15 to 104\% larger than the values based on the ETR Critical Facility normalization. The ${ }^{235} \mathrm{U}$ fission rates at the flux monitor positions were estimated from the flux monitor data by multiplying the measured thermal flux monitor reaction rates by the ratio of ${ }^{235} \mathrm{U}$ fission cross section to the neutron activation cross sections of the thermal flux monitors, as calculated with the XSDRN code. The fission rate profiles based on the thermal fluxes measured outside the capsules during cycles 112 through 115 (and normalized to the ETR Critical Facility data) are considered more reliable than those estimated from the flux monitor data because the ${ }^{235} \mathrm{U}$ fission rates were measured directly in the ETR Critical Facility. The fission rates estimated from the flux monitor data are probably in error because of the difficulty in calculating the effect of the hafnium-zirconium shrouds on the ratio of ${ }^{235} \mathrm{U}$ fission cross section to the neutron activation cross sections of the thermal flux monitors.

\section{Reaction Rates of Other Fuel Isotopes}

The fission and neutron absorption rates in the various fuel isotopes were calculated with the XSDRN code. The reaction rates relative to the ${ }^{235} \mathrm{U}$ fission rate in a fuel sample surrounded by a $100 \% \mathrm{Hf}$ shroud are given in Table A-4. These values are for a constant neutron source with an energy spectrum characteristic of the ETR core. The actual reaction rates at full power used in solving the nuclear transformation equations are related to the relative reaction rates by:

$$
\left(\sigma_{i} \phi\right)=\frac{\left(\sigma_{f}^{25} \phi\right)}{\left(\sigma_{f}^{25} \phi\right)_{\mathrm{rel}}} \times\left(\sigma_{i} \phi\right)_{\mathrm{rel}}
$$

Table A-4. Relative ${ }^{a}$ fission and neutron absorption rates as calculated by XSDRN

\begin{tabular}{|c|c|c|c|c|}
\hline \multirow[t]{2}{*}{ Isotope } & \multicolumn{2}{|c|}{$\begin{array}{l}\text { Relative reaction rate } \\
\text { in fuel surrounded by } \\
100 \% \text { Hf shroud }\end{array}$} & \multicolumn{2}{|c|}{$\begin{array}{l}\text { Relative reaction rate } \\
\text { in fuel surrounded by } \\
\mathrm{Zr}-40 \% \mathrm{Hf} \text { shroud }\end{array}$} \\
\hline & $\begin{array}{c}\text { Neutron capture } \\
\text { rate }\left(\sigma_{c} \phi\right)\end{array}$ & $\begin{array}{l}\text { Fission rate } \\
\left(\sigma_{f} \phi\right)\end{array}$ & $\begin{array}{l}\text { Neutron capture } \\
\text { rate }\left(\sigma_{c} \phi\right)\end{array}$ & $\begin{array}{l}\text { Fission rate } \\
\left(\sigma_{f} \phi\right)\end{array}$ \\
\hline${ }^{232} \mathrm{Th}$ & 0.033 & 0.0 & 0.042 & 0.0 \\
\hline${ }^{233} \mathrm{~Pa}$ & 0.310 & 0.0 & 0.415 & 0.0 \\
\hline${ }^{233} \mathrm{U}$ & 0.117 & 1.084 & 0.164 & 1.565 \\
\hline${ }^{234} \mathrm{U}$ & 0.229 & 0.0 & 0.373 & 0.0 \\
\hline${ }^{235} \mathrm{U}$ & 0.212 & 1.0 & 0.300 & 1.476 \\
\hline${ }^{236} \mathrm{U}$ & 0.014 & 0.0 & 0.025 & 0.0 \\
\hline${ }^{238} \mathrm{U}$ & 0.084 & 0.0 & 0.103 & 0.0 \\
\hline${ }^{239} \mathrm{~Np}$ & 0.107 & 0.0 & 0.160 & 0.0 \\
\hline${ }^{239} \mathrm{Pu}$ & 0.714 & 1.61 & 0.996 & 2.29 \\
\hline
\end{tabular}

${ }^{a}$ Relative to the ${ }^{235} \mathrm{U}$ fission rate in fuel surrounded by $100 \% \mathrm{Hf}$ shroud. 
where

$\left(\sigma_{i} \phi\right)=$ actual reaction rate for process $i$, in number of reactions of type $i$ per second per reacting nucleus at full reactor power,

$\left(\sigma_{i} \phi\right)_{\mathrm{rel}}=$ relative reaction rate for process $i$, given in Table A-4,

$\left(\sigma_{f}^{25} \phi\right)=$ actual $^{235} \mathrm{U}$ fission rate, solid curves in Fig. A-1,

$\left(\sigma_{f}^{25} \phi\right)_{\text {rel }}=$ relative ${ }^{235} U$ fission rate, from Table A-4.

The reaction rates determined in this manner were used to calculate the fuel composition, total fission heat rate, and heavy metal burnup in all fuel samples during each irradiation cycle. 


\section{ORNL-TM-4397 \\ UC-77 - Gas-Cooled Reactor Technology}

INTERNAL DISTRIBUTION

(165 copies)

R. L. Beatty

E. S. Bettis (consultant)

R. A. Bradley

A. J. Caputo

J. M. Chandler

T. E. Cole

J. A. Conlin

J. H. Coobs

D. A. Costanzo

J. E. Cunningham

H. J. de Nordwall

F. F. Dyer

W. P. Eatherly

R. B. Evans III

J. I. Federer

D. E. Ferguson

(2) R. B. Fitts

C. L. Fitzgerald

R. J. Gray

P. A. Haas

R. L. Hamner

(3) M. R. Hill

F. J. Homan

J. D. Jenkins

M. J. Kania

(38) P. R. Kasten

H. T. Kerr

E. M. King

W. J. Lackey, Jr.

(15) T. B. Lindemer

(5) E. L. Long, Jr.
A. L. Lotts
R. S. Lowrie
R. E. McPherson

A. P. Malinauskas

W. R. Martin

B. H. Montgomery

H. C. McCurdy

M. T. Morgan

K. J. Notz

(2) A. R. Olsen

(15) R. A. Olstad

M. F. Osborne

R. B. Parker

P. Patriarca

R. L. Pearson

W. H. Pechin

H. Postma

M. K. Preston

P. L. Rittenhouse

J M Robbins

J. L. Scott

J. D. Sease

G. M. Slaughter

J. W. Snider

K. R. Thoms

D. B. Trauger

K. H. Valentine

J. E. Van Cleve

V.C. A. Vaughen

T. N. Washburn

J. R. Weir, Jr.

(3) Central Research Library ORNL - Y-12 Technical Library Document Reference Section

(5) Laboratory Records Department Laboratory Records, ORNL R.C. ORNL Patent Office 


\section{Subcontractors and Consultants}

Brookhaven National Laboratory, Upton, Long Island, NY 11973 HTGR Program Manager

Consulting Engineer George V. Smith, 104 Berkshire Road, Ithaca, NY 14850

Gulf General Atomic, P.O. Box 81608, San Diego, CA 92138

W. E. Bell

L. H. Brooks

R. C. Dahlberg

W. V. Goeddel

T. Gulden

D. P. Harmon

C. A. Heath

R. E. Norman

C. B. Scott

O. M. Stansfield

H. B. Stewart

R. F. Turner

Lawrence Radiation Laboratory, University of California, Inorganic Materials Research Division, Berkeley, CA 94720

Leo Brewer

Los Alamos Scientific Laboratory, Los Alamos, NM 87544

William Kirk, P.O. Box 1663

Paul Wagner, Bldg. CMB-8

University of California, San Diego, Department of Physics, Revelle College, P.O. Box 109, La Jolla, CA 92037 Walter Kohn

University of Illinois, Department of Physics, Urbana, IL 61801

Wendell S. Williams

\section{EXTERNAL DISTRIBUTION}

(155 copies)

USAEC DIVISION OF REACTOR RESEARCH AND DEVELOPMENT, Washington, DC 20545

Director

USAEC-RRD SENIOR SITE REPRESENTATIVE, Oak Ridge National Laboratory, Oak Ridge, TN 37830

USAEC OAK RIDGE OPERATIONS OFFICE, P.O. Box E, Oak Ridge, TN 37830

Research and Technical Support Division

For distribution as shown in TID-4500 Distribution Category, UC-77, Gas-Cooled Reactor Technology (25 copies - NTIS) 